\title{
Orchidaceae na Serra do Ouro Branco, Minas Gerais, Brasil
}

Orchidaceae from Serra do Ouro Branco, state of Minas Gerais, Brazil

\author{
Tiago Luiz Vieira ${ }^{1,2,3}$ \& Fábio de Barros ${ }^{2}$
}

\begin{abstract}
Resumo
A Serra do Ouro Branco demarca o limite sul da Cadeia do Espinhaço, em Minas Gerais, e está situada em uma zona de transição entre os domínios Atlântico e do Cerrado. O objetivo deste estudo foi realizar o levantamento florístico da família Orchidaceae na Serra do Ouro Branco, município de Ouro Branco, Minas Gerais, Brasil. Foram registrados 36 gêneros e 75 espécies para a área. Os gêneros mais representativos foram Habenaria (17 spp.), Cleistes (7 spp.), Acianthera e Epidendrum (6 spp. cada). A elevada riqueza de Orchidaceae em uma área relativamente pequena evidencia a importância florística da família em si e, também, a relevância ambiental da área de estudo. São apresentadas chaves de identificação, descrições, ilustrações esquemáticas das peças do perianto, e comentários sobre os gêneros e espécies.

Palavras-chave: Cadeia do Espinhaço, campo rupestre, florística, orquídeas, taxonomia.
\end{abstract}

\begin{abstract}
The Serra do Ouro Branco delimitates the southern geographical boundary of the Espinhaço Range, in the state of Minas Gerais, and is located in a transition zone between the Atlantic Forest and Cerrado domains. This paper presents the floristic survey of the Orchidaceae from Serra do Ouro Branco, municipality of Ouro Branco, state of Minas Gerais, Brazil. We recorded 36 genera and 75 species in the study area. The most representative genera were Habenaria (17 spp.), Cleistes ( 7 spp.), Acianthera and Epidendrum (6 spp. each). Such elevated richness in a relatively small area, highlights the floristic significance of Orchidaceae and the environmental relevance of the study area. Identification keys, morphological descriptions, schematic illustrations of the perianth, and comments of the genera and species are presented.
\end{abstract}

Key words: Espinhaço Range, rocky outcrops, floristic treatment, orchids, taxonomy.

\section{Introdução}

Orchidaceae Juss. compreende aproximadamente 24.500 espécies distribuídas em 800 gêneros (Dressler 1993; Cribb 1999; Dressler 2005), trata-se de uma das maiores famílias dentre as angiospermas e a maior dentre as monocotiledôneas. Seu centro de diversidade é a região tropical, principalmente as áreas montanhosas cobertas por florestas na região neotropical e no sudeste asiático (Dressler 1981, 1993). Para o Brasil, atualmente, são reconhecidas cerca de 2.500 espécies e 238 gêneros. A Floresta Atlântica é o domínio fitogeográfico com maior riqueza, seguido da Amazônia e do Cerrado (BFG 2015).
Minas Gerais é o estado brasileiro com maior riqueza de orquídeas: 945 espécies e 155 gêneros (BFG 2015). A grande extensão territorial, abrangendo parte dos domínios Atlântico, Cerrado e Caatinga, associada ao relevo acidentado com muitos complexos montanhosos e grande variação altitudinal, acarreta em grande heterogeneidade de formações vegetacionais e tipos de habitats. Além disso, a flora do estado tem sido objeto de coletas e estudos contínuos desde a vinda dos naturalistas europeus no século XIX (e.g., Saint-Hilaire 18161822 e Spix \& Martius 1817-1820).

No estado, uma região que merece destaque, em se tratando de diversidade florística, é a Serra do Espinhaço, que conjuntamente com a Chapada

\footnotetext{
${ }^{1}$ Instituto de Botânica, Prog. Pós Graduação em Biodiversidade Vegetal e Meio Ambiente, Av. Miguel Stefano 3687, Água Funda, 04045-972, São Paulo, SP, Brasil.

${ }^{2}$ Instituto de Botânica, Núcleo de Pesquisa Orquidário do Estado, Av. Miguel Stefano 3687, Água Funda, 04045-972, São Paulo, SP, Brasil.

${ }^{3}$ Autor para correspondência: tiagolvs@gmail.com
} 
Diamantina, na Bahia, constitui a Cadeia do Espinhaço, uma cadeia de serras com formações predominantemente quartzíticas que se estende na direção norte-sul, entre a Bahia e Minas Gerais, com altitudes que variam desde os 700 até os $2.000 \mathrm{~m}$ acima do nível do mar (Giulietti \& Pirani 1988; Harley 1995). A origem da formação deu-se no Pré-Cambriano e, ainda no Terciário, sofreu alguns processos de remodelamento em virtude da dinâmica da tectônica de placas no período, além do contínuo processo de erosão; este conjunto de fatores culminou nessa formação antiga, com uma flora relictual, em muitos casos, em meio a uma paisagem de platôs descontínuos, com alguns picos, onde predominam as rochas metassedimentares (Giulietti \& Pirani 1988).

A fitofisionomia característica da região é o campo rupestre: vegetação aberta, de altitude, sobre solos rasos, ácidos, em meio a afloramentos rochosos, onde há predomínio dos extratos herbáceo e arbustivo, e as plantas são adaptadas a condições de estresse hídrico, solos pobres e intensa exposição à radiação solar, havendo uma grande diversidade florística e muitos endemismos (Harley 1995; Rapini et al. 2008). Os campos rupestres abrigam cerca de $11 \%$ da diversidade de angiospermas para o Brasil (BFG 2015), embora ocupem uma área consideravelmente pequena em relação à extensão territorial do país, o que evidencia sua importância florística e, portanto, a necessidade de conhecer sua flora e conservá-la.

$\mathrm{Na}$ Serra do Espinhaço, além da presença dos campos rupestres, outro fator que contribui para a elevada diversidade florística é a influência da Floresta Atlântica, já que o sul da cadeia se encontra na área de transição entre os domínios Atlântico e do Cerrado. As formações florestais do espinhaço mineiro apresentam, na sua composição, muitas espécies típicas da Floresta Atlântica, sobretudo na porção sul, desde a Serra do Cipó até a Serra do Ouro Branco e imediações (Harley 1995; Kamino et al. 2008). A UNESCO (2005) declarou a Serra do Espinhaço como Reserva da Biosfera, dada a relevância de seus atributos biológicos e físicos.

Uma quantidade considerável de estudos florísticos com Orchidaceae vêm sendo realizados ao longo da Cadeia do Espinhaço e demais áreas montanhosas de Minas Gerais, tanto no contexto de grandes floras fanerogâmicas como em estudos isolados da família, e estes, em geral, evidenciam a riqueza e relevância florística da família para a região devido ao número elevado de gêneros e espécies (Harley \& Simmons 1986; Barros 1987;
Alves 1990; Pirani et al. 1994; Toscano de Brito 1995, 1998a, 1998b; Toscano de Brito \& Queiroz 2003; Barros \& Pinheiro 2004; Leoni \& Tinte 2004; Hatschbach et al. 2006; Mota 2006; Azevedo \& Van den Berg 2007; Menini Neto et al. 2007; Alves \& Kolbek 2009; Abreu et al. 2011; Bastos \& Van den Berg 2012; Vieira et al. 2014).

A Serra do Ouro Branco (SOB) (Fig. 1) constitui o limite sul da Cadeia do Espinhaço (Harley 1995) e encontra-se na zona de transição entre os domínios fitogeográficos Cerrado e Atlântico, como já comentado. Mais precisamente, a SOB está inserida no Quadrilátero Ferrífero, uma área de aproximadamente $7.000 \mathrm{~km}^{2}$ na porção centro-sudeste de Minas Gerais, que corresponde ao extremo sul da Serra do Espinhaço e, consequentemente, da Cadeia do Espinhaço, onde há uma elevada concentração de minério de ferro nas formações rochosas da região (Azevedo 2007). Tal característica acarreta condições edáficas particulares à região, com as áreas de afloramentos sendo denominadas de "cangas" e apresentando uma flora particular, logo, a região do Quadrilátero Ferrífero apresenta um mosaico de tipos de vegetação de afloramentos rochosos: os campos rupestres de formações quartzíticas e os campos rupestres ferruginosos, em formações ricas em minério de ferro (Rizini 1979; Viana \& Lombardi 2007). A biodiversidade da região encontra-se sob constante ameaça devido à intensa atividade das empresas de mineração, enquanto as políticas públicas, como a proposta de unidades de conservação, ainda são escassas.

A SOB passou a ser alvo de estudos florísticos sistematizados após o início do projeto "Flora fanerogâmica da Serra do Ouro Branco" realizado pelo Departamento de Biologia Vegetal da Universidade Federal de Viçosa (UFV), sob coordenação do Prof. Dr. Cláudio Coelho de Paula. Foram realizadas coletas entre os anos de 2002 a 2006 e, até o momento, foram publicadas uma caracterização da área (Paula et al. 2005) e as floras das famílias Myrtaceae (Santos \& Sano 2012) e Cyperaceae (Longhi-Wagner \& Araújo 2014). Recentemente, em 2009, foi criado e decretado pelo Instituto Estadual de Florestas de Minas Gerais o Parque Estadual da Serra do Ouro Branco, Unidade de Conservação (UC) que abrange toda a área da serra e imediações, entre os municípios de Ouro Branco e Ouro Preto.

Visando dar continuidade aos estudos florísticos na área, o objetivo deste trabalho foi realizar o inventário da família Orchidaceae na 
Serra do Ouro Branco, apresentando descrições, chaves de identificação, ilustrações esquemáticas das peças do perianto, pranchas com fotografias, dados de distribuição geográfica e dos habitats das espécies, bem como comentários taxonômicos.

\section{Material e Métodos}

Área de estudo

A Serra do Ouro Branco, 20²9'23"S $43^{\circ} 42^{\prime} 43^{\prime} \mathrm{W}$, está completamente inserida no município de Ouro Branco, Minas Gerais. Ocupa uma área de aproximadamente 2.750 ha (Paula 2005), está disposta no sentido leste-oeste, com cerca de $18 \mathrm{~km}$ de extensão e apresenta quotas de altitude variando, aproximadamente, desde os 800 até os $1.550 \mathrm{~m}$ acima do nível do mar. O clima da região é do tipo $\mathrm{Cwb}$ segundo a classificação de
Köppen \& Geiger (Alvares et al. 2013), com período chuvoso entre novembro e março e inverno seco. A temperatura média anual é de $20,7^{\circ} \mathrm{C}$ e a precipitação média anual é de 1.188,2 mm (Paula 2005).

$\mathrm{Na}$ porção superior da serra, nas áreas de maior altitude, configura-se um platô onde predominam as fitofisionomias campestres, como os campos rupestres quartzíticos e ferruginosos, com o primeiro tipo ocupando área muito maior, os campos limpos, que cobrem a maior parte das áreas altas da serra, algumas manchas de cerrado s.s., além de áreas de mata, como as matas de galeria associadas aos cursos d'água e alguns capões de mata em locais com solo mais profundo (Fig. 2). No sopé da serra e áreas de encosta ocorrem formações de Floresta Estacional Semidecidual e algumas matas de galeria.

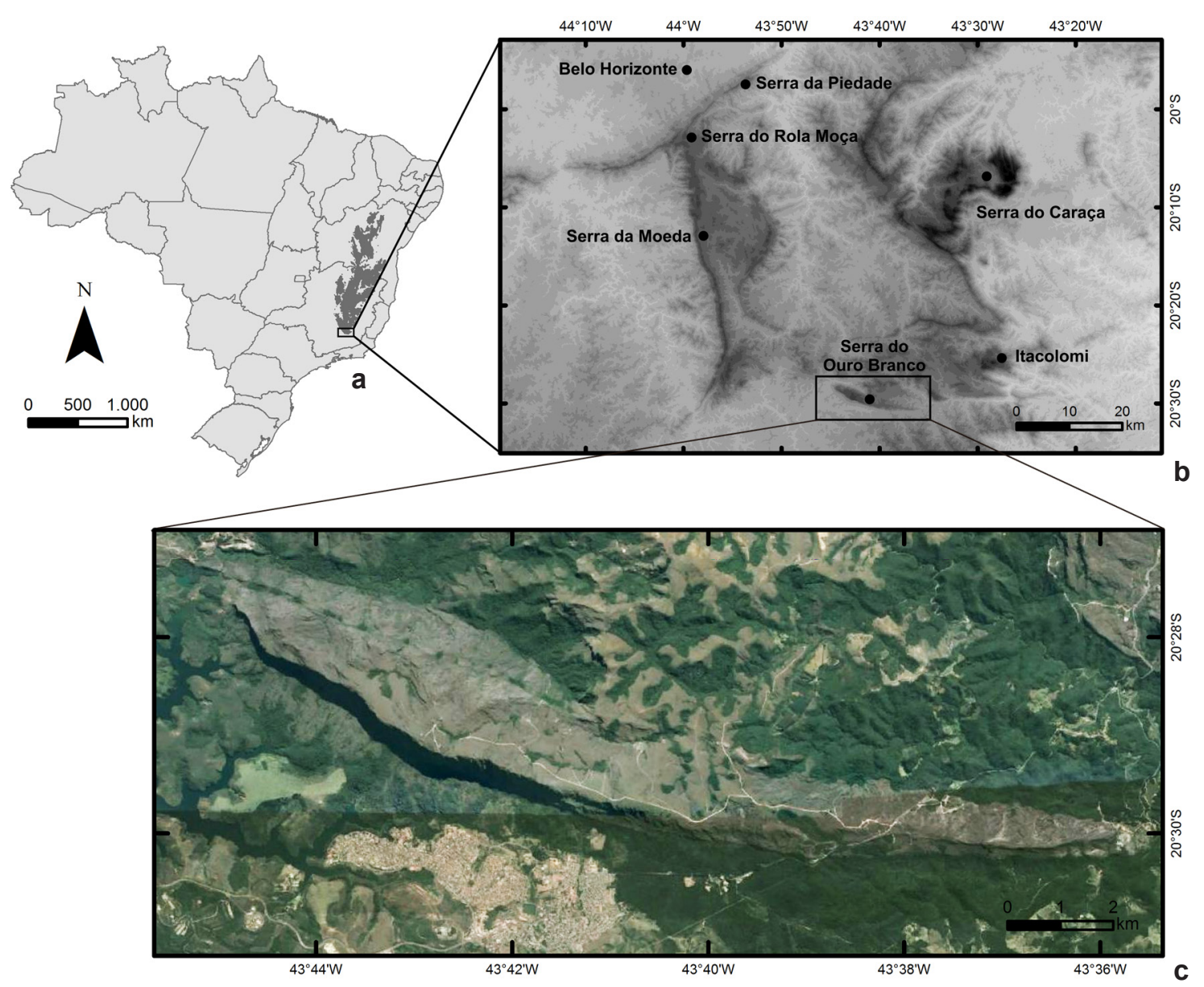

Figura 1 - Localização da Serra do Ouro Branco, Minas Gerais. a. Cadeia do Espinhaço. b. Região do Quadrilátero Ferrífero de Minas Gerais. c. imagem de satélite da Serra do Ouro Branco.

Figure 1 - Location of the Serra do Ouro Branco, Minas Gerais. a. Espinhaço Range. b. Iron Quadrangle region of Minas Gerais. c. satellite image of Serra do Ouro Branco. 
Levantamento florístico

Para dar continuidade às coletas realizadas entre 2002 e 2006 , foram realizadas seis expedições a campo, com duração média de quatro dias cada, contemplando as estações seca e chuvosa, entre setembro de 2013 e janeiro de 2015 , buscando sempre percorrer diferentes tipos de fitofisionomias nas localidades ao longo da serra. Os materiais coletados foram depositados no herbário SP, com envio de duplicatas ao BHCB (acrônimos conforme Thiers, continuamente atualizado) e, quando disponível material, ao VIC e RB. Além do trabalho de campo, foram consultadas as coleções dos herbários BHCB, ESA, ESAL, HB, HUFSJ, MBM, OUPR, R, RB, SP, SPF, VIC, UEC e UPCB. Os materiais referidos como "fl. cult.", no material examinado, são provenientes da coleção do Orquidário do Instituto de Botânica.

\section{Identificação e descrição do material}

Para a identificação dos táxons encontrados foi consultada literatura especializada da família, especialmente: Rodrigues (1877, 1882), Cougniaux (1893-1896, 1898-1902, 1904-1906), Hoehne (1940, 1942, 1945, 1949), Pabst \& Dungs (1975, 1977), Garay (1980), Sprunger (1996), e também os protólogos, sempre que possível, bem como analisados os materiais typi depositados nos herbários visitados ou disponíveis online. Quanto ao sistema de classificação, para as categorias supra-genéricas foi adotado Pridgeon et al. (1999, 2001, 2003, 2005, 2009, 2014), recentemente atualizado por Chase et al. (2015), enquanto a delimitação dos gêneros está de acordo com BFG (2015).

A terminologia morfológica seguiu Dressler (1993) e Radford et al. (1974). Para os gêneros Cleistes, Epistephium, Habenaria e Skeptrostachys foi considerado como pedúnculo da inflorescência o primeiro entrenó anterior à primeira flor disposta na inflorescência. A descrição da morfologia do labelo em todos os gêneros da subtribo Spiranthinae (Eurystyles, Pelexia, Sacoila, Sarcoglottis, Sauroglossum, Stigmatosema e Veyretia), exceto Skeptrostachys, seguiu o padrão de divisão do labelo em hipoquílio e epiquílio.

\section{Resultados e Discussão}

Foram encontradas, na Serra do Ouro Branco, 75 espécies da família Orchidaceae distribuídas em 36 gêneros. Os gêneros com maior representatividade foram Habenaria Willd. (17 spp.), seguido de Cleistes Rich. ex Lindl. (7 spp.), Acianthera Scheidw. e Epidendrum L. (6 spp. cada), Campylocentrum Benth. e Hoffmannseggella H.G.Jones (3 spp. cada), Liparis Rich, Pelexia Poit. ex Lindl. e Prescottia Lindl. (2 spp. cada). Os demais 27 gêneros apresentaram apenas uma espécie cada. Dentre as espécies encontradas, 39 pertencem à subfamília Epidendroideade (52\%), 28 à subfamília Orchidoideae $(37 \%)$ e oito à subfamília Vanilloideae (11\%). Desenhos dos periantos dissecados são apresentados ao longo do tratamento taxonômico e fotografias das espécies nos anexos, ao final do manuscrito, respectivamente.

O fato de Habenaria e Cleistes serem os gêneros mais representativos decorre, certamente, do predomínio de áreas de campo limpo ao longo da paisagem da SOB, fitofisionomia esta característica do domínio do Cerrado. Esses dois gêneros, cujo centro de diversidade na região neotropical se encontra no referido domínio (Batista \& Bianchetti 2010; Pansarin 2005), comumente apresentam elevada diversidade nas formações de campo limpo, sobretudo em regiões de altitude, onde se mantêm latentes na forma de tuberoides na estação seca e brotam e florescem durante, e pouco após, a estação chuvosa, entre janeiro e abril, geralmente.

A maioria das espécies $(60 \%)$ ocorre em vegetações campestres (campo limpo e/ou campo rupestre), enquanto as $40 \%$ restantes ocorrem nas formações florestais (capão de mata, mata de galeria e/ou Floresta Estacional Semidecidual). No que concerne aos hábitos, $59 \%$ das espécies são terrícolas, $28 \%$ epífitas e 13\% rupícolas e/ou saxícolas. Essa condição de predomínio de espécies que ocorrem em vegetação campestre e de hábito terrícola está relacionada com o que já foi comentado anteriormente: uma vasta extensão de áreas de campo limpo e a riqueza elevada de gêneros como Habenaria e Cleistes, além da presença, também, de muitas espécies da subtribo Spiranthinae ( 9 spp.), grupos estes formados predominantemente por plantas terrícolas.

Ao comparamos a riqueza florística da $\mathrm{SOB}$ com as demais áreas da Cadeia do Espinhaço e regiões montanhosas do leste de Minas Gerais (de acordo com os trabalhos citados no sexto parágrafo da introdução), verificamos um percentual de $17 \% \mathrm{em}$ relação ao número de espécies ( $75 \mathrm{spp}$. de um total de ca. 435 spp.) e 34\% ao número de gêneros (36 de um total de ca. 105), o que sugere representatividade florística para a área de estudo. Há, ainda, espécies apresentadas neste trabalho que, até então, não constavam nas listagens para o conjunto de regiões em questão, são elas: Brasilaelia virens (Lindl.) Campacci, Campylocentrum spannagelii Hoehne, Habenaria crucifera Rchb.f. \& Warm., Prosthechea 

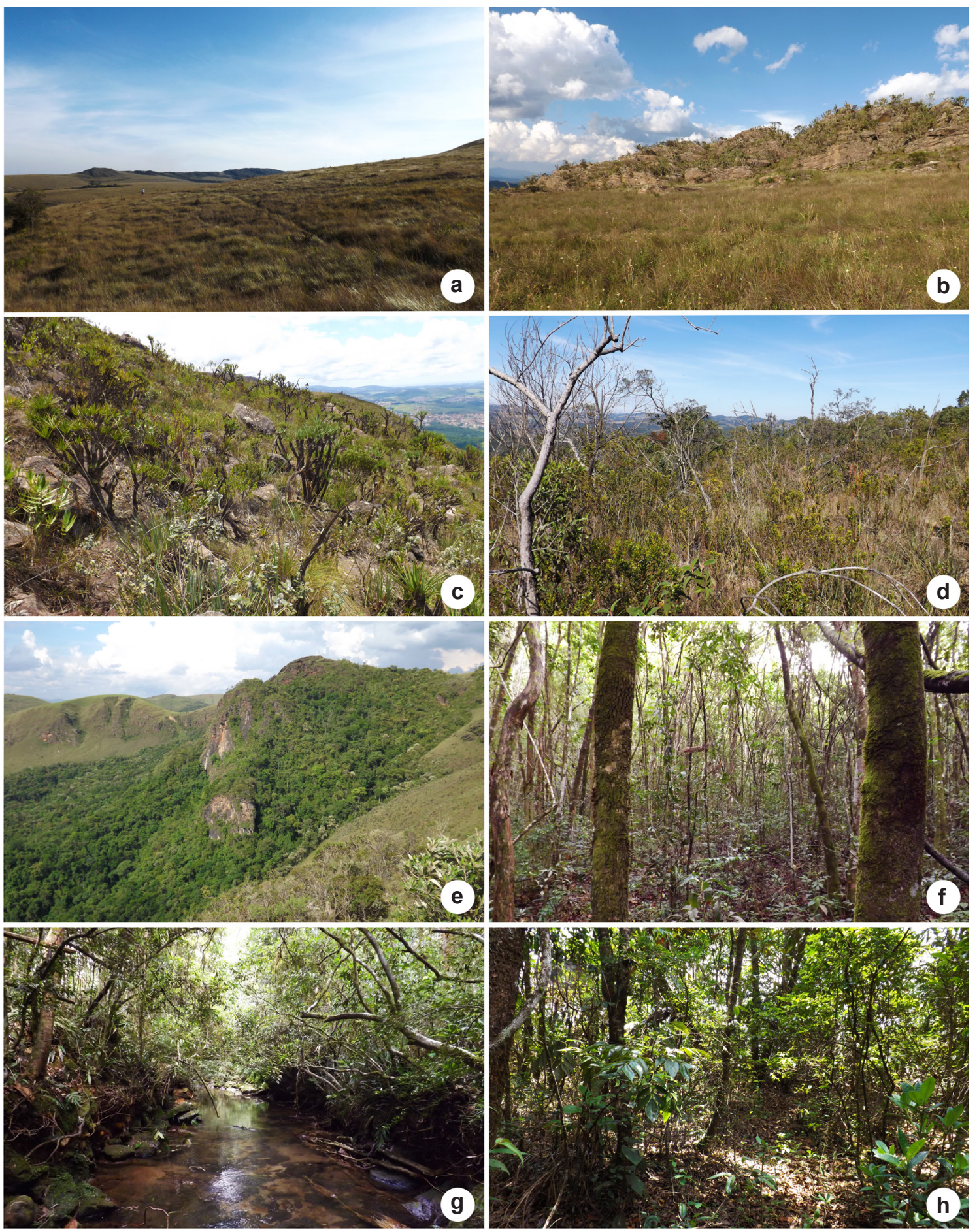

Figura 2 - Principais fitofisionomias encontradas na Serra do Ouro Branco, Minas Gerais. a. visão geral do campo limpo. b. campo limpo em primeiro plano e afloramento no campo rupestre ao fundo. c. campo rupestre. d. Cerrado s.s. e. vista da Floresta Estacional Semidecidual (FES) na vertente norte da serra. f. interior da FES. g. mata de galeria. h. interior de Capão de Mata. Fotos: T.L. Vieira.

Figure 2 - Main phytophisiognomies found in the Serra do Ouro Branco, Minas Gerais. a. geneeral view of the open field. b. open field in the foreground and rocky field in the background. c. rocky field. d. Cerrado s.s. e. view of Semideciduous Seazonal Forest (SSF) in the north mountainside. f. interior view of SSF. g. gallery forest. h. interior view of a Capão de Mata. Photos: T.L. Vieira. 
bulbosa (Vell.) W.E.Higgins e Skeptrostachys balanophorostachya (Rchb.f. \& Warm.) Garay.

Dentre as espécies listadas, apenas Hadrolaelia brevipedunculata (Cogn.) Chiron \& V.P.Castro é considerada como ameaçada de extinção, de acordo com Menini Neto et al. (2013), avaliada na categoria "vulnerável". A SOB é a localidade tipo desta espécie, o que torna a área especialmente importante para a conservação deste táxon.

Apesar da SOB encontrar-se atualmente na condição de uma UC, algumas ameaças à biodiversidade da região puderam ser atestadas durante os trabalhos de campo: o corte de madeira nativa nas matas de galeria e áreas de Floresta Estacional Semidecidual, além da ocorrência relativamente frequente de queimadas ao longo da serra. O parque não é fisicamente delimitado com cercas, por exemplo, e há uma estrada que percorre um grande trecho sobre da serra, sem nenhum tipo de controle ao seu acesso. Uma portaria no acesso à estrada e um maior contingente de guarda-parques já permitiriam uma maior fiscalização sobre a área da UC.

A elevada riqueza de Orchidaceae encontrada na SOB, uma área relativamente pequena quando comparada a outras serras na Cadeia do Espinhaço e leste de Minas Gerais, reflete, além da importância florística da família, também a relevância ambiental dessa área, bem como de outras áreas montanhosas com formações quartzíticas, as quais representam refúgios de biodiversidade, tratando-se, portanto, de áreas prioritárias para a conservação.

\section{Chave de identificação para os gêneros de Orchidaceae ocorrentes na Serra do Ouro Branco, Minas Gerais}

1. Inflorescência lateral.

2. Crescimento monopodial; caule não intumescido em pseudobulbo

7. Campylocentrum

2'. Crescimento simpodial; caule (cauloma) intumescido em pseudobulbo.

3. Flores calcaradas.

4. Sépalas laterais coalescentes em toda sua extensão, formando um sinsépalo; base do ginostêmio não projetada em pé 10. Comparettia

4'. Sépalas laterais livres entre si; base do ginostêmio projetada em pé.

5. Folhas não variegadas; flores alaranjadas; sépalas laterais adnatas ao pé da coluna 3. Bifrenaria

5'. Folhas variegadas; flores creme-esverdeadas, com labelo alvo maculado de vináceo; sépalas laterais livres

25. Oeceoclades

3'. Flores ecalcaradas.

6. Inflorescência em panícula; sépalas laterais coalescentes.

7. Plantas terrícolas ou saxícolas; pétalas $7 \times 4-4,5 \mathrm{~mm}$; labelo $12-14 \times 13 \mathrm{~mm}$, com calosidade verrucosa na base.

11 Coppensia

7'. Plantas epífitas; pétalas 21-30 × 15-24 mm; labelo 24-32 × 24-31 mm, com calosidade verrucosa e digitiforme, na base, e protuberância central adunca

5. Brasilidium

6'. Inflorescência em racemo; sépalas laterais livres entre si.

8. Pseudobulbos tetrágonos em seção transversal; sépala dorsal triangular-lanceolada; ginostêmio portando par de antenas no ápice.. 6. Bulbophyllum

8'. Pseudobulbos não formando ângulos em seção transversal; sépala dorsal elíptica, oblonga ou oblongo-elíptica; ginostêmio não portando par de antenas no ápice.

9. Plantas epífitas, $3,5-4,5 \mathrm{~cm}$ alt.; calo do labelo formado por duas lamelas longitudinais da base até cerca de metade do comprimento do mesmo; ginostêmio sem base projetada em pé.....

8. Capanemia

9'. Plantas terrícolas ou saxícolas, 38-90 cm alt.; calo do labelo disposto transversalmente na base do mesmo; ginostêmio com base projetada em pé. 10. Pseudobulbos 1-2-foliados; labelo trilobado 22. Koellensteinia 10'. Pseudobulbos 3-6-foliados; labelo inteiro 36. Zygopetalum 
1'. Inflorescência terminal.

11. Caule (cauloma) intumescido em pseudobulbo.

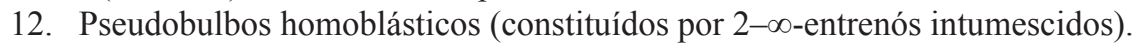

13. Flores não ressupinadas.

14. Plantas terrícolas; folhas membranáceas; inflorescência em corimbo; labelo inteiro, largo-triangular, ápice tridentado

14'. Plantas epífitas; folhas coriáceas; inflorescência em racemo ou panícula; labelo trilobado de âmbito depressamente ovado, ápice emarginado ou arredondado......

13'. Flores ressupinadas.

15. Folhas linear-lanceoladas; flores calcaradas. 27. Polystachya

15'. Folhas elíptico-lanceoladas, elípticas ou obovadas; flores ecalcaradas.

16. Plantas terrícolas; folhas membranáceas; labelo inteiro, livre do ginostêmio em sua extensão. 23. Liparis

16'. Plantas rupícolas ou saxícolas; folhas coriáceas; labelo trilobado a subtrilobado, com unguículo adnato às margens do ginostêmio.

13. Epidendrum (E. campestre)

12'. Pseudobulbos heteroblásticos (constituídos por apenas 1 entrenó intumescido).

17. Labelo inteiro, adnato ao ginostêmio em maior ou menor extensão.

18. Inflorescência multiflora; flores alvas, não ressupinadas; labelo adnato ao ginostêmio até ca. $1 / 2$ da extensão deste.

29. Prosthechea

18'. Inflorescência uniflora; flores lilases, ressupinadas; labelo adnato ao ginsotêmio apenas na base.... 20. Isabelia

17'. Labelo trilobado, livre.

19. Pseudobulbos 2-3-foliados; inflorescência em panícula.

12. Encyclia

19'. Pseudobulbos 1-foliados; inflorescência 1-flora ou em racemo.

20. Pétalas obovadas, 1,2-2,4 cm larg., ápice obtuso; lobo mediano do labelo com margem inteira. 18. Hadrolaelia

20’. Pétalas elíptico-falcadas, 3-8 mm larg., ápice agudo a acuminado; lobo mediano do labelo com margem ondulada.

21. Plantas rupícolas ou saxícolas; flores amarelas ou lilases; polínias $8 \ldots . .$. 19. Hoffmannseggella

21'. Plantas epífitas; flores esverdeadas com labelo alvo-esverdeado; polínias 4 4. Brasilaelia

11'. Caule (cauloma) não intumescido em pseudobulbo.

22. Cauloma 1-foliado; zona de abscisão entre pedicelo e ovário presente (o pedicelo é persistente).

23. Plantas predominantemente epífitas sobre Vellozia; inflorescência 2-flora; sépalas laterais livres entre si

2. Anathallis

23'. Plantas rupícolas, saxícolas, terrícolas ou epífitas sobre outros forófitos que não Vellozia; inflorescência 4- $\infty$-flora; sépalas laterais coalescentes, formando sinsépalo

1. Acianthera

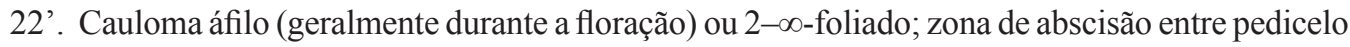
e ovário ausente.

24. Folhas alternas, dísticas.

25. Sépalas livres entre si; labelo com unguículo alongado e adnato às margens do ginostêmio 13. Epidendrum

25'. Sépalas laterais parcialmente adnatas à dorsal e coalescentes em sinsépalo até $2 / 3$ de sua extensão; labelo com unguiculo curto e articulado com o pé do ginostêmio

21. Isochilus

24'. Folhas alternas, espiraladas, rosuladas, ou plantas áfilas durante a floração.

26. Flores não ressupinadas; labelo elmiforme

28. Prescottia

26’. Flores ressupinadas; labelo não elmiforme. 
27. Flores calcaradas; grãos de pólen aglutinados em polínias sécteis

17. Habenaria

27'. Flores ecalcaradas; grãos de pólen livres ou aglutinados em polínias farinosas.

28. Pétalas livres; margens do labelo livres do ginostêmio; antera apical, incumbente; grãos de pólen livres, em mônades ou tétrades, não formando polínias verdadeiras; zona de abscisão entre ovário e perianto presente.

29. Folhas com venação reticulada; calículo presente; glândulas nectaríferas ausentes na base do labelo 14. Epistephium

29'. Folhas com venação paralelinérvea; calículo ausente; par de glândulas nectaríferas presente na base do labelo. 9. Cleistes

28'. Pétalas aderidas à sépala dorsal; margens do labelo aderidas ao ginostêmio; antera dorsal, ereta; grãos de pólen aglutinados em polínias verdadeiras, farinosas; zona de abscisão entre ovário e perianto ausente.

30. Plantas epífitas.

15. Eurystyles

30'. Plantas terrícolas.

31. Folhas presentes durante a floração.

32. Folhas espiraladas ao longo do caule; flores sésseis; rostelo rígido. .. 33. Skeptrostachys

32'. Folhas rosuladas na base da planta; flores pediceladas; rostelo maleável.

33. Inflorescência ca. $1 \mathrm{~m}$ compr. 32. Sauroglossum

33'. Inflorescência até ca. $5 \mathrm{~mm}$ compr.

34. Folhas pecioladas; lâmina foliar ligeiramente assimétrica; sépalas com comprimento semelhante entre si. 34. Stigmatosema

34'. Folhas sésseis; lâmina foliar simétrica; sépalas laterais com pouco menos que o dobro do comprimento da sépala dorsal

31'. Folhas ausentes ou em estado de senescência durante a floração.

35. Flores róseo-avermelhadas; rostelo rígido, acicular. 31. Sarcoglottis

5'. Flores alvo-esverdeadas ou alvo-acastanhadas; rostelo membranáceo ou maleável, laminar.

36. Flores alvo-acastanhadas; par de glândulas nectaríferas pubescentes presentes, na base do labelo; ápice das pétalas agudo 31. Sarcoglottis

36'. Flores alvo-esverdeadas; par de glândulas nectaríferas pubescentes ausentes, na base do labelo; ápice das pétalas obtuso ou arredondado.

37. Sépalas laterais coalescentes na base, formando mento saquiforme........

37'. Sépalas laterais coalescentes até ca. 1/2 do seu comprimento, formando mento alongado 35. Veyretia

\section{Acianthera Scheidw.}

Ervas epífitas, saxícolas, rupícolas ou humícolas. Crescimento simpodial. Raízes filiformes, cobertas por velame. Rizoma inconspícuo a longo. Cauloma não intumescido em pseudobulbo, homoblástico, cilíndrico a tríquetro, 1-foliado. Folha no ápice do cauloma, variando entre verde, amarelado e vináceo, comumente carnosa, séssil. Inflorescência terminal, geralmente em racemo, $1-\infty$-flora. Flores pediceladas, pedicelo persistente na inflorescência, zona de abscisão entre pedicelo e ovário, ressupinadas, ecalcaradas, creme-esverdeadas, amarelas ou em variados tons de vináceo a castanho-avermelhado, membranáceas a carnosas; sépalas de tamanho e forma semelhante, a dorsal livre, as laterais adnatas, na base, ao pé da coluna e coalescentes entre si, em maior ou menor extensão, geralmente formando sinsépalo, comumente carenadas; pétalas livres, mais curtas e estreitas que as sépalas; labelo inteiro ou trilobado, calosidade, quando presfogente, constituída por um calo transversal na base do labelo ou por duas lamelas longitudinais na porção mediana do labelo, lobos laterais, quando presentes, normalmente reduzidos, lobo mediano de forma variável, base geralmente unguiculada, articulada com o pé da coluna. Ginostêmio cilíndrico a claviforme, muitas vezes encurvado, base projetada em pé; antera apical, incumbente, versátil; grãos de pólen aglutinados em polínias. Polínias 2, maciças, nuas ou dotadas de caudículas reduzidas. Zona de abscisão entre ovário e pedicelo presente. 


\section{Chave de identificação para espécies de Acianthera ocorrentes na Serra do Ouro Branco}

1. Folhas planas.

2. Cauloma cilíndrico em toda sua extensão; flores externamente pubescentes 4. Acianthera saurocephala

2'. Cauloma cilíndrico apenas na base, tornando-se lateralmente compresso ou tríqueto em direção ao ápice; flores externamente glabras.

3. Cauloma tornando-selateralmente compresso em direção ao ápice; flores predomimantemente lilases; labelo sem calo na base. 2. Acianthera limae

3'. Cauloma tornando-se tríquetro em direção ao ápice; flores predominantemente cremeesverdeadas ou amarelas; labelo com calo transversal na base.

4. Raque 1,5-8 cm compr.; flores creme-esverdeadas com listras longitudinais vináceas; sépalas laterais coalescentes em toda sua extensão; labelo inteiro, ca. 4,5 mm compr...

3. Acianthera malachantha

4'. Raque 0,8-1,3 cm compr.; flores amarelas; sépalas laterais coalescentes em $2 / 3$ de sua extensão; labelo trilobado, 2,7-3 cm compr.. 1. Acianthera auriculata

1'. Folhas fortemente conduplicadas ou subcilíndricas.

5. Plantas rupícolas, normalmente crescendo sobre rocha nua, em afloramentos; folhas subcilíndricas; inflorescência ultrapassando o comprimento da folha 6. Acianthera teres

5'. Plantas saxícolas ou humícolas; folhas conduplicadas; inflorescência não ultrapassando o comprimento da folha.

6. Plantas crescendo em áreas sombreadas, como humícola, no interior de matas; cauloma 4,7-14,5 cm compr.; folha 5,3-8,6 cm compr.

2. Acianthera limae

6'. Plantas crescendo a sol pleno em afloramentos, como saxícola, nos campos rupestres; cauloma geralmente inconspícuo, podendo alcançar até 3,5 cm compr.; folha $0,8-3,5 \mathrm{~cm}$ compr........

1.1. Acianthera auriculata (Lindl.) Pridgeon \& M.W.Chase, Lindleyana 16(4): 242. 2001.

Fig. 3a

Epífita, 7-10 cm alt. Cauloma cilíndrico na base, tornando-se tríquetro em direção ao ápice, coberto por bainhas escariosas, maculadas de vináceo, 3,5-5,2 cm compr. Folha ereta a subereta, plana, coriácea, verde, estreito-elíptica a lanceolada, $3,1-4,8 \times(0,4-) 0,6-0,8 \mathrm{~cm}$, séssil, ápice obtuso. Inflorescência sublaxa, 4-7-flora; pedúnculo ca. 1,5 cm compr.; espata ovada, amplectiva, escariosa, ca. 3-5 × 1,5-2,5 mm, ápice agudo; brácteas do pedúnculo tubulosas 2-2,5 $\times$ $1-1,5 \mathrm{~mm}$, ápice truncado ou assimétrico; raque 8-13 mm compr.; brácteas florais tubulosas, ca. $1,5 \times 1,5 \mathrm{~mm}$, ápice assimétrico. Flores amarelas, glabras; sépala dorsal elíptico-lanceolada, 4,5-5× $2 \mathrm{~mm}$, ápice obtuso; sépalas laterais coalescentes em sinsépalo até cerca de $2 / 3$ de sua extensão, carenadas, lanceoladas, 4,5-5 × 1-1,5 mm, ápice agudo; pétalas elípticas, ca. $3 \times 1,5 \mathrm{~mm}$, ápice agudo; labelo trilobado, âmbito ovado, 2,7-3 $\times$ 1,5-2 mm, calo na base do labelo, transversal, semiorbicular; lobos laterais falcados, $0,7-1,2 \times 0,3-0,7$ $\mathrm{mm}$, ápice agudo, margem inteira; lobo mediano hemi-elíptico, ca. 1,5×1 mm, ápice agudo, margem inteira. Ginostêmio 2-2,5 mm compr., pé ca. 0,75 $\mathrm{mm}$ compr. Ovário + pedicelo ca. $2 \mathrm{~mm}$ compr. Fruto não visto.

Material examinado: Capão de mata ca. $400 \mathrm{~m}$ a oeste das antenas, 25.VI.2014, fl. cult. IX.2014, T.L. Vieira 205 (SP).

Acianthera auriculata tem ocorrência conhecida para a Bolívia e o Brasil, nos estados da Bahia e das regiões Sudeste e Sul (BFG 2015; Govaerts 2015). Na SOB foi coletada em capão de mata, em torno dos $1.400 \mathrm{~m}$ de altitude. Floresceu em cultivo em setembro. Entre as demais espécies do gênero para a $\mathrm{SOB}, A$. auriculata é próxima de $A$. malachantha, que também pertence ao subgênero Arthrosia, mas a primeira apresenta folhas geralmente mais estreitas, inflorescência mais curta e flores amarelas ( $v s$. creme-esverdeadas com listras vináceas).

Luer (1986) subordinou esta espécie, primeiramente, ao subgênero Arthrosia de Pleurothallis R.Br. s.l., no qual agrupou as espécies do gênero distribuídas principalmente entre a Bolívia e o Sudeste do Brasil que apresentam um calo transversal, na base do labelo, com o qual se articula o pé da coluna. Posteriormente, Pridgeon $\&$ Chase (2001) verificaram, a partir de dados moleculares, o polifiletismo de Pleurothallis s.l., 


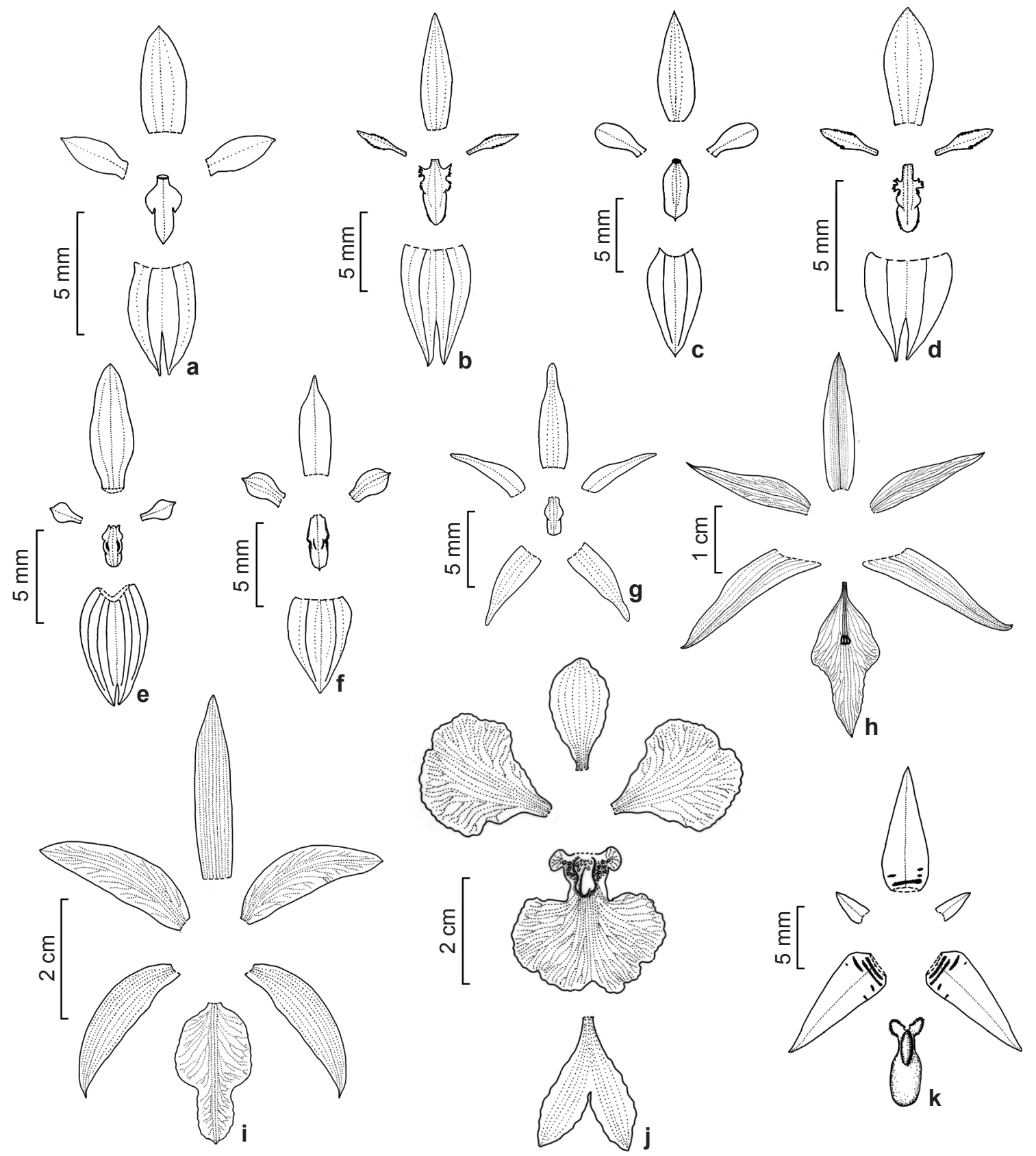

Figura 3 - Periantos dissecados. a. Acianthera auriculata (T.L. Vieira 205). b. Acianthera limae (T.L. Vieira 143). c. Acianthera malachantha (T.L. Vieira 254). d. Acianthera modestissima (T.L. Vieira 264). e. Acianthera saurocephala (T.L. Vieira 204). f. Acianthera teres (T.L. Vieira 159). g. Anathallis aristulata (T.L. Vieira 184). h. Bifrenaria aureofulva (T.L. Vieira 225). i. Brasilaelia virens (J. Badini $s / n$ ). j. Brasilidium gravesianum (T.L. Vieira 260). k. Bulbophyllum exaltatum (T.L. Vieira 177).

Figure 3 - a. Acianthera auriculata (T.L. Vieira 205). b. Acianthera limae (T.L. Vieira 143). c. Acianthera malachantha (T.L. Vieira 254). d. Acianthera modestissima (T.L. Vieira 264). e. Acianthera saurocephala (T.L. Vieira 204). f. Acianthera teres (T.L. Vieira 159). g. Anathallis aristulata (T.L. Vieira 184). h. Bifrenaria aureofulva (T.L. Vieira 225). i. Brasilaelia virens (J. Badini s/n). j. Brasilidium gravesianum (T.L. Vieira 260). k. Bulbophyllum exaltatum (T.L. Vieira 177). 
situação que acarretou a divisão do gênero em grupos menores, com muitas das espécies brasileiras incluídas no gênero Acianthera, condição esta que vem sendo bem aceita, atualmente. No entanto, vale comentar, ainda, que Luer (2006) elevou o status do subgênero Arthrosia para gênero (Artrhosia Luer), uma vez que não aceitou plenamente as circunscrições genéricas propostas por Pridgeon \& Chase (2001). Apesar disso, a inclusão de Artrhosia dentro de Acianthera ainda é o conceito mais bem aceito. Vale comentar, ainda, que Chiron \& Van den Berg (2012), em uma proposta de revisão do gênero Acianthera, criaram a seção Arthrosiae, na qual incluem as espécies deste grupo.

1.2. Acianthera limae (Porto \& Brade) Pridgeon \& M.W.Chase, Lindleyana 16(4): 244. 2001.

Fig. $3 b$

Humícola, 6-22 cm alt. Cauloma cilíndrico na base, tornando-se fortemente lateralmente compresso em direção ao ápice, coberto por bainhas escariosas, 4,7-14,5 cm compr. Folha subpatente, patente ou reflexa, plana a conduplicada, coriácea a carnosa, variando entre verde e vináceo, elíptico-lanceolada a lanceolada, 5,3-8,6 × $1,2-2,1 \mathrm{~cm}$, séssil, ápice agudo. Inflorescência subcongesta, 4-5-flora; pedúnculo 3-6 $\mathrm{mm}$ compr.; espata ovada, amplectiva, escariosa, 4-5 × 3,5-4 mm, ápice agudo; bráctea do pedúnculo, quando presente, tubulosa ca. 2,5 $\times 2$ $\mathrm{mm}$, ápice assimétrico; raque $8-12 \mathrm{~mm}$ compr.; brácteas florais tubulosas 1,5-2 × 2-3 mm, ápice assimétrico. Flores predominantemente lilases, com listras longitudinais vináceas, glabras; sépala dorsal lanceolada a oblongo-lanceolada, 6-8 $\times 2$ $\mathrm{mm}$, ápice agudo; sépalas laterais coalescentes em sinsépalo até cerca de $2 / 3$ de sua extensão, carenadas, lanceoladas, 6,5-8 × 2-3 mm, ápice agudo; pétalas estreito-rômbicas, 3-3,5 $\times 1 \mathrm{~mm}$, ápice agudo; labelo inconspicuamente trilobado, âmbito elíptico, 4-5 × 1,5-2 mm, calo na base do labelo ausente; lobos laterais orbiculares, diminutos, ápice arredondado, margem recortada; lobo mediano hemi-elíptico, 1,5-2 × 1,5-2 mm, ápice arredondado, margem recortada próximo ao ápice. Ginostêmio ca. $2 \mathrm{~mm}$ compr., base projetada formando pé, $0,5-0,8 \mathrm{~mm}$ compr. Ovário + pedicelo $2-3,5 \mathrm{~mm}$ compr. Fruto não visto.

Material examinado: próximo ao Morro do Gabriel, imediações de uma antiga ponte da Estrada Real, 14.IX.2013, fl., T.L. Vieira et al. 143 (SP); 14.IX.2013, f1. cult. XII.2013, T.L. Vieira et al. 262 (SP); 14.IX.2013, fl. cult. IV.2014, T.L. Vieira et al. 263 (SP).
Acianthera limae é endêmica do Brasil, com distribuição conhecida para os estados do Espírito Santo, Minas Gerais e Rio de Janeiro (BFG 2015). Na SOB foi encontrada como humícola em barrancos na Floresta Estacional Semidecidual, no norte da serra. Floresce durante todo o ano. A espécie pertence ao complexo Acianthera prolifera (Melo \& Borba 2011; Melo et al. 2011), juntamente com A. hamosa (Barb.Rodr.) Pridgeon \& M.W.Chase, A. modestissima (Rchb.f. \& Warm.) Pridgeon \& M.W.Chase e A. prolifera (Herb. ex Lindl.) Pridgeon \& M.W.Chase. São espécies que ocorrem principalmente nas regiões montanhosas da Região Sudeste brasileira, muitas vezes em simpatria, possuindo uma convergência no que diz respeito à sua morfologia floral, além de uma notável plasticidade fenotípica das estruturas vegetativas, o que acarreta dificuldades na delimitação entre as espécies.

Na SOB, além da A. limae, ocorre também A. modestissima. Estas podem ser facilmente diferenciadas pelo tamanho das plantas, com a primeira apresentando cauloma de 4,7-14,5 cm compr. (vs. cauloma que vai de inconspícuo até ca. 3,5 cm compr.), folha de 5,3-8,6 $\times 1,2-2,1 \mathrm{~cm}$ (vs. $0,8-3,5 \times 0,6-1,8 \mathrm{~cm}$ ), além do habitat, pois A. limae ocorre em matas e A. modestissima em campo rupestre.

1.3. Acianthera malachantha (Rchb.f.) Pridgeon \& M.W.Chase, Lindleyana 16(4): 244. 2001.

Fig. 3c

Epífita, 6,5-24 $\mathrm{cm}$ alt. Cauloma cilíndrico na base, tornando-se tríquetro em direção ao ápice, coberto por bainhas escariosas maculadas de vináceo, 1,5-15 $\mathrm{cm}$ compr. Folha ereta a subpatente, plana, carnosa, verde, esparsamente maculada de vináceo, oblongo-elíptica a elípticolanceolada, 3,8-7,2 × 0,8-1,7 cm, séssil, ápice obtuso. Inflorescência laxa, pauci a multiflora; pedúnculo 2,3-4,1 cm compr.; espata ovada, amplectiva, escariosa, 4-11 × 2-3,5 $\mathrm{mm}$, ápice agudo; brácteas do pedúnculo, quando presentes, tubulosas 3-6 × 1,5-2 mm, ápice assimétrico; raque $1,5-8 \mathrm{~cm}$ compr.; brácteas florais tubulosas $2-3,5 \times 2-3 \mathrm{~mm}$, ápice assimétrico. Flores cremeesverdeadas, com listras longitudinais vináceas, glabras; sépala dorsal elíptico-lanceolada, 7-7,5 $\times 2-2,5 \mathrm{~mm}$, ápice agudo; sépalas laterais coalescentes em sinsépalo ovado por toda sua extensão, carenadas, sinsépalo 7-7,5 × $4 \mathrm{~mm}$, ápice agudo; pétalas obovadas, ligeiramente falcadas, $3,5-4 \times 1,5 \mathrm{~mm}$, ápice apiculado a arredondado; 
labelo inteiro, oblongo-elíptico, ca. 4,5 × $2 \mathrm{~mm}$, ápice apiculado, margem inteira; calo na base do labelo transversal, semi-orbicular. Ginostêmio 3-3,5 mm compr., pé ca. $1 \mathrm{~mm}$ compr. Ovário + pedicelo ca. $3 \mathrm{~mm}$ compr. Fruto não visto.

Material examinado: Sine loco, 26.VI.2014, fl., T.L. Vieira 212 (SP); 26.VI.2014, fl. cult. XII.2014, T.L. Vieira 261 (SP); 30.I.2015, fl., T.L. Vieira 254 (SP, $\mathrm{BHCB}, \mathrm{RB})$.

Acianthera malachantha é endêmica do Brasil, com distribuição conhecida para os estados da Bahia, Minas Gerais, Rio de Janeiro e Santa Catarina (BFG 2015). Na SOB foi encontrada como epífita, em fuste, em matas de galeria e capões de mata. Foi encontrada florida em junho e também de dezembro a janeiro. Ver comentários em A. auriculata.

1.4. Acianthera modestissima (Rchb.f. \& Warm.) Pridgeon \& M.W.Chase, Lindleyana 16(4): 244245. 2001.

Fig. 3d

Saxícola, 1,5-4,5 cm alt. Cauloma inconspícuo ou, quando conspícuo, cilíndrico na base tornandose lateralmente compresso em direção ao ápice e coberto por bainhas escariosas, atingindo até 3,5 cm compr. Folha patente a reflexa, conduplicada, carnosa, variando entre verde e vináceo, ovada a elíptica, 0,8-3,5 × 0,6-1,8 cm, séssil, ápice agudo a apiculado. Inflorescência congesta, 4-5-flora; pedúnculo ca. 1,5 mm compr.; espata ovada, amplectiva, escariosa, ca. 2,2 × 1,5 mm, ápice obtuso; raque ca. $6,5 \mathrm{~mm}$ compr.; brácteas florais tubulosas 1-1,5 × 1-1,5 mm, ápice assimétrico. Flores vináceas, glabras; sépala dorsal oblongoelíptica, 3,5-4,5 × 1,5 mm, ápice obtuso a agudo; sépalas laterais coalescentes em sinsépalo até cerca de $2 / 3$ de sua extensão, carenadas, ovadas a lanceoladas, 3-4 × 1,5 mm, ápice agudo; pétalas estreito-rômbicas, 2-2,3 × $1 \mathrm{~mm}$, ápice agudo; labelo inconspicuamente trilobado, âmbito oblanceolado, 2,6-2,8 × 1,2 mm; lobos laterais orbiculares, diminutos, ápice arredondado, margem recortada; lobo mediano hemi-elíptico, 0,75-1 × 0,75-1 mm, ápice arredondado, margem recortada próximo ao ápice. Ginostêmio 1,5-2 mm compr., base projetada formando pé, 0,75-1 mm compr. Ovário + pedicelo ca. 2,3 mm compr. Fruto não visto.

Material examinado: afloramentos próximos às antenas, voltados para o Sul, 18.III.2014, fl., T.L. Vieira 192 (SP); 18.III.2014, fl. cult. XII.2014, T.L. Vieira 264 (SP).

Acianthera modestissima é endêmica do Brasil, com distribuição conhecida para os estados da Bahia, Minas Gerais, Paraná, Rio de Janeiro e
São Paulo (BFG 2015). Na SOB foi encontrada como saxícola, em afloramento quartzítico no campo rupestre. Floresce durante praticamente todo o ano. Ver comentários em $A$. limae.

1.5. Acianthera saurocephala (Lodd.) Pridgeon \& M.W.Chase, Lindleyana 16(4): 246. 2001.

Fig. 3e

Epífita, 12,5-18,5 cm alt. Cauloma cilíndrico em toda sua extensão, coberto por bainhas escariosas, 3,5-9,5 cm compr. Folha ereta a subereta, plana, carnosa, verde, elíptica, 5,5-8,5 $\times 1,7-2,8 \mathrm{~cm}$, séssil, ápice obtuso. Inflorescência sublaxa, multiflora; pedúnculo 2,4-3,8 cm compr.; espata elíptica, amplectiva, escariosa, 2,1-2,6 × 0,8-1 cm, ápice obtuso; brácteas do pedúnculo tubulosas, ca. $4 \times 4 \mathrm{~mm}$, ápice assimétrico; raque $3,1-7 \mathrm{~cm}$ compr.; brácteas florais tubulosas 2-4×3-4 mm, ápice assimétrico. Flores atropurpúreas, externamente pubescentes; sépala dorsal lanceolada, 6-7 × 2-2,5 mm, ápice agudo; sépalas laterais coalescentes em sinsépalo até $2 / 3$ do seu comprimento, lanceoladas, 6-6,5 $\times$ 1,5-2 mm, ápice agudo; pétalas obovadas, ca. $2 \times$ $1 \mathrm{~mm}$, ápice apiculado; labelo inconspicuamente trilobado, âmbito ovado, ca. 2,5 × 1,5 mm; dois calos longitudinais próximos às margens na porção mediana do labelo; lobos laterais orbiculares, diminutos, ápice arredondado, margem inteira; lobo mediano hemi-elíptico, ca. $1 \times 1 \mathrm{~mm}$, ápice arredondado, margem inteira. Ginostêmio 1,5-2 mm compr., pé ca. 0,75 mm compr. Ovário + pedicelo ca. $5 \mathrm{~mm}$ compr. Fruto não visto.

Material examinado: Sine loco, 6.X.2009, fl. cult. no Museu de História Natural e Jardim Botânico da UFMG, E.C. Smidt et al. 850 (BHCB); capão de mata, ca. $1 \mathrm{~km}$ a oeste das antenas, 24.VI.2014, fl. cult. 7.X.2014, T.L. Vieira 204 (SP, BHCB).

Acianthera saurocephala é endêmica do Brasil, com distribuição conhecida para os estados da Bahia e das regiões Sudeste e Sul (BFG 2015). $\mathrm{Na}$ SOB foi encontrada como epífita, em fuste, em capão de mata. Floresce em outubro. Pode ser facilmente diferenciada das demais espécies do gênero para a SOB por suas folhas elípticas fortemente carnosas, associadas à inflorescência que, geralmente, ultrapassa o comprimento da folha, portando flores carnosas, de coloração atropurpúrea, externamente pubescentes.

1.6. Acianthera teres (Lindl.) Borba, Sitientibus Ser. Ci. Biol. 3(1/2): 23. $2003 . \quad$ Fig. $3 f$

Rupícola, 4,5-9,5 cm alt. Cauloma inconspícuo, formando um contínuo com a folha, 
coberto por bainha escariosa. Folha ereta a curvada, muito carnosa, esverdeada a vinácea, subcilíndrica, $1,8-8 \times 0,5-1 \mathrm{~cm}$, séssil, ápice agudo. Inflorescência sublaxa, 7-10-flora; pedúnculo 1,8-5 cm compr.; espata ovada, amplectiva, ca. $5 \times 3 \mathrm{~mm}$, ápice agudo; brácteas do pedúnculo, quando presentes, tubulosas, 4-5 $\times 4 \mathrm{~mm}$, ápice assimétrico; raque 0,8-4 cm compr.; brácteas florais tubulosas 3-5 $\times 3 \mathrm{~mm}$, ápice assimétrico. Flores vináceoalaranjadas, glabras; sépala dorsal oblongo-elíptica, carenada, ca. $6 \times 2 \mathrm{~mm}$, ápice agudo; sépalas laterais coalescentes em sinsépalo navicular por toda sua extensão, carenadas, sinsépalo $6 \times 3-4$ $\mathrm{mm}$, ápice agudo; pétalas obovadas, ligeiramente falcadas, 2,5 × 1-1,5 mm, ápice apiculado; labelo inconspicuamente trilobado, oblongo, ca. $3 \times 1$ $\mathrm{mm}$; dois calos longitudinais próximos às margens na porção mediana do labelo; lobos laterais orbiculares, diminutos, ápice arredondado, margem inteira; lobo mediano hemi-elíptico, ca. 1,8 $\times 1$ $\mathrm{mm}$, ápice arredondado a acuminado, margem inteira. Ginostêmio ca $2 \mathrm{~mm}$ compr., pé ca. 0,75 $\mathrm{mm}$ compr. Ovário + pedicelo ca. $5 \mathrm{~mm}$ compr. Fruto fusiforme, 6-9 $\times 3 \mathrm{~mm}$.

Material examinado: área 2, 22.I.2002, fl. e fr., C.C. de Paula et al. 618 (VIC); Sine loco, 14.IX.2013, fl. cult. XII.2014, T.L. Vieira et al. 159 (SP); porção leste da serra, lado direito da rodovia MG-443 (sentido Itatiaia), 26.I.2015, fl., T.L. Vieira 217 (SP).

Acianthera teres é endêmica do Brasil, ocorrendo em afloramentos de regiões montanhosas dos estados da Bahia, Espírito Santo, Minas Gerais e Rio de Janeiro (BFG 2015). Na SOB é comumente encontrada como rupícola em afloramentos nos campos rupestres, muitas vezes formando densas populações. Floresce entre dezembro e janeiro. Pode ser facilmente diferenciada das demais espécies do gênero ocorrentes na SOB pela morfologia das folhas, fortemente carnosas e subcilíndricas, além do fato de crescer, predominantemente, sobre rochas nuas em afloramentos nos campos rupestres.

\section{Anathallis Barb.Rodr.}

2.1. Anathallis aristulata (Lindl.) Luer, Monogr. Syst. Bot. Missouri Bot. Gard. 112: 118. 2007.

Fig. $3 \mathrm{~g}$

Epífita, $1-2,5 \mathrm{~cm}$ alt. Crescimento simpodial. Raízes filiformes, cobertas por velame. Rizoma inconspícuo. Cauloma não intumescido em pseudobulbo. Cauloma muito curto, cilíndrico, coberto por bainha escariosa, 1-3,5 mm compr. Folha subereta, conduplicada, carnosa, amarelada a verde, orbicular, elíptica ou obovada, 2,5-7 × 3-3,5 $\mathrm{mm}$, séssil, ápice obtuso. Inflorescência terminal, em racemo, laxa, 2-flora; pedúnculo 3,8-6,5 mm compr.; espata ovada, amplectiva, escariosa, ca. $1,5 \times 1 \mathrm{~mm}$, ápice obtuso; brácteas do pedúnculo tubulosas ca. $1 \times 0,6 \mathrm{~mm}$, ápice truncado, assimétrico; raque 2,2-3 mm compr.; brácteas florais tubulosas ca. $1 \times 0,5 \mathrm{~mm}$, ápice assimétrico. Flores amarelo-pálidas, glabras, ressupinadas, pediceladas; sépala dorsal lanceolada, 3,9-4,7 × 1-1,2 mm, ápice agudo; sépalas laterais adnatas, na base, ao pé da coluna, livres entre si, lanceoladas, levemente falcadas, 3,5-4,6 × 1-1,5 mm, ápice agudo; pétalas lanceoladas, levemente falcadas, $2,7-3,8 \times 0,6-0,8 \mathrm{~mm}$, ápice agudo; labelo unguiculado, articulado com o pé da coluna, inconspicuamente trilobado, âmbito oblongo, $1,4-1,6 \times 0,8-0,9 \mathrm{~mm}$; lobos laterais orbiculares, diminutos, ápice arredondado, margem inteira; lobo mediano hemi-elíptico, ca. 0,6 × 0,6 mm ápice arredondado, margem inteira. Ginostêmio 1,1-1,3 mm compr., base projetada em pé, ca. 0,3 $\mathrm{mm}$ compr; antera apical, incumbente, versátil; grãos de pólen aglutinados em polínias. Polínias 2 , maciças dotadas apenas de caudículas. Ovário + pedicelo 1,5-2,7 mm compr. Zona de abscisão entre pedicelo e ovário presente. Fruto curto-fusiforme, ca. $3,3 \times 2,2 \mathrm{~mm}$.

Material examinado: Sine loco, X.2004, fl., M.A. Campacci 1679 (SP - Holótipo de Anathallis ourobranquensis Capacci \& Menini); 13.IX.2013, fl., T.L. Vieira et al. 137 (SP, BHCB); 17.III.2014, fl. e fr., T.L. Vieira 184 (SP).

Anathallis aristulata é endêmica do Brasil, com distribuição conhecida para o leste do Brasil, desde o Rio Grande do Sul até a região central da Bahia, na Chapada Diamantina (Toscano de Brito \& Luer 2015). Na SOB foi encontrada nas áreas mais altas dos campos rupestres, sempre como epífita sobre Vellozia sp. Floresce entre setembro e outubro, mas também se verificou, em cultivo, floração em março. Trata-se de uma espécie muito distinta, pelo tamanho muito reduzido (1-2,5 $\mathrm{cm}$ alt.), associado ao tipo de forófito, e também por sua inflorescência, geralmente 2-flora, com diminutas flores amarelo-pálidas.

Campacci \& Menini Neto (2005), originalmente, haviam publicado, a partir de material proveniente da SOB, a espécie Anathallis ourobranquensis Campacci \& Menini, aparentemente como endêmica da região. No entanto, foi verificado, a partir do contato com espécimes no campo, análise das coleções dos 
herbários visitados, bem como materiais typi e protólogos, que tratava-se de uma espécie também ocorrente na Chapada Diamantina (Toscano de Brito \& Cribb 2005), Bahia, e que vinha sendo tratada como Anathallis montipelladensis (Hoehne) F.Barros. Todavia, recentemente, Toscano de Brito \& Luer (2015) sinonimizaram ambas sob A. aristulata, agora considerada amplamente distribuída pelo leste brasileiro, ocorrendo desde os 200 aos $1.600 \mathrm{~m}$ de altitude, sendo encontrada na Floresta Atlântica, Cerrado e Caatinga.

\section{Bifrenaria Lindl.}

3.1. Bifrenaria aureofulva (Hook.) Lindl., Edwards's Bot. Reg. 29: t. 52. $1843 . \quad$ Fig. 3h

Saxícola, 17-25 cm alt. Crescimento simpodial. Raízes filiformes, cobertas por velame. Rizoma curto, ca. $1 \mathrm{~cm}$ compr., coberto por bainhas escariosas. Cauloma intumescido em pseudobulbo. Pseudobulbo heteroblástico, ovoide, tetrágono, 2-4 cm compr., 1-foliado. Folha no ápice do pseudobulbo, ereta a subereta, cartácea, verde, elíptica a elíptico-oblanceolada, 10-21,5 × 2,4-3,7 $\mathrm{cm}$, séssil, ápice agudo. Inflorescência lateral, em racemo, laxa, 4-7-flora; pedúnculo 12-15,5 cm compr.; brácteas do pedúnculo amplectivas, adpressas, ovadas, 7-9 × 2-3 mm, ápice agudo; raque $2,3-4,3 \mathrm{~cm}$ compr.; brácteas florais triangulares, 3-5 × 1-2 mm, ápice agudo. Flores alaranjadas, ressupinadas, pediceladas, calcaradas; sépala dorsal elíptico-lanceolada, 1,9-2,1 × 0,4-0,5 $\mathrm{cm}$, ápice agudo; sépalas laterais adnatas, na base, ao pé da coluna, formando o calcar, lanceoladas, levemente falcadas, 1,9-2,2 × 0,4-0,5 cm, ápice agudo; pétalas elíptico-lanceoladas, falcadas, ca. $2 \times 0,4 \mathrm{~cm}$, ápice agudo; labelo unguiculado, articulado com o pé da coluna, inteiro, rômbico a obtrulado, 2,1-2,3 × $1 \mathrm{~cm}$, ápice agudo, margem ondulada próximo ao ápice. Ginostêmio 6-7 mm compr., base projetada em pé, ca. $5 \mathrm{~mm}$ compr.; grãos de pólen aglutinados em polínias. Polínias 4, maciças, providas de viscídio e estipe, este último em formato de "u". Ovário + pedicelo 2-2,4 cm compr. Fruto não visto.

Material examinado: Estrada velha entre Ouro Branco e Ouro Preto, ca de 7 km de Ouro Branco, 9.III.1995, fl., V.C. Souza et al. 8011 (ESA); porção da serra a oeste das antenas, 28.I.2015, fl., T.L. Vieira 225 (SP).

Bifrenaria aureofulva é endêmica do Brasil, com distribuição conhecida para os estados da Região Sudeste, Bahia, Paraná e Santa Catarina (BFG 2015). Na SOB foi encontrada como saxícola no campo rupestre. Floresce entre janeiro e março.
A espécie é de fácil reconhecimento, por apresentar pseudobulbos unifoliados, inflorescência lateral, flores alaranjadas, com aspecto tubular, e as sépalas laterais adnatas ao pé da coluna formando um calcar.

\section{Brasilaelia Campacci}

4.1. Brasilaelia virens (Lindl.) Campacci, Colet. Orquídeas Brasil. 4(Pré-anexo): 100. 2006.

Fig. 3i

Epífita, ca. $29 \mathrm{~cm}$ alt. Crescimento simpodial. Raízes não vistas. Rizoma não visto. Cauloma intumescido em pseudobulbo. Pseudobulbo heteroblástico, fusiforme, sutilmente compresso, ca. $8 \mathrm{~cm}$ compr., 1-foliado. Folha no ápice do pseudobulbo, subereta, plana, coriácea, verde, oblongo-ovada, ca. $19 \times 3,8 \mathrm{~cm}$, séssil, ápice obtuso. Inflorescência em racemo, laxa, 2-flora; pedúnculo ca. $4 \mathrm{~cm}$ compr., espata ca. $6 \mathrm{~cm}$ compr.; raque ca. $1 \mathrm{~cm}$ compr.; brácteas florais deltoides, ca. $3 \times 3 \mathrm{~mm}$, ápice acuminado. Flores ressupinadas, pediceladas; sépala dorsal esverdeada, oblonga, ca. 3,2 $\times 0,6 \mathrm{~cm}$, ápice agudo; sépalas laterais esverdeadas, oblongo-falcadas, ca. 2,5 × 0,6 $\mathrm{cm}$, ápice agudo; pétalas esverdeadas, elípticofalcadas, ca. $3 \times 0,8 \mathrm{~cm}$, ápice agudo; labelo alvoesverdeado, trilobado, livre, âmbito ovado, ca. 2,4 $\times 1,3 \mathrm{~cm}$; calosidade constituída por 3 lamelas longitudinais que se estendem desde a base até o ápice do labelo; lobos laterais oblongos, ca. 1,4 $\times 0,5 \mathrm{~cm}$, margem levemente ondulada, ápice arredondado; lobo mediano oblongo, ca. $1 \times 0,7 \mathrm{~cm}$, ápice obtuso, margem ondulada. Ginostêmio ca. 8 mm compr.; antera apical, incumbente, versátil; grãos de pólen aglutinados em polínias. Polínias 4, maciças, providas apenas de caudículas. Ovário + pedicelo ca. 3,5 cm compr. Fruto não visto.

Material examinado: Sine loco, V.1941, fl., J. Badini (SP).

Brasilaelia virens é endêmica do Brasil, com distribuição conhecida para os estados da Região Sudeste (BFG 2015). Na etiqueta da exsicata examinada não constam informações acerca do habitat em que a planta foi encontrada, porém, de acordo com o que se conhece sobre a espécie, é de se esperar que ocorra em áreas de mata. Foi coletada florida em maio. Dentre as espécies encontradas para a SOB, distingue-se dos demais grupos morfologicamente próximos, como as espécies de Hadrolaelia e Hoffmannseggella, por ocorrer em área de mata, além de apresentar flores esverdeadas, semicerradas e com labelo alvo-esverdeado. 


\section{Brasilidium Campacci}

5.1. Brasilidium gravesianum (Rolfe) Campacci, Colet. Orquídeas Brasil. 3: 79. $2006 . \quad$ Fig. 3j

Epífita, 55-88 $\mathrm{cm}$ alt.. Crescimento simpodial. Raízes cilíndricas, cobertas por velame. Rizoma conspícuo, ca. 2,5-4 cm compr. Cauloma intumescido em pseudobulbo. Pseudobulbo heteroblástico, botuliforme, lateralmente achatado, 5-8 cm compr., 2(-3)-foliado. Folhas no ápice do pseudobulbo, suberetas a encurvadas, coriáceas, verdes, eventualmente com algumas máculas vináceas, elípticas a oblanceoladas, 10-22 × 2-4,4 cm, sésseis, ápice obtuso. Inflorescência lateral, em panícula, laxa, multiflora; pedúnculo 17-28 cm compr.; brácteas do pedúnculo deltoides, $8-12 \times 8-10 \mathrm{~mm}$, ápice obtuso; raque 27-60 cm compr.; brácteas florais triangulares, $2-4 \times 1,5-3$ $\mathrm{mm}$, ápice agudo. Flores castanho-amareladas, ressupinadas, pediceldas, ecalcaradas; sépala dorsal obovada, unguiculada, $2-2,2 \times 1,1-1,2$ $\mathrm{cm}$, ápice obtuso a arredondado; sépalas laterais coalescentes na base, ou até metade de seu comprimento, formando um sinsépalo, obovadas, falcadas, 2,2-2,8 × 0,8-0,9 cm, ápice agudo ou obtuso; pétalas largo-espatuladas, unguiculadas, 2,1-3 × 1,5-2,4 cm, ápice emarginado; labelo trilobado, âmbito largo-obovado, 2,4-3,2 × 2,4-3,1 $\mathrm{cm}$; calo complexo, basal, formado por saliências verrucosas e digitiformes, com uma protuberância central adunca; lobos laterais suborbiculares, 2-3 $\times$ 3-4 mm, ápice arredondado, margem inteira; lobo mediano unguiculado, depressamente obovado a transversalmente elíptico, 1,5-2 × 2,4-3,1 cm, ápice emarginado a profundamente emarginado, margem ondulada. Ginostêmio 9-10 mm compr.; antera apical, incumbente, vestásil; grãos de pólen aglutinados em polínias. Polínias 2, maciças, providas de estipe e viscídio. Ovário + pedicelo $2-3,3 \mathrm{~cm}$ compr. Fruto não visto.

Material examinado: área 3, 28.I.2003, fl. cult., C.C. de Paula et al. 621 (VIC); Sine loco, 17.III.2014, fl., T.L. Vieira 186 (SP); 17.III.2014, fl. cult. 25.III.2015, T.L. Vieira 259 (SP, BHCB); 6.XII.2013, fl. cult. 25.III.2015, T.L. Vieira 260 (SP).

Brasilidium gravesianum é endêmica do Brasil, com distribuição conhecida para os estados da Bahia, Paraíba, Pernambuco e das regiões Sudeste e Sul (BFG 2015). Na SOB foi encontrada em matas de galeria e capões de mata, acima dos $1.400 \mathrm{~m}$ de altitude. Floresce entre janeiro e março. Brasilidium foi proposto por Campacci (2006), a fim de elevar ao nível genérico as espécies de Oncidium Sw. seção Crispa Rchb.f. ex Pfitzer. Embora o reconhecimento do gênero seja relativamente fácil frente aos gêneros afins, a delimitação entre suas espécies ainda é muito subjetiva e pouco clara, tendo em vista que espécies como B. crispum (Lodd.) Campacci, $B$. praetextum (Rchb.f.) Campacci e o próprio $B$. gravesianum, por exemplo, são morfologicamente muito semelhantes. Fowlie (1976) comenta que as flores de $B$. crispum geralmente apresentam um odor fétido, característica não observada nos espécimes coletados na SOB. Dentre as espécies da família para a SOB, B. gravesianum pode ser identificada pela inflorescência em panícula, multiflora, portando flores predominantemente castanhas, maculadas de amarelo, com sépalas e pétalas unguiculadas, as últimas mais longas e largas que as primeiras, bem como pela calosidade do labelo, complexa e com uma grande projeção adunca.

\section{Bulbophyllum Thouars}

6.1. Bulbophyllum exaltatum Lindl., Ann. Mag. Nat. Hist. 10: 186. 1842.

Fig. 3k

Epífita, ca. $40 \mathrm{~cm}$ alt. Crescimento simpodial. Raízes filiformes, cobertas por velame. Rizoma conspícuo, ca. 2,5 cm compr. entre caulomas Cauloma intumescido em pseudobulbo. Pseudobulbo heteroblástico, ovoide, tetrágono em seção transversal, 2,5-3,5 cm compr., 1-foliado. Folha no ápice do pseudobulbo, ereta, carnosa, verde, elíptico-lanecolada, 6-9 × 2,7-2,9 cm, séssil, ápice obtuso. Inflorescência lateral, em racemo, laxa, ca. 18-flora; pedúnculo ca. 40 $\mathrm{cm}$ compr.; brácteas do pedúnculo amplectivas, adpressas, oblongas, $1,2-2 \times 0,3-0,5 \mathrm{~cm}$, ápice obtuso; raque ca. 10,5 cm compr.; brácteas florais lanceoladas, 7-10 × 2,5-3,5 mm, ápice agudo. Flores com cor de fundo variando do creme ao creme-esverdeado, com máculas vináceas, ressupinadas, pediceladas, ecalcaradas; sépala dorsal creme-esverdeada com máculas vináceas, triangular-lanceolada, 10-11 × 3-4 mm, ápice agudo; sépalas laterais creme-esverdeadas com máculas vináceas, livres, triangular-lanceoladas, muito levemente falcadas, $10-11 \times 3-4 \mathrm{~mm}$, ápice agudo; pétalas alvas maculadas de vináceo, lanceoladas, 3-3,5 × 1,5 mm, ápice agudo; labelo vináceo-escuro, unguiculado, articulado com o pé da coluna, trilobado, âmbito elíptico-lanceolado, 7-8 $\times 3-3,5 \mathrm{~mm}$, calo constituído por elevação longitudinal em todo o disco do labelo; lobos laterais suborbiculares, pilosos, 1,3-1,5 × 1-1,2 $\mathrm{mm}$, ápice arredondado, margem inteira, com tricomas bem evidentes em toda a superfície; lobo mediano ovado-elíptico, pubescente, ca. 4,3 
$\times 2,5 \mathrm{~mm}$, ápice arredondado, margem inteira, inconspicuamente pilosa, com tricomas mais conspícuos próximo à base. Ginostêmio $4-4,7 \mathrm{~mm}$ compr., ápice com par de antenas lineariformes de ca. 1,8-2,1 mm compr., base projetada formando pé de 1-2 mm compr.; grãos de pólen aglutinados em polínias. Polínias 4, maciças, nuas. Ovário + pedicelo ca. 4,5-5 mm compr. Fruto não visto.

Material examinado: porção da serra a oeste das antenas, 24.I.2014, fl. cult. 14.V.2015, T.L. Vieira 177 (SP).

Bulbophyllum exaltatum apresenta ampla distribuição na América do Sul, principalmente em áreas de altitude elevada, desde o Peru, Colômbia, Venezuela, Guianas e Brasil, onde é conhecida para os estados do Amazonas, Bahia, Goiás, Roraima, Santa Catarina e da Região Sudeste (Smidt 2007; BFG 2015; Govaerts et al. 2015). Na SOB foi encontrada como epífita em matas de galeria situadas no extremo oeste da serra. Floresceu em cultivo em abril. Dentre as demais espécies da família para a SOB, pode ser reconhecida por seus pseudobulbos heteroblásticos, tetrágonos, unifoliados e espaçados pelo longo rizoma, além da inflorescência lateral, portando flores cremeesverdeadas, maculadas de vináceo, com sépalas triangular-lanceoladas.

\section{Campylocentrum Benth.}

Ervas epífitas. Crescimento monopodial. Raízes filiformes, cobertas por velame. Caule não intumescido em pseudobulbo, multifoliado. Folhas alternas, dísticas, patentes, verdes, base amplexicaule, ápice geralmente assimetricamente retuso. Inflorescência axilar, em racemo, $\infty$-flora. Flores pediceladas, ressupinadas, calcaradas, membranáceas; sépalas livres entre si, as laterais geralmente um pouco mais longas que a dorsal, oblongas a lanceoladas, as laterais eventualmente falcadas; pétalas livres, elípticas a lanceoladas; labelo inteiro ou trilobado, provido de um calcar na base, ligado ao ginostêmio apenas na base. Ginostêmio cilíndrico, curto; antera incumbente, versátil; grãos de pólen aglutinados em polínias. Polínias 2, maciças, providas de estipe e viscídio.

\section{Chave de identificação para espécies de Campylocentrum ocorrentes na Serra do Ouro Branco}

1. Folhas $0,8-1,4 \times 0,2-0,3 \mathrm{~cm}$, lobos do ápice agudos; calcar clavado

1'. Folhas 2-4,5 × 0,4-1 cm, lobos do ápice obtusos; calcar fusiforme.

2. Campylocentrum pauloense

2. Calcar verde; sépala dorsal 2,5-3 mm compr.; sépalas laterais 3-3,5 mm compr., ligeiramente falcadas; pétalas ca. $3 \mathrm{~mm}$ compr.; labelo ca. $3,5 \times 2 \mathrm{~mm}$, ápice agudo

3. Campylocentrum spannagelii

2'. Calcar castanho; sépala dorsal 3,5-4 mm compr.; sépalas laterais ca. $4 \mathrm{~mm}$ compr., não falcadas; pétalas 3,5-4 mm compr.; labelo ca. $4 \times 2,5 \mathrm{~mm}$, ápice obtuso

1. Campylocentrum crassirhizum

7.1. Campylocentrum crassirhizum Hoehne, Arq. Bot. Estado São Paulo 1: 44. $1939 . \quad$ Fig. 4a Epífita, 9-11 cm alt. Folhas patentes, coriáceas, verdes, elípticas, 2-4,5 ×0,7-1,0 cm, lobos do ápice obtusos. Inflorescência subcongesta; pedúnculo inconspícuo; raque $7-10 \mathrm{~mm}$ compr.; brácteas deltoides, ca. 1,5 × 1,5 mm, ápice agudo. Flores alvas; calcar castanho, fusiforme, ca. $4 \mathrm{~mm}$ compr; sépala dorsal estreito-oblonga, 3,5-4 × $1 \mathrm{~mm}$, ápice acuminado; sépalas laterais oblongo-lanceoladas, ca. $4 \times 1 \mathrm{~mm}$, ápice agudo a acuminado; pétalas elípticas, 3,5-4 × $1 \mathrm{~mm}$, ápice agudo ou obtuso; labelo trilobado, âmbito ovado, ca. $4 \times 2,5 \mathrm{~mm}$, lobos laterais oblongos, ca. 1,5-2 $\times 1 \mathrm{~mm}$, ápice arredondado, margem inteira; lobo mediano lanceolado, ca. $2 \times 1 \mathrm{~mm}$, ápice obtuso, margem inteira. Ginostêmio ca. $2 \mathrm{~mm}$ compr. Ovário + pedicelo, ca. 2 mm compr. Fruto fusiforme, 7-9 × 1,5-2 mm.

Material examinado: Folha Larga, área de F.E.S. no sopé da serra na porção sudeste, 29.I.2015, fr., T.L. Vieira 243 (SP); 29.I.2015, fl., T.L. Vieira 245 (SP).

Campylocentrum crassirhizum é endêmica do Brasil, com distribuição conhecida para os estados de Alagoas, Bahia, Ceará, Mato Grosso do Sul, Paraíba, Paraná, Pernambuco, Rio Grande do Norte, Santa Catarina, Sergipe e Região Sudeste (BFG 2015; Pessoa et al. 2015). Na SOB foi encontrada em Floresta Estacional Semidecidual, principalmente na porção sudeste ao sopé da serra. Floresce em janeiro. A espécie é morfologicamente semelhante a $C$. spannagelii, sobretudo no aspecto vegetativo, mas pode ser reconhecida pelas folhas, em geral, mais largas (7-10 mm larg. vs. 4-6 mm 


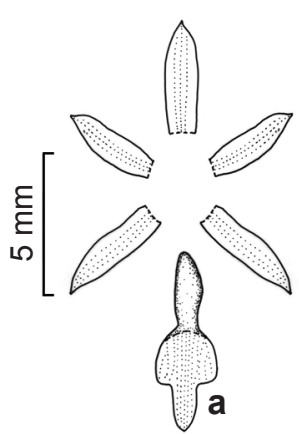
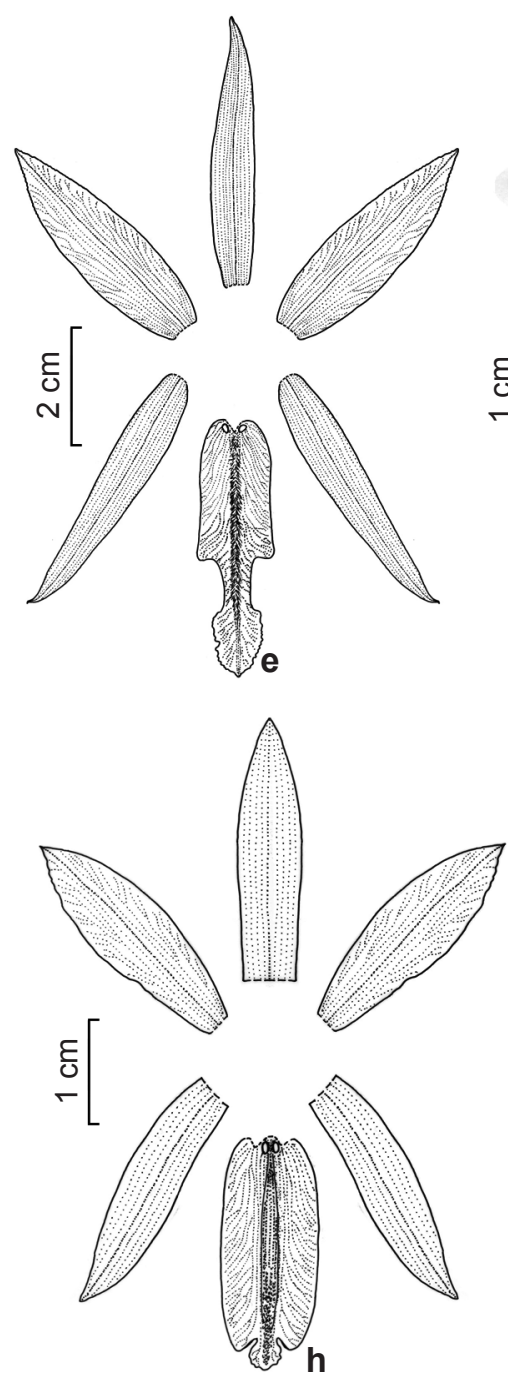

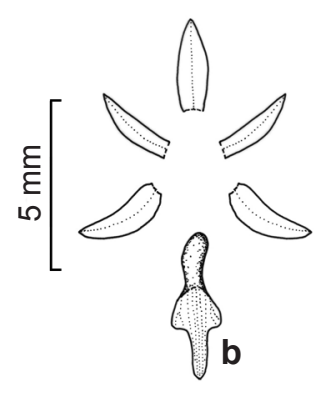<smiles>C=CC1CC=CCC1</smiles>

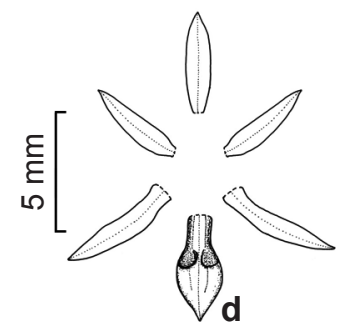
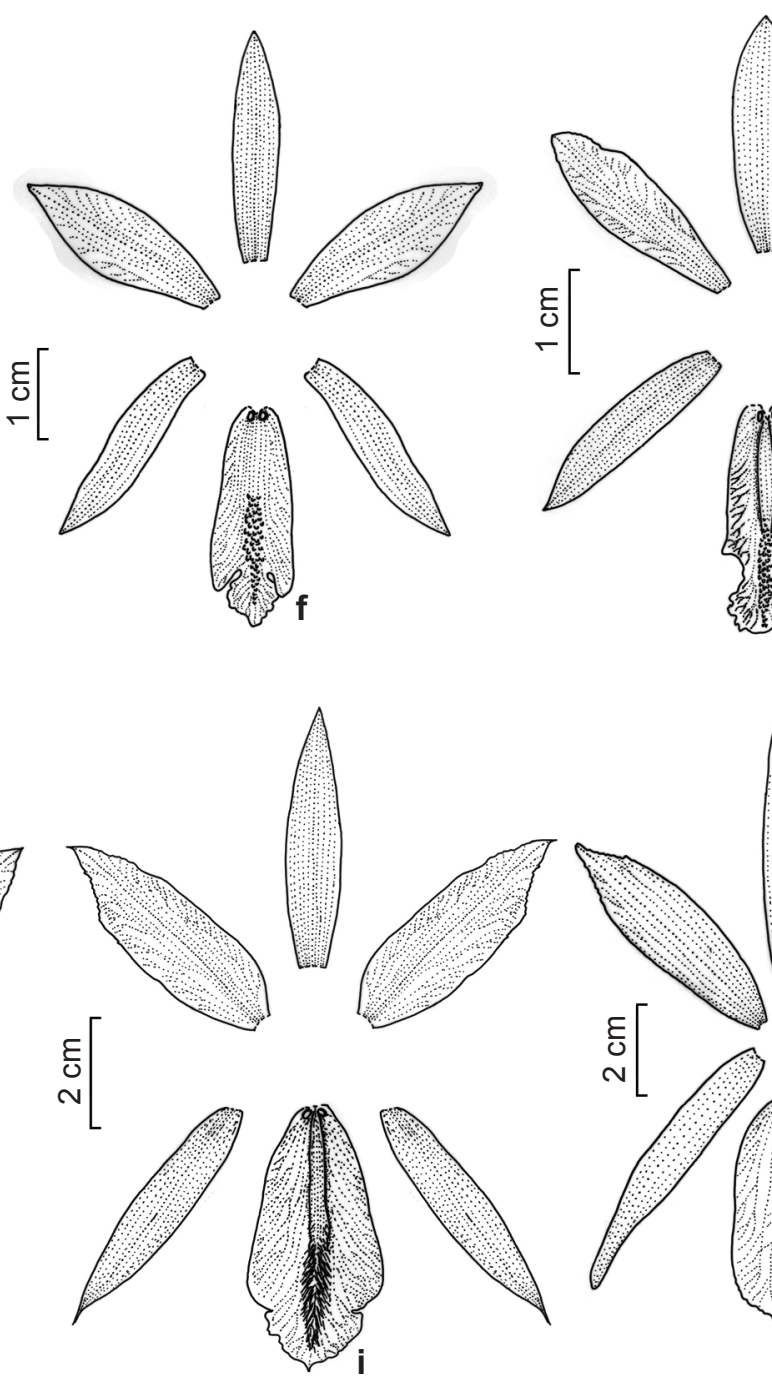

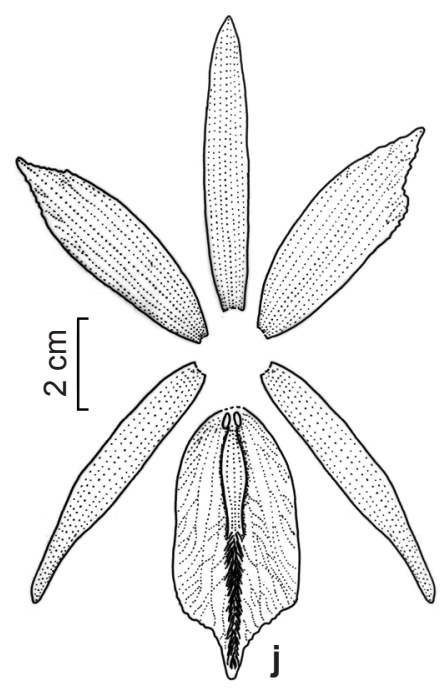

Figura 4 - Periantos dissecados. a. Campylocentrum crassirhizum (T.L. Vieira 245). b. Campylocentrum pauloense (T.L. Vieira 166). c. Campylocentrum spannagelii (T.L.Vieira 164). d. Capanemia thereziae (C.C. de Paula et al. 802). e. Cleistes bella (J.A.N. Batista 2622). f. Cleistes exilis (T.L. Vieira 173). g. Cleistes gracilis (T.L. Vieira 2615). h. Cleistes moritzii (J.M. Fernandes et al. 677). i. Cleistes paranaensis (G.G. Valente 1860). j. Cleistes rosea (T.L. Vieira 240).

Figure 4 - Dissected perianths. a. Campylocentrum crassirhizum (T.L. Vieira 245). b. Campylocentrum pauloense (T.L. Vieira 166). c. Campylocentrum spannagelii (T.L. Vieira 164). d. Capanemia thereziae (C.C. de Paula et al. 802). e. Cleistes bella (J.A.N. Batista 2622). f. Cleistes exilis (T.L. Vieira 173). g. Cleistes gracilis (T.L. Vieira 2615). h. Cleistes moritzii (J.M. Fernandes et al. 677). i. Cleistes paranaensis (G.G. Valente 1860). j. Cleistes rosea (T.L. Vieira 240). 
larg.), o lobo mediano do labelo apresentando ápice obtuso ( $v s$. agudo), além do calcar que é castanho (vs. verde). Esta última, a principal característica de distinção entre as espécies.

7.2. Campylocentrum pauloense Hoehne \& Schltr., Arq. Bot. Estado São Paulo 1: 197. 1926.

Fig. $4 \mathrm{~b}$

Epífita, 2-3,3 cm alt. Folhas patentes, coriáceas, carnosas, verdes, estreito-elípticas, $0,8-1,4 \times 0,2-0,3 \mathrm{~cm}$, lobos do ápice agudos. Inflorescência subcongesta; pedúnculo inconspícuo, raque 5-8 mm compr., brácteas deltoides, ca. $1 \times 1$ $\mathrm{mm}$, ápice agudo. Flores alvas; calcar esverdeado, curto-clavado, 1-2 mm compr.; sépala dorsal estreito-oblonga a lanceolada, 2,5-3 × $1 \mathrm{~mm}$, ápice acuminado; sépalas laterais lanceoladas a oblongas, ligeiramente falcadas, ca. $3 \times 1 \mathrm{~mm}$, ápice acuminado; pétalas elíptico-lanceoladas, ligeiramente falcadas, ca. $3 \times 1 \mathrm{~mm}$, ápice agudo; labelo trilobado, âmbito ovado, ca. $3 \times 1,5-2 \mathrm{~mm}$, lobos laterais oblongos, ca. $1-5 \times 1 \mathrm{~mm}$, ápice arredondado, margem inteira, lobo mediano lanceolado a subtriangular, ca. 1-1,5 × $1 \mathrm{~mm}$, ápice obtuso, margem inteira. Ginostêmio ca. 1 $\mathrm{mm}$ compr. Ovário + pedicelo ca. $2 \mathrm{~mm}$ compr. Fruto não visto.

Material examinado: fragmento de FES na porção sudeste da serra, no sopé, 5.XII.2013, fl. cult. 5.XI.2014, T.L. Vieira 165 (SP); 5.XII.2013, fl., T.L. Vieira 166 (SP).

Campylocentrum pauloense tem distribuição conhecida para os estados das regiões Sudeste e Sul do Brasil (exceto Paraná), alcançando o norte da Argentina (BFG 20015; Govaerts et al. 2015). Na SOB foi encontrada em Floresta Estacional Semidecidual na porção sudeste ao sopé da serra. Floresce entre novembro e dezembro. Dentre as espécies do gênero ocorrentes na área de estudo pode ser reconhecida pelo tamanho muito reduzido das folhas $(0,8-1,4 \times 0,2-0,3 \mathrm{~cm})$, com lobos do ápice agudos, o que confere um aspecto diminuto à planta, além do calcar que é clavado, enquanto C. crassirhizum e C. spannagelii apresentam calcar fusiforme.

7.3. Campylocentrum spannagelii Hoehne, Arq. Bot. Estado São Paulo 1: 22. $1938 . \quad$ Fig. 4c

Epífita, ca. $5 \mathrm{~cm}$ alt. Folhas patentes, coriáceas, verdes, estreito-elípticas, 2,4-3,2 $\times$ 0,4-0,6 cm, lobos do ápice obtusos. Inflorescência ca. $11 \mathrm{~mm}$ compr., subcongesta; pedúnculo inconspícuo; raque 9-10 $\mathrm{mm}$ compr.; brácteas deltoides, ca. $1 \times 1,5 \mathrm{~mm}$, ápice agudo. Flores alvas; calcar esverdeado, fusiforme, 3,5-4 mm compr.; sépala dorsal lanceolada, 2,5-3 × 1 $\mathrm{mm}$, ápice agudo a acuminado; sépalas laterais oblongo-lanceoladas, ligeiramente falcadas, 3-3,5 × $1 \mathrm{~mm}$, ápice agudo a acuminado; pétalas elíptico-lanceoladas, ligeiramente falcadas, ca. $3 \times 1 \mathrm{~mm}$, ápice agudo; labelo trilobado, âmbito ovado, ca. 3,5 $\times 2 \mathrm{~mm}$, lobos laterais oblongos, ca. 1,5-2 $\times 1 \mathrm{~mm}$, ápice arredondado, margem inteira, lobo mediano subtriangular, ca. 1,5-2 $\times 1$ $\mathrm{mm}$, ápice agudo, margem inteira. Ginostêmio ca. $1 \mathrm{~mm}$ compr. Ovário + pedicelo ca. $2 \mathrm{~mm}$ compr. Fruto não visto.

Material examinado: fragmento de FES na porção sudeste da serra, no sopé, 5.XII.2013, fl. cult. 6.II.2014, T.L. Vieira 164 (SP).

Campylocentrum spannagelii é endêmica do Brasil, com distribuição conhecida para os estados das regiões Sudeste e Sul (exceto Rio Grande do Sul) (BFG 2015). Na SOB foi encontrada em Floresta Estacional Semidecidual. Floresceu em cultivo em fevereiro. Ver comentários em $C$. crassrhizum.

\section{Capanemia Barb.Rodr.}

8.1. Capanemia thereziae Barb.Rodr., Gen Sp. Orchid. 2: 244. 1887.

Fig. 4d

Epífita, 3,5-4,5 $\mathrm{cm}$ alt. Crescimento simpodial. Raízes filiformes, cobertas por velame. Rizoma inconspícuo. Cauloma intumescido em pseudobulbo. Pseudobulbo heteroblástico, ovoide, não formando ângulos em seção transversal, coberto por bainhas escariosas, 5-9 mm compr., 1-foliado. Folha no ápice do pseudobulbo, ereta a subereta, coriácea, verde, linear, 18-33 × 2-3,5 mm, séssil, ápice agudo. Inflorescência lateral, em racemo, laxa, pauciflora; pedúnculo $1,2-1,5 \mathrm{~cm}$ compr.; bráctea do pedúnculo, oblonga, amplectiva, escariosa, 4-5 × 1,5-2 mm, ápice obtuso; raque 7-9 mm compr., brácteas florais ovadas, escariosas, 2,5-4 × 1,5-2 mm, ápice agudo. Flores esverdeadas, ressupinadas, pediceladas, ecalcaradas; sépala dorsal elíptico-lanceoladas, 4-5 $\times 1 \mathrm{~mm}$, ápice agudo; sépalas laterais livres entre si, oblongo-lanceoladas, ligeiramente falcadas, 4-6 $\times 1 \mathrm{~mm}$, ápice agudo; pétalas lanceoladas, $4-5 \times$ $1 \mathrm{~mm}$, ápice agudo; labelo inteiro, oblanceolado, $5 \times 1,5-2 \mathrm{~mm}$, calosidade formada por duas lamelas longitudinais da base até cerca de metade do comprimento do labelo, ápice agudo, margem inteira. Ginostêmio 1,5-2 mm compr.; antera apical, incumbente, versátil; grãos de pólen aglutinados em polínias. Polínias 2, maciças, 
providas de estipe e viscídio. Ovário + pedicelo 3,5-7 mm compr. Fruto não visto.

Material examinado: área 2, 18.V.2003, fl., C.C. de Paula et al. 802 (VIC).

Capanemia thereziae é endêmica do Brasil, com distribuição conhecida para os estados da Bahia, Pernambuco e das regiões Sudeste e Sul (BFG 2015). Na SOB foi encontrada em mata de galeria, florescendo em maio. Pode ser reconhecida por ser uma epífita de tamanho reduzido $(3,5-4,5$ $\mathrm{cm}$ alt.), pseudobulbo heteroblástico, geralmente recoberto por bainhas escariosas, com apenas uma única folha apical, inflorescência lateral, em racemo, e flores esverdeadas com labelo inteiro e calosidade formada por duas lamelas longitudinais.

\section{Cleistes Rich. ex Lindl.}

Ervas terrícolas. Raízes filiformes, algumas portando tuberoides. Rizoma subterrâneo, inconspícuo. Caule aéreo ereto, não intumescido em pseudobulbo, produzido apenas no período reprodutivo, desaparecendo após a deiscência dos frutos. Folhas alternas, espiraladas, evidentes ou não, comumente glaucas, verdes a vináceas, venação paralelinérvea, base amplexicaule. Inflorescência terminal, uniflora ou em racemo 2-4-floro. Flores pediceladas, ressupinadas, ecalcaradas, calículo ausente, comumente vistosas, vináceas a alvas, membranáceas; sépalas livres entre si, dorsal e laterais de forma e tamanho semelhantes; pétalas livres, geralmente mais largas que as sépalas; labelo inteiro ou trilobado, base com um par de glândulas nectaríferas, crista central papilosa ou fimbriada, margem comumente ondulada, lobo mediano em geral unguiculado. Ginostêmio claviforme; antera incumbente, versátil; grãos de pólen livres, em mônades ou tétrades, não formando polínias verdadeiras; superfície estigmática plana ou côncava; zona de abscisão entre perianto e ovário presente. Zona de abscisão entre pedicelo e ovário ausente. Fruto cápsula.

\section{Chave de identificação para espécies de Cleistes ocorrentes na Serra do Ouro Branco}

1. Labelo com crista central fimbriada.

2. Folhas elípticas a ovadas, $(1,5-) 1,8-3,2 \mathrm{~cm}$ larg.; labelo unguiculado, istmo $4-8 \mathrm{~mm}$ compr. ...... 1. Cleistes bella

2'. Folhas lanceoladas a elíptico-lanceoladas, $0,7-1,2 \mathrm{~cm}$ larg.; labelo não unguiculado, istmo ausente.

3. Folhas da porção mediana do caule eretas; labelo inteiro, de âmbito elíptico6. Cleistes rosea

3'. Folhas da porção mediana do caule suberetas; labelo trilobado, de âmbito obovado

5. Cleistes paranaensis

1'. Labelo com crista central papilosa.

4. Plantas ca. $14 \mathrm{~cm}$ alt.; labelo inconspicuamente trilobado, não unguiculado

7. Cleistes tenuis

4'. Plantas $25,5-86 \mathrm{~cm}$ alt.; labelo conspicuamente trilobado, unguiculado.

5. Plantas $75-86 \mathrm{~cm}$ alt., com aspecto áfilo; folhas reduzidas, eretas e adpressas ao caule; lobo mediano do labelo deltoide

2. Cleistes exilis

5'. Plantas 25,5-42 cm alt, evidentemente foliadas; folhas desenvolvidas, apenas as da base do caule eretas, as demais ereto-patentes; lobo mediano do labelo suborbicular.

6. Labelo com vênulas escuras; istmo ca. $3 \times 4 \mathrm{~mm}$; porção apical do lobo mediano ca. 6 $\times 8 \mathrm{~mm}$ 3. Cleistes gracilis

6'. Labelo sem vênulas escuras; istmo inconspícuo; porção apical do lobo mediano 2-3 $\times$ $3 \mathrm{~mm}$ 4. Cleistes moritzii

9.1. Cleistes bella Rchb.f. \& Warm., Otia Bot. Hamburg. 2: 81. 1881. Fig. $4 \mathrm{e}$

Terrícola, 23,5-29 cm alt. Folhas suberetas, cartáceas, elípticas a ovadas, menos comumente lanceoladas, 3-8(-12,5) × (1,5-) 1,8-3,2 cm, ápice agudo a acuminado. Inflorescência 1-2-flora; pedúnculo 2,5-5,5 cm compr., raque ca. $2 \mathrm{~cm}$ compr. quando presente; brácteas elípticas ou, menos comumente, estreito-elípticas, 4,5-7(-9,5) $\times$ (1-)1,4-2 cm, ápice agudo. Flores róseo-vináceas; sépala dorsal lanceolada, ca. 4,5 ×0,7 cm, ápice agudo; sépalas laterais lanceoladas, ca. 4,5 × 0,7 $\mathrm{cm}$, ápice agudo; pétalas elíptico-lanceoladas, ca. $4,1 \times 1,2 \mathrm{~cm}$, margem erosa próximo ao ápice, ápice agudo; labelo trilobado, âmbito oblongo, ca. 4,3 $\times 1,3 \mathrm{~cm}$, crista central fimbriada, vênulas 
escuras presentes, lobos laterais subfalcados, 2,4 $\times 0,5 \mathrm{~cm}$, margem inteira, ápice arredondado, lobo mediano unguiculado, istmo ca. $8 \times 4 \mathrm{~mm}$, porção apical elíptica, ca. 1,2 ×0,8 cm, margem erosa, ápice obtuso. Ginostêmio ca. $2 \mathrm{~cm}$ compr. Pedicelo + ovário 2,2 cm compr. Fruto não visto.

Material examinado: ca. $10 \mathrm{~km}$ do entroncamento com a MG-433, no entorno do cume da serra, 5.III.2008, fl., J.A.N. Batista 2622 (BHCB).

Cleistes bella é endêmica do Brasil, com distribuição conhecida para os estados de Goiás, Mato Grosso e Minas Gerais, além do Distrito Federal (BFG 2015). Na SOB foi encontrada em campo limpo estacionalmente úmido. Floresce em março. Pode ser reconhecida pelo porte mediano (23,5-29 $\mathrm{cm}$ alt.), associado às folhas bem desenvolvidas, entrenós geralmente curtos, flores grandes e róseo-vináceas, com labelo unguiculado e de istmo longo (ca. $8 \mathrm{~mm}$ compr.), além de toda a planta tornar-se fortemente enegrecida quando herborizada.

9.2. Cleistes exilis Hoehne, Relat. Com. Lin. Telegr., Bot. 9: 26, t. 167, fig. 1. 1916. Fig. 4f Terrícola, 75-86 cm alt. Folhas eretas, adpressas ao caule, cartáceas, ovado-lanceoladas, 0,9-1,2 × 0,3-0,4 cm, ápice obtuso. Inflorescência 3-4-flora; pedúnculo 12,5-16,5 cm compr., raque 6-10 cm compr., brácteas ovado-lanceoladas a elíptico-lanceoladas, 0,6-1,2 × 0,3-0,4 cm, ápice obtuso. Flores róseo-pálidas; sépala dorsal estreitoelíptica, ca. 2,5 ×0,5 cm, ápice agudo; sépalas laterais estreito-elípticas, 2,5 × 0,4-0,5 cm, ápice agudo; pétalas elípticas a oblanceoladas, falcadas, $2,4 \times 0,7-0,8 \mathrm{~cm}$, margem inteira, ápice obtuso; labelo trilobado, âmbito oblanceolado, ca. 2,4 × $0,9 \mathrm{~cm}$, crista central papilosa, vênulas escuras ausentes, lobos laterais falcados, margem inteira, ápice arredondado, lobo mediano unguiculado, istmo inconspícuo, porção apical deltoide, ca. $5 \times$ $6 \mathrm{~mm}$, margem ondulada, ápice obtuso. Ginostêmio ca. 1,4 cm compr. Pedicelo + ovário 2,4-3,3 cm compr. Fruto não visto.

Material examinado: próximo ao extremo oeste da serra, 24.I.2014, fl., T.L. Vieira 173 (SP, BHCB).

Cleistes exilis é endêmica do Brasil, com distribuição conhecida para os estados da Bahia, Goiás e Minas Gerais (BFG 2015). Na SOB foi encontrada em campo sujo, em declive no extremo oeste da serra. Floresce em janeiro. Facilmente reconhecida pelo caule delgado e delicado, com folhas extremamente reduzidas e completamente adpressas, além do labelo trilobado, unguiculado e com lobo mediano deltoide.
9.3. Cleistes gracilis (Barb.Rodr.) Schltr., Arch. Bot. São Paulo 1: 179. 1926.

Fig. $4 \mathrm{~g}$

Terrícola, 25,5-34 cm alt. Folhas suberetas a subpatentes, membranáceas, lanceoladas a elípticas, as da base reduzidas, 1,3-5 × 0,5-1,4 cm, ápice agudo a acuminado. Inflorescência 1-2-flora; pedúnculo 8-9,5 cm compr., raque $1-5 \mathrm{~cm}$ compr., quando presente; brácteas elípticas, 3-4 × 1,2-1,5 $\mathrm{cm}$, ápice acuminado. Flores róseas; sépala dorsal estreito-elíptica, 2,4-2,8 × 0,6-0,8 cm, ápice agudo; sépalas laterais oblongo-lanceoladas a estreitoelípticas, 2,4-2,7 ×0,5-0,6 cm, ápice agudo; pétalas elípticas a estreito-obovadas, falcadas, 2,3-2,6 $\times$ 0,7-0,9 cm, margem erosa próximo ao ápice, ápice obtuso; labelo trilobado, âmbito oblongo, 2,3-2,5 $\times 0,8 \mathrm{~cm}$, crista central papilosa, vênulas escuras presentes, lobos laterais subtriangulares, margem inteira, ápice obtuso, lobo mediano unguiculado, istmo $3 \times 4 \mathrm{~mm}$, porção apical suborbicular, ca. $6 \times$ $8 \mathrm{~mm}$, margem ondulada, ápice obtuso. Ginostêmio ca. 1,3 cm compr. Pedicelo + ovário ca. $1,8 \mathrm{~cm}$ compr. Fruto não visto.

Material examinado: ca. $7 \mathrm{~km}$ do entroncamento com a MG-443, 5.III.2008, fl., J.A.N. Batista 2615 (BHCB).

Cleistes gracilis é endêmica do Brasil, com distribuição conhecida para os estados da Bahia, Paraná e da Região Sudeste (BFG 2015). Na SOB foi encontrada em campo limpo estacionalmente úmido. Floresce em março. Assemelha-se vegetativamente a $C$. moritzii pelas folhas basais pouco desenvolvidas em relação às demais, que são bem desenvolvidas e suberetas, elípticas a elípticolanceoladas, mas é facilmente identificável pela morfologia do labelo, que é trilobado, com istmo desenvolvido e largo, além de apresentar vênulas escuras ao longo de toda sua extensão.

\subsection{Cleistes moritzii (Rchb.f.) Garay \& Dunst.,} Venez. Orchid. Ill. 1(4): 54. $1966 . \quad$ Fig. 4h

Terrícola, 27-42 cm alt. Folhas suberetas, membranáceas, lanceoladas a elípticas, as da base reduzidas, 1,6-5 × 1-2 cm, ápice agudo. Inflorescência 3-4-flora; pedúnculo $6,5-7,5 \mathrm{~cm}$ compr., raque 10-15,5 cm compr.; brácteas elípticas, 2,3-5,5 × 1-2,1 cm, ápice agudo a acuminado. Flores róseas; sépala dorsal oblongo-lanceolada a lanceolada, ca. 2,5 ×0,5 cm, ápice agudo; sépalas laterais oblongo-lanceoladas, 2,3-2,4×0,4-0,5 cm, ápice agudo; pétalas elípticas a estreito-obovadas, levemente falcadas, 2,3-2,4 × 0,6-0,7 cm, margem, em geral, levemente sinuada próximo ao ápice, ápice acuminado; labelo trilobado, âmbito oblongo, ca. 2,2 $\times 0,9 \mathrm{~cm}$, crista central papilosa, vênulas 
escuras ausentes, lobos laterais arredondados, margem inteira, ápice arredondado, lobo mediano unguiculado, istmo inconspícuo, porção apical suborbicular, $2-3 \times 3 \mathrm{~mm}$, margem ondulada, ápice obtuso. Ginostêmio 1,7-2 cm compr. Pedicelo + ovário 2-2,5 cm compr. Fruto terete, ca. 2,5 cm compr.

Material examinado: RPPN Gerdau AçoMinas, 23.II.2008, fl., fr., J.M. Fernandes et al. 677 (VIC).

Cleistes moritzii tem distribuição conhecida para os estados do Amazonas, Bahia, e Região Sudeste, ocorrendo também na Colômbia, Guiana, Equador e Venezuela (BFG 2015; Govaerts et al. 2015). Na SOB foi encontrada na área da RPPN Gerdau, que abrange o declive da serra e áreas de mata em sua face sudoeste. Floresce em fevereiro. Cleistes moritzii e C. gracilis são similares vegetativamente, mas a primeira apresenta o labelo trilobado, unguiculado, com istmo inconspícuo e lobo mediano reduzido, se comparado ao de $C$. gracilis, e sem vênulas escuras.

9.5. Cleistes paranaensis (Barb.Rodr.) Schltr., Arch. Bot. São Paulo 1: 180. 1926.

Fig. $4 \mathrm{i}$

Terrícola, 42,5-90 cm alt. Folhas da base eretas, adpressas ao caule, as demais suberetas, membranáceas, lanceoladas, 3,6-9,5 × 0,8-1,2 $\mathrm{cm}$, ápice agudo a longamente acuminado. Inflorescência 1-3-flora; pedúnculo 11-14,5 cm compr., raque 4-12 cm compr., quando presente; brácteas lanceoladas a estreito-ovadas, $2-8,5 \times$ 0,4-1,1 cm, ápice agudo a longamente acuminado. Flores róseo-pálidas a róseo-vináceas; sépala dorsal estreito-elíptica, 4,7-5,5 ×0,9 cm, ápice agudo a apiculado; sépalas laterais estreito-elípticas, 5,5-5,7 $\times 0,9-1,0 \mathrm{~cm}$, ápice longamente apiculado; pétalas oblongo-elípticas, 4,7-5,5 × 1,5-1,8 cm, margem sinuada próximo ao ápice, ápice acuminado; labelo lilás, trilobado, âmbito obovado, 4,8-5,3 × 2,5 cm, crista central fimbriada, vênulas escuras presentes, lobos laterais arredondados, margem ondulada, ápice arredondado, lobo mediano não unguiculado, semicircular, istmo ausente, 1,2-1,5 × 1,8-2,3 $\mathrm{cm}$, margem ondulada, ápice obtuso. Ginostêmio 2,3-2,5 cm compr. Pedicelo + ovário 1,9-2,2 cm compr. Fruto não visto.

Material examinado: margem da estrada que corta a serra, 1.III.2001, fl., A.N. Caiafa \& L.D. Meireles 101 (VIC); Sine loco, 19.I.2007, fl., G.E. Valente 1860 (VIC, SP); ca. $7 \mathrm{~km}$ do entroncamento com a MG-443, 5.III.2008, fl., J.A.N. Batista 2614 (BHCB); Sine loco, 23.I.2014, fl., T.L. Vieira 172 (SP); próximo ao extremo oeste da serra, 24.I.2014, fl., T.L. Vieira 174 (SP); 24.I.2014, fl., T.L. Vieira 175 (SP).
Cleistes paranaensis é endêmica do Brasil, com distribuição conhecida para os estados da Bahia, Goiás, Minas Gerais, Paraná, Rio de Janeiro, Santa Catarina e São Paulo, além do Distrito Federal (BFG 2015). Cleistes paranaensis foi a espécie do gênero mais abundantemente encontrada na SOB, ocorrendo em campo limpo e campo limpo associado a campo rupestre. Foi observada florida durante o período chuvoso, principalmente entre janeiro e março. Pode ser reconhecida pelo caule, em geral levemente sinuoso, com folhas das porções mediana e apical suberetas, bem como pelas grandes flores, com labelo trilobado de âmbito obovado e crista central fimbriada.

9.6. Cleistes rosea Lindl., Gen Sp. Orch. Pl.: 410. 1840.

Fig. $4 \mathrm{j}$

Terrícola, 32-34 $\mathrm{cm}$ alt. Folhas eretas, as da base adpressas ao caule, membranáceas, lanceoladas a elíptico-lanceoladas, 1,9-6,5 × $0,7-1,1 \mathrm{~cm}$, ápice obtuso. Inflorescência uniflora; pedúnculo $8-8,5 \mathrm{~cm}$ compr.; bráctea lanceolada a elíptico-lanceolada, 5,4-5,9 × 1-1,2 cm, ápice obtuso. Flor castanho-lilás; sépala dorsal linearlanceolada, ca. 6,5-6,8 $\times 0,7-1 \mathrm{~cm}$, ápice obtuso; sépalas laterais estreito-elípticas, $6,5-6,8 \times 0,7-1,1$ $\mathrm{cm}$, ápice obtuso; pétalas estreito-elípticas a elípticas, ca. 5,9 × 1,2-1,8 cm, margem recortada próximo ao ápice, ápice obtuso; labelo inteiro, âmbito elíptico, 6,3-6,4 ×2,2-2,9 cm, crista central fimbriada, vênulas escuras ausentes, porção apical triangular, margem erosa, ondulada, ápice obtuso. Ginostêmio 2,9-3,7 cm compr. Pedicelo + ovário 2,5-3,4 cm compr. Fruto não visto.

Material examinado: Sine loco, 1916, fl., C. Porto 505 (RB); porção oeste da serra, 28.I.2015, fl., T.L. Vieira 240 (SP).

Cleistes rosea é uma espécie com ampla distribuição entre as regiões tropicais da América do Sul e a América Central (Govaerts et al. 2015); no Brasil foi registrada para os estados do Amazonas, Bahia, Goiás, Maranhão, Mato Grosso, Minas Gerais, Pará, Paraná, Rio de Janeiro, Roraima e São Paulo, além do Distrito Federal (BFG 2015). Foi encontrada florida em janeiro. Pode ser diferenciada das demais encontradas na SOB, pelas folhas eretas e bem desenvolvidas, inflorescência geralmente uniflora, cuja bráctea floral é geralmente de mesmo tamanho ou maior que a maior folha, protegendo todo o pedicelo + ovário, além das flores grandes (sépalas 6,5-6,8 $\mathrm{cm}$ compr.), com labelo inteiro, de âmbito elíptico e crista central fimbriada. 
9.7. Cleistes tenuis (Rchb.f. ex Griseb.) Schltr., Arch. Bot. São Paulo 1: 180. $1926 . \quad$ Fig. 5a

Terrícola, ca. $14 \mathrm{~cm}$ alt. Folhas suberetas, as da base eretas e reduzidas, membranáceas, estreito-lanceoladas, $0,6-1,1 \times 0,2-0,3 \mathrm{~cm}$, ápice agudo. Inflorescência 2-flora; pedúnculo 3,1-3,7 cm compr.; raque ca. $1,5 \mathrm{~cm}$ compr.; brácteas linear-lanceoladas $1-1,5 \times 0,1-0,2 \mathrm{~cm}$, ápice agudo. Flores predominantemente alvas; sépala dorsal estreito-elíptica, ca. $1,1 \times 0,2 \mathrm{~cm}$, ápice agudo; sépalas laterais estreito-elípticas, ca. 1,2 $\times 0,2 \mathrm{~cm}$, ápice agudo; pétalas estreito-obovadas, falcadas, ca. $1 \times 0,3 \mathrm{~cm}$, margem inteira, ápice obtuso; labelo inconspicuamente trilobado, âmbito elíptico, ca. $1 \times 0,5 \mathrm{~cm}$, crista central papilosa, vênulas escuras presentes, lobos laterais arredondados, margem inteira, ápice arredondado, lobo mediano não unguiculado, semicircular, ca. $2 \times 3 \mathrm{~mm}$, istmo ausente, margem ondulada, ápice obtuso. Ginostêmio ca. 6 mm compr. Pedicelo + ovário ca. $7 \mathrm{~mm}$ compr. Fruto não visto.

Material examinado: área 2, 19.I.2003, fl., C.C. de Paula et al. 596 (VIC).

Cleistes tenuis tem distribuição conhecida para os estados do Amazonas, Goiás, Mato Grosso, Minas Gerais e Paraná, além do Distrito Federal, ocorrendo também na Colômbia, Guiana, Guiana Francesa, Suriname e Trindad e Tobago (BFG 2015; Govaerts et al. 2015). Na SOB foi encontrada em campo limpo, com solo arenoso. Foi encontrada florida em janeiro. Espécie facilmente reconhecível, dentre as demais do gênero, pelo tamanho reduzido (ca. $14 \mathrm{~cm}$ alt.), flores pequenas e de coloração predominantemente alva.

\section{Comparettia Poepp. \& Endl.}

10.1. Comparettia coccinea Lindl., Edwads's Bot. Reg. 24: t. 68. 1838.

Fig. $5 b$

Epífita, ca. $30 \mathrm{~cm}$ alt. com a inflorescência. Crescimento simpodial. Raízes filiformes, cobertas por velame. Rizoma inconspícuo. Cauloma intumescido em pseudobulbo. Pseudobulbo heteroblástico, cilíndrico, ca. 2,3 cm compr., 1-foliado. Folha no ápice do pseudobulbo, subereta, coriácea, verde, estreito-elíptica, ca. 9,2 × 1,1 $\mathrm{cm}$, séssil, ápice agudo. Inflorescência lateral, em racemo, laxa, ca. 7-flora; pedúnculo ca. 23 $\mathrm{cm}$ compr., brácteas do pedúnculo deltoides a triangulares, 4-5 × 1,5-2,5 $\mathrm{mm}$, ápice agudo a acuminado; raque ca. $7 \mathrm{~cm}$ compr., brácteas florais triangulares, 2-3,5 × 1-2 mm, ápice agudo. Flores alaranjadas a avermelhadas, ressupinadas, pediceladas, calcaradas; calcar curvado, 1,3-1,5 cm compr.; sépala dorsal oblonga, ca. $8 \times 3 \mathrm{~mm}$, ápice acuminado; sépalas laterais coalescentes em toda sua extensão, formando um sinsépalo sagitiforme, 6-7 $\times 5-7 \mathrm{~mm}$, ápice obtuso, base prolongada formando o calcar; pétalas oblongas, 7-8 × 3,5 $\mathrm{mm}$, ápice obtuso a acuminado; labelo unguiculado, bilobado, âmbito depressamente largo-obovado, $1,4-1,6 \times 1,4-1,5 \mathrm{~mm}$, calosidade amarela formada por duas pequenas lamelas longitudinais, na base do labelo, base prolongada em duas antenas filiformes que se inserem no calcar; lobos transversalmente elípticos, $5 \times 9-10 \mathrm{~mm}$, ápice arredondado, margem erosa. Ginostêmio 5-7 mm compr., base não projetada em pé; antera apical, incumbente, versátil; grãos de pólen aglutinados em polínias. Polínias 2, maciças, providas de estipe e viscídio. Ovário + pedicelo 1,4-1,7 cm compr. Fruto não visto.

Material examinado: Sine loco, 14.IX.2013 fl. cult. 2.III.2015, T.L. Vieira et al. 156 (SP).

Comparettia coccinea possui distribuição conhecida para a Venezuela, Peru, Bolívia e Brasil, onde foi registrada nos estados da Bahia, Pernambuco e da Região Sudeste, além do Distrito Federal (BFG 2015; Govaerts et al. 2015). Na SOB foi encontrada em mata de galeria. Floresceu em cultivo em março. Comparettia coccinea é facilmente reconhecível pelas flores de coloração alaranjada a avermelhada, com as sépalas laterais coalescentes em toda sua extensão e formando, na base, um calcar longo e curvado.

\section{Coppensia Dumort.}

11.1. Coppensia blanchetii (Rchb.f.) Campacci, Bol. CAOB 62: 55. 2006.

Fig. 5c

Terrícola ou saxícola, $108-158 \mathrm{~cm}$ alt. com a inflorescência. Crescimento simpodial. Raízes filiformes, cobertas por velame. Rizoma inconspícuo. Cauloma intumescido em pseudobulbo. Pseudobulbo heteroblástico, ovoide, lateralmente achatado, 7-8 cm compr., 3-foliado. Folhas no ápice do pseudobulbo, suberetas a encurvadas, coriáceas, verdes, estreito-elípticas, $31-43,5 \times 1,4-2,8 \mathrm{~cm}$, sésseis, ápice agudo. Inflorescência lateral, em panícula, laxa, multiflora; pedúnculo 87,5-128,5 cm compr.; brácteas do pedúnculo deltoides, $0,8-1,8$ $\times 0,8-1,8 \mathrm{~cm}$, ápice obtuso a agudo; raque $18-38$ $\mathrm{cm}$ compr., brácteas florais deltoides a triangulares, 2-5 × 1,5-3 mm, ápice agudo. Flores amarelas maculadas de castanho, ressupinadas, pediceladas, ecalcaradas; sépala dorsal oblanceolada, unguiculada, ca. $6 \times 3 \mathrm{~mm}$, ápice obtuso; sépalas laterais coalescentes na base formando um sinsépalo, oblanceoladas, falcadas, ca. $7 \times 2,5 \mathrm{~mm}$, 


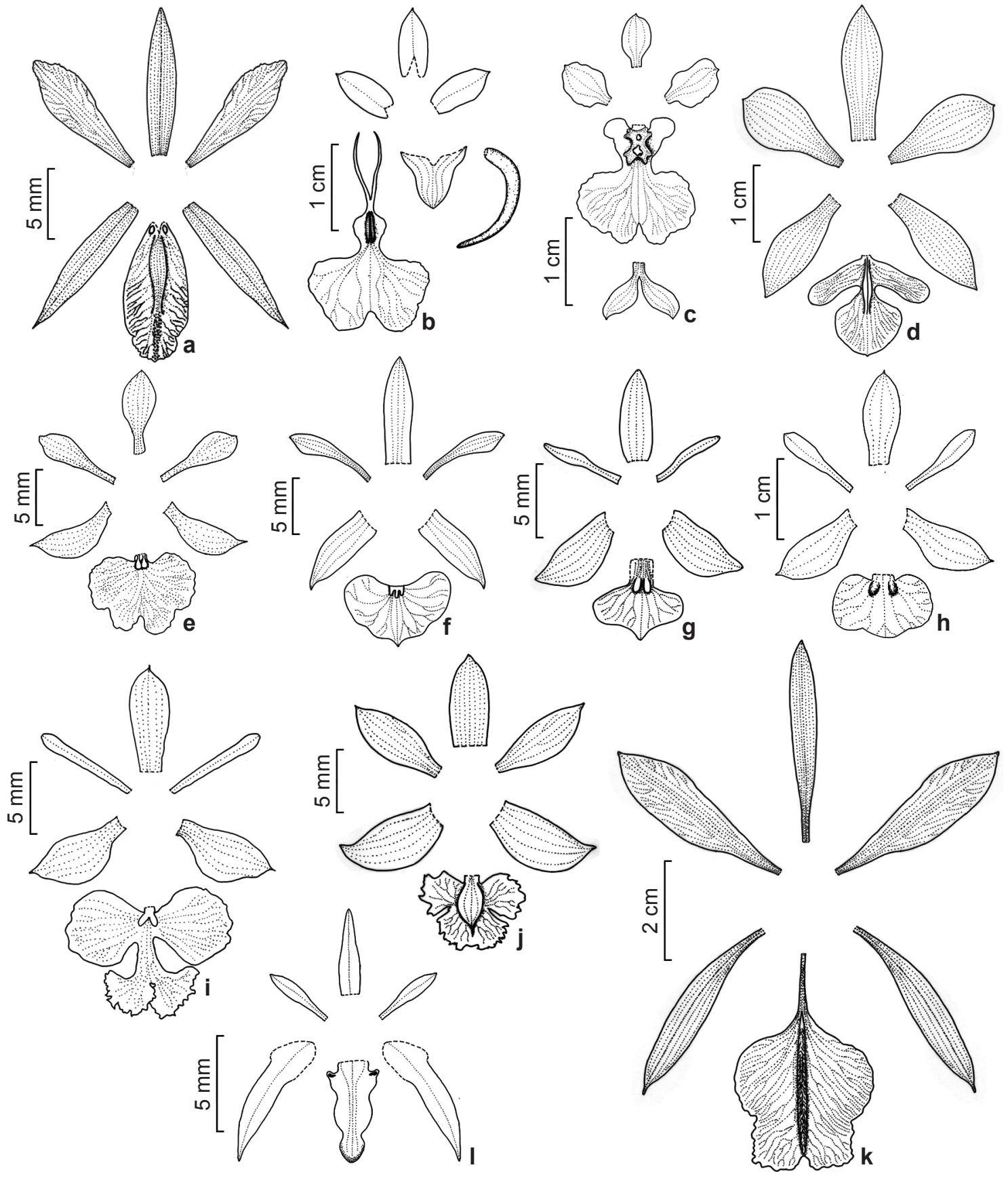

Figura 5 - Periantos dissecados. a. Cleistes tenuis (de Paula et al. 596). b. Comparettia coccinea (Vieira 156). c. Coppensia blanchetii (Vieira 249). d. Encyclia patens (Vieira 213). e. Epidendrum campestre (Vieira 139). f. Epidendrum cf. chlorinum (Vieira 147). g. Epidendrum dendrobioides (Fernandes et al. 673). h. Epidendrum proligerum (Vieira 152). i. Epidendrum saxatile (Vieira 181). j. Epidendrum secundum (Vieira 214). k. Epistephium sclerophyllum (Caiafa \& Meireles 102). 1. Eurystyles actinosophila (Vieira 265).

Figure 5 - Dissected perianths. a. Cleistes tenuis (de Paula et al. 596). b. Comparettia coccinea (Vieira 156). c. Coppensia blanchetii (Vieira 249). d. Encyclia patens (Vieira 213). e. Epidendrum campestre (Vieira 139). f. Epidendrum cf. chlorinum (Vieira 147). g. Epidendrum dendrobioides (Fernandes et al. 673). h. Epidendrum proligerum (Vieira 152). i. Epidendrum saxatile (Vieira 181). j. Epidendrum secundum (Vieira 214). k. Epistephium sclerophyllum (Caiafa \& Meireles 102). 1. Eurystyles actinosophila (Vieira 265). 
ápice obtuso; pétalas espatuladas, unguiculadas, 7 $\times$ 4-4,5 mm, ápice obtuso a arredondado; labelo trilobado, âmbito oblato a largo-obovado, 1,2-1,4 $\times 1,3 \mathrm{~cm}$; calosidade verrucosa na base do labelo; lobos laterais suborbiculares, 2-3 × 2-3 mm, ápice arredondado, margem inteira; lobo mediano bilobado, unguiculado, lobos transversalmente elípticos, 6×8-9 mm, ápice arredondado, margem levemente ondulada. Ginostêmio 3-4 mm compr; antera apical, incumbente, versátil; grãos de pólen aglutinados em polínias. Polínias 2, maciças, providas de estipe e viscídio. Ovário + pedicelo 1,2-1,4 cm compr. Fruto não visto.

Material examinado: Sine loco, 13.IX.2013, fl., T.L. Vieira et al. 140 (SP, BHCB); 30.I.2015, fl., T.L. Vieira 249 (SP).

Coppensia blanchetii possui distribuição conhecida para a Bolívia e o Brasil, onde é comumente encontrada nos campos rupestres da Bahia e Minas Gerais, mas também é conhecida para os demais estados da Região Sudeste, além de Mato Grosso do Sul, Paraná, Pernambuco e Santa Catarina (BFG 2015; Tropicos 2015). Na SOB foi encontrada como terrícola ou saxícola em campo rupestre e borda de capão de mata. Floresce entre setembro e janeiro. Coppensia blanchetii se aproxima morfologicamente de $B$. gravesianum. Ambas as espécies pertenciam anteriormente a Oncidium s.l., logo, apresentam inflorescências laterais, flores com coloração variando entre o castanho e o amarelo, sépalas laterais coalescentes em maior ou menor extensão, pétalas geralmente unguiculadas e calosidade complexa, verrucosa a digitiforme, no disco do labelo.

Entretanto, ocorrem sobre diferentes substratos, uma vez que $C$. blanchetii é terrícola ou saxícola em campos rupestres, predominantemente, enquanto $B$. gravesianum é epífita em matas de galeria. Além disso, como caraterísticas úteis na distinção entre as espécies, pode-se destacar: as folhas, que em $C$. blanchetii são lineares (vs. elípticas a oblanceoladas em B. gravesianum), além das flores menores (sépala dorsal ca. $6 \mathrm{~mm}$ vs. 20-22 mm compr.) e predomínio da cor amarela (vs. castanho).

\section{Encyclia Hook.}

12.1. Encyclia patens Hook., Bot. Mag. 57: t. 3013. 1830 .

Fig. $5 d$

Epífita, 33-36 cm alt. Crescimento simpodial. Raízes filiformes, cobertas por velame. Rizoma curto. Caule intumescido em pseudobulbo. Pseudobulbo heteroblástico, globoso a ovoide,
3-6 cm compr., 2-3-foliado. Folhas no ápice do pseudobulbo, alternas, suberetas, coriáceas, verdes, oblongas, $15-28,5 \times 1,2-1,5 \mathrm{~cm}$, sésseis, ápice obtuso a arredondado. Inflorescência terminal, em racemo ou panícula, laxa, 9-14-flora; pedúnculo 5-13 cm compr., brácteas do pedúnculo amplectivas, eretas, deltoides, 3-8 × 4-8 mm, ápice obtuso; raque 14,5-18 cm compr., brácteas florais deltoides, 2-4 × 3-7 mm, ápice obtuso. Flores ressupinadas, pediceladas, ecalcaradas; sépala dorsal completamente esverdeada ou maculada de vináceo, oblongo-elíptica a elíptica, $1,2-1,7 \times 0,4-0,5 \mathrm{~cm}$, ápice obtuso; sépalas laterais completamente esverdeadas ou maculadas de vináceo, elípticas, $1,4-1,7 \times 0,5-0,6 \mathrm{~cm}$, ápice obtuso; pétalas esverdeadas maculadas de vináceo, espatuladas, 1,2-1,6 × 0,6-0,7 cm, ápice obtuso; labelo alvo ou esverdeado, eventualmente com três pequenas máculas vináceas no lobo mediano, trilobado, livre, âmbito depressamente largoovado, 1,1-1,3 × 1,6 cm, calo bífido de coloração alva na base do lobo mediano; lobos laterais envolvendo o ginostêmio, oblongo-espatulados, ca. $8 \times 3 \mathrm{~mm}$, ápice arredondado, margem inteira; lobo mediano unguiculado, suborbicular, 7-9 × 8-9 $\mathrm{mm}$, margem levemente ondulada, ápice obtuso. Ginostêmio ca. 8 mm compr.; antera(s) apical(is), incumbente(s), 1 ou 3; grãos de pólen aglutinados em polínias. Polínias 4 por antera, maciças, lateralmente achatadas, providas de caudícula. Ovário + pedicelo 2-2,7 cm compr. Fruto não visto. Material examinado: Sine loco, 6.XII.2013, fl. cult. 1.X.2014, T.L. Vieira 257 (SP); 26.VI.2014, fl. cult. 16.VIII.2014, T.L. Vieira 213 (SP).

Encyclia patens é endêmica do Brasil, com distribuição conhecida para os estados de Alagoas, Bahia, Pernambuco, Sergipe e das regiões Sudeste e Sul (BFG 2015). Na SOB foi encontrada em capão de mata, associada a afloramentos rochosos e circundado por campo limpo e campo rupestre, na parte alta da serra. Floresce entre agosto e outubro. Pode ser reconhecida pela inflorescência terminal, em panícula, cujas flores apresentam labelo trilobado, com lobos laterais oblongoespatulados, envolvendo o ginostêmio, e de ápice arredondado. $\mathrm{Na}$ população em que foram coletados os espécimes para herborização, ocorrem duas variedades da espécie: E. patens Hook. var. patens (T.L. Vieira 213) e E. patens Hook. var. serroniana (Barb.Rodr.) Romanini \& F.Barros (T.L. Vieira 257), as quais podem ser diferenciadas, basicamente, pelo número de anteras, sendo uma e três, respectivamente. 


\section{Epidendrum L.}

Ervas epífitas, paludícolas, rupícolas ou saxícolas. Crescimento simpodial. Raízes filiformes, cobertas por velame. Rizoma geralmente curto. Cauloma normalmente não intumescido

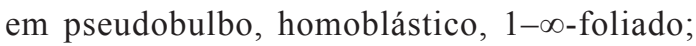
pseudobulbos, quando presentes, obclavados a ovoides. Folhas alternas, dísticas, verdes a vináceas, base amplexicaule. Inflorescência geralmente

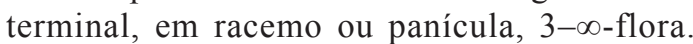
Flores pediceladas ou sésseis, ressupinadas ou não, ecalcaradas, verdes, amareladas, róseas ou lilases, membranáceas; sépalas livres entre si, de tamanho semelhante, formas variadas, as laterais geralmente falcadas; pétalas livres, oblanceoladas, geralmente mais estreitas que as sépalas; labelo inteiro ou trilobado, calo de forma e coloração variadas, lobos de formas variadas, base em unguículo adnato às margens do ginostêmio por toda a extensão deste. Ginostêmio cilíndrico a claviforme; antera apical, incumbente, versátil; grãos de pólen aglutinados em polínias. Polínias 4, maciças, providas apenas de caudículas. Zona de abscisão entre pedicelo e ovário ausente. Fruto cápsula.

\section{Chave de identificação para espécies de Epidendrum ocorrentes na Serra do Ouro Branco}

1. Raque da inflorescência $<5 \mathrm{~mm}$ compr.

2. Plantas de crescimento simpodial ortogonal em relação ao substrato, com caulomas emergindo sucessivamente a partir dos entrenós; labelo sutilmente convexo ....... 4. Epidendrum proligerum

2'. Plantas de crescimento simpodial paralelo em relação ao substrato, com caulomas emergindo a partir do rizoma; labelo conduplicado

2. Epidendrum cf. chlorinum

1'. Raque da inflorescência $\geq 3,5 \mathrm{~cm}$ compr.

3. Flores ressupinadas.

4. Cauloma com base intumescida em pseudobulbo obclavado; inflorescência multiflora; pétalas oblanceoladas; lobos laterais do labelo subreniformes 1. Epidendrum campestre

4'. Cauloma não intumescido em pseudobulbo; inflorescência pauciflora; pétalas lineares; lobos laterais do labelo espatulados. 5. Epidendrum saxatile

3'. Flores não ressupinadas.

5. Flores róseas ou lilases; labelo trilobado, plano, com margens dos lobos fimbriadas. 6. Epidendrum secundum

5'. Flores amarelo-esverdeadas; labelo inteiro, conduplicado, com margens inteiras

3. Epidendrum dendrobioides

13.1. Epidendrum campestre Lindl., Edward's Bot. Reg. 30(Misc.): 17. $1844 . \quad$ Fig. 5e Rupícola ou saxícola, 23-60 cm alt. Crescimento simpodial paralelo em relação ao substrato, com caulomas emergindo a partir do rizoma; cauloma com base intumescida em pseudobulbo. Pseudobulbo ovoide a obclavado, 4-6 cm compr., porção foliosa do cauloma 4-7-foliada. Folhas subpatentes, coriáceas, verdes, elípticas, 4-8,5 × 0,7-1,7 cm, ápice agudo. Inflorescência em racemo ou panícula, laxa, multiflora; pedúnculo 9,5-27 cm compr.; brácteas do pedúnculo amplectivas, eretas, lanceoladas, $1,5-5 \times 0,2-0,8 \mathrm{~cm}$, ápice agudo; raque $4-17,5 \mathrm{~cm}$ compr.; brácteas florais triangulares a linear-triangulares, $0,2-1,8 \times 0,1$ $0,3 \mathrm{~cm}$, ápice agudo a aristado. Flores róseas ou lilases, ressupinadas, pediceladas; sépala dorsal oblanceolada a elíptica, $8-10 \times 3 \mathrm{~mm}$, ápice agudo; sépalas laterais elíptico-falcadas, 9-10
× 3-4 mm, ápice agudo; pétalas oblanceoladas, 8-10 × 2,5-3 mm, ápice obtuso; labelo trilobado a subtrilobado, plano, âmbito depressamente obovado a transversalmente elíptico, 8-9 × 11$12 \mathrm{~mm}$, calosidade alva formada por três lamelas longitudinais, na base do labelo; lobos laterais sub-reniformes, 5 × 5-6 mm, ápice arredondado, margem levemente ondulada; lobo mediano reniforme, 2-3 × 6-7 mm, ápice emarginado, margem levemente ondulada. Ginostêmio 5-6 mm compr. Ovário + pedicelo 1,1-1,7 cm compr. Fruto fusiforme, $1,3 \times 0,6 \mathrm{~cm}$.

Material examinado: Sine loco, 24.VII.1987, fl., D.C. Zappi et al. (SPF); 27.VI.2001, fl. e fr., A.N. Caiafa 181 (VIC); Área 2, 4.VIII.2002, fl., C.C. de Paula et al. 210 (VIC); Área 1, 8.VI.2002, fl., C.C. de Paula et al. 25 (VIC); Campo rupestre próximo às antenas, 13.IX.2013, fl., T.L. Vieira et al. 139 (SP, BHCB); 24.VI.2014, fl., T.L. Vieira 199 (SP).

Epidendrum campestre é endêmica do Brasil, com distribuição conhecida para os estados do 
Espírito Santo, Goiás, Mato Grosso, Mato Grosso do Sul, Minas Gerais e São Paulo (BFG 2015). Na SOB é comumente encontrada em afloramentos rochosos no campo rupestre. Floresce de junho a setembro. Dentre as espécies do gênero encontradas na $\mathrm{SOB}$, pode ser reconhecida pelas flores róseas ou lilases, ressupinadas, em conjunto com a morfologia do cauloma, intumescido na base, com coloração avermelhada.

13.2. Epidendrum cf. chlorinum Barb.Rodr., Gen. Sp. Orchid. 2: 139. 1881.

Fig. $5 \mathrm{f}$

Epífita, 39-78 cm alt. Crescimento simpodial paralelo em relação ao substrato, com caulomas emergindo a partir do rizoma; cauloma não intumescido em pseudobulbo, coberto por bainhas escariosas, 4-foliado no ápice. Folhas subpatentes, coriáceas, verdes, estreito-elípticas, 3-15,5 × 0,5$1,5 \mathrm{~cm}$, ápice agudo a apiculado. Inflorescência em racemo, congesta, ca. 4-flora; pedúnculo 1,5-3 cm compr.; brácteas do pedúnculo triangulares, 1-1,5 $\times 0,3-0,4 \mathrm{~cm}$, ápice agudo; raque ca. $4 \mathrm{~mm}$ compr., brácteas florais triangulares, 3-11 × 1-3 mm, ápice agudo. Flores verde-amareladas, ressupinadas, pediceladas; sépala dorsal oblongo-lanceolada, 10 $\times 2,5 \mathrm{~mm}$, ápice agudo; sépalas laterais elípticas, levemente falcadas, 8-9 × 3-4 mm, ápice agudo; pétalas estreitamente oblanceoladas a elípticas, ocasionalmente levemente falcadas, 9-10 × 1,5-3 $\mathrm{mm}$, ápice obtuso; labelo inteiro, conduplicado, sub-reniforme a sub-romboide, ca. $5 \times 10 \mathrm{~mm}$, margem inteira, ápice acuminado, calosidade formada por três pequenas lamelas longitudinais, na base do labelo. Ginostêmio 5-6 mm compr. Ovário + pedicelo $8-9 \mathrm{~mm}$ compr. Fruto fusiforme, 2-2,5 $\times 1-1,8 \mathrm{~cm}$.

Material examinado: Sine loco, 12.V.1990, fr., M.M. Arbo et al. 3968 (SPF); 14.IX.2013, fl. cult. II.2014, T.L. Vieira et al. 147 (SP).

Epidendrum chlorinum é endêmica do Brasil, com distribuição conhecida para os estados da Bahia e da Região Sudeste (BFG 2015). Na SOB ocorre em mata de galeria. Floresceu em cultivo em fevereiro. O espécime mantido em cultivo apresentou floração anômala, comprometendo a análise morfológica das flores, enquanto o outro material analisado (M.M. Arbo et al. 3968) foi coletado apenas com frutos. A morfologia vegetativa, a coloração esverdeada das flores e a forma do labelo remetem a E. chlorinum, entretanto, diante da falta material completo que permitisse a identificação com maior certeza, optamos por tratar os materiais examinados como E. cf. chlorinum.
13.3. Epidendrum dendrobioides Thunb., $\mathrm{Pl}$. Bras. 2: 17.1818.

Fig. $5 \mathrm{~g}$

Paludícola, $22-33 \mathrm{~cm}$ alt. Crescimento simpodial paralelo em relação ao substrato, com caulomas emergindo a partir do rizoma e, eventualmente, a partir de entrenós do cauloma; cauloma não intumescido em pseudobulbo, multifoliado. Folhas suberetas, coriáceas, verdeclaras, lanceoladas, $2-7,1 \times 0,4-0,8 \mathrm{~cm}$, ápice apiculado a mucronado. Inflorescência em racemo ou panícula, laxa, multiflora; pedúnculo inconspícuo a curto $(0,4-1 \mathrm{~cm}$ compr.); brácteas do pedúnculo, quando presentes, amplectivas, deltoides, 2-4 × 3-4 mm, ápice agudo; raque 6-11,5 cm compr.; brácteas florais ovadas a deltoides, patentes, 2-6 × 2-3 mm, ápice agudo. Flores verde-amareladas, não ressupinadas, sésseis; sépala dorsal elíptica, 6-7 × 2,5 mm, ápice obtuso; sépalas laterais elíptico-falcadas, ca. $6 \times 3 \mathrm{~mm}$, ápice obtuso; pétalas lineares, 5-6 61 $\mathrm{mm}$, ápice obtuso; labelo inteiro, conduplicado, transversalmente elíptico, ca. $4 \times 6,5 \mathrm{~mm}$, ápice acuminado, margem inteira, calosidade formada por duas pequenas protuberâncias, na base do labelo. Ginostêmio 3-4 mm compr. Ovário 8-9 $\mathrm{mm}$ compr. Fruto fusiforme, $9 \times 6-7 \mathrm{~mm}$.

Material examinado: Área 2, 2.II.2003, fl. e fr., C.C. de Paula et al. 666 (VIC); RPPN Gerdau AçoMinas, margem de córrego, 23.II.2008, fl. e fr., J.M. Fernandes et al. 673 (VIC).

Epidendrum dendrobioides ocorre na Venezuela e no Brasil, onde é conhecida para os estados da Bahia, Goiás, Mato Grosso, Mato Grosso do Sul, Paraná, Tocantins, e da Região Sudeste, além do Distrito Federal (BFG 2015). Na SOB foi encontrada como paludícola nas matas de galeria e córregos que cortam as formações campestres. Floresce no mês de fevereiro. Pode ser reconhecida pelo hábito paludícola, ocorrendo muitas vezes em leitos de córregos. Além disso, as flores são amareladas, carnosas, não ressupinadas e com labelo notavelmente conduplicado.

13.4. Epidendrum proligerum Barb.Rodr., Gen. Sp. Orchid. 1: 61. $1877 . \quad$ Fig. 5h

Epífita, 6-11 cm alt. Crescimento simpodial ortogonal em relação ao substrato, com caulomas emergindo sucessivamente a partir dos entrenós; cauloma não intumescido em pseudobulbo, 2-3-foliado no ápice. Folhas subpatentes, coriáceas, verdes, elípticas, 0,4-1,9 × 0,4-0,8 cm, ápice agudo. Inflorescência em racemo, congesta, ca. 3-flora; pedúnculo ca. $7 \mathrm{~mm}$ compr.; brácteas do pedúnculo ausentes; raque ca. $3 \mathrm{~mm}$ compr.; 
brácteas florais linear-triangulares, 4-5 × 1-1,5 $\mathrm{mm}$, ápice agudo. Flores verde-amareladas, ressupinadas, pediceldas; sépala dorsal elíptica, ca. $10 \times 4 \mathrm{~mm}$, ápice obtuso; sépalas laterais elíptico-falcadas, ca. $10 \times 4 \mathrm{~mm}$, ápice agudo; pétalas estreitamente oblanceoladas, ca. $10 \times 1$ $\mathrm{mm}$, ápice obtuso; labelo subtrilobado, convexo, âmbito reniforme, $8 \times 11-12 \mathrm{~mm}$, calosidade formada por duas pequenas protuberâncias, na base do labelo; lobos laterais depressamente ovados, ca. 4-5 × 5-6 mm, ápice arredondado, margem denteada próximo ao lobo mediano; lobo mediano semi-elíptico, ca. $2 \times 6 \mathrm{~mm}$, ápice emarginado a arredondado, margem inteira. Ginostêmio 6-8 mm compr. Ovário + pedicelo $1,2-1,6 \mathrm{~cm}$ compr. Fruto não visto.

Material examinado: Sine loco, 14.IX.2013, fl. cult. 24.IV.2014, T.L. Vieira et al. 152 (SP).

Epidendrum proligerum é endêmica do Brasil, com distribuição conhecida para os estados de Alagoas, Bahia, Pernambuco e das regiões Sudeste e Sul (BFG 2015). Na SOB foi encontrada em mata de galeria. Floresceu em cultivo em maio. Pode ser diferencia das demais espécies do gênero para a SOB pelo hábito epifítico, associado ao pequeno tamanho da planta (até $11 \mathrm{~cm}$ alt.), com formação de brotações laterais e flores esverdeadas.

13.5. Epidendrum saxatile Lindl., J. Bot. (Hooker) 3: 84. $1841 . \quad$ Fig. 5i Epífita, 30-42 cm alt. Crescimento simpodial ortogonal em relação ao substrato, com caulomas emergindo sucessivamente a partir dos entrenós; cauloma não intumescido em pseudobulbo, 1-4-foliado no ápice. Folhas suberetas, coriáceas, verdes, elípticas a lanceoladas, $2,5-7 \times 0,3-0,6 \mathrm{~cm}$, ápice agudo a apiculado. Inflorescência em racemo ou panícula, laxa, pauciflora; pedúnculo 8,5-13 cm compr.; brácteas do pedúnculo amplectivas, eretas, lanceoladas, $0,7-2,7 \times 0,2-0,4 \mathrm{~cm}$, ápice agudo; raque 4,5-14 cm compr.; brácteas florais triangulares, 1-5 × 1-2 mm, ápice agudo. Flores róseo-lilases a lilases, ressupinadas, pediceladas; sépala dorsal elíptica, 7,5-10 × 3-4 mm, ápice obtuso; sépalas laterais elíptico-falcadas, 7-9 $\times$ 3-4,5 mm, ápice acuminado; pétalas lineares, 8-9 $\times 1 \mathrm{~mm}$, ápice obtuso; labelo trilobado, plano, âmbito depressamente ovado a reniforme, 8-11× $12-17 \mathrm{~mm}$, calosidade de coloração alva formada por duas pequenas protuberâncias, na base do labelo; lobos laterais espatulados, 5-8 5 5-8 mm, ápice arredondado, margem levemente sinuosa a erosa; lobo mediano unguiculado, istmo ca. 2,5 mm compr., porção apical reniforme, ca. 3,5 × $7,5 \mathrm{~mm}$, ápice emarginado, margem fimbriada. Ginostêmio ca. $5 \mathrm{~mm}$ compr. Ovário + pedicelo $1,2-1,5 \mathrm{~cm}$ compr. Fruto fusiforme, 1,3-1,5 $\times$ $1-1,2 \mathrm{~cm}$.

Material examinado: Sine loco, 18.IV.1957, fl., E. Pereira \& G. Pabst 2976 (HB); 24.VII.1987, fl. e fr., R. Mello-Silva et al. CFCR 11224 (SPF); 12.V.1990, fl. e fr., M.M. Arbo et al. 3903 (SPF); Estrada para o Morro do Gabriel, 9.III.1995, fl., V.C. Souza et al. 8095 (ESA, SP); Área 3, 10.VI.2002, fl., C.C. de Paula et al. 96 (VIC); Sine loco, 28.IX.2012, fl., M. Sobral et al. 15000 (HUFSJ); porção leste da serra, à direita da rodovia MG-443, 17.III.2014, fl., T.L. Vieira 181 (SP, BHCB).

Epidendrum saxatile é conhecida para o Brasil, Guiana, Paraguai e Venezuela. No Brasil ocorre nos estados da Bahia, Ceará, Pernambuco e da Região Sudeste (BFG 2015). Na SOB é encontrada nos campos rupestres, como epífita sobre espécies de Vellozia. Floresce de dezembro a junho. Distingue-se das demais espécies do gênero na SOB pelo labelo marcadamente trilobado, com lobos laterais espatulados, e lobo mediano com margem fimbriada.

13.6. Epidendrum secundum Jacq., Enum. Syst. P1.: 29. 1760.

Fig. 5 j

Rupícola ou saxícola, 46-113 cm alt. Crescimento simpodial paralelo em relação ao substrato, com caulomas emergindo a partir do rizoma e, eventualmente, a partir de entrenós da inflorescência; cauloma não intumescido em pseudobulbo, multifoliado. Folhas patentes a subpatentes, coriáceas, verdes a vináceas, lanceoladas, ovado-lanceoladas ou elípticas, $3-11 \times 0,9-2,6 \mathrm{~cm}$, ápice agudo, obtuso ou emarginado, base amplexicaule. Inflorescência em racemo ou corimbo, subcongesta, geralmente multiflora; pedúnculo 13,5-53,5 cm compr.; brácteas do pedúnculo amplectivas, escariosas, adpressas ao caule, elípticas a lanceoladas, $1,5-8,7 \times 0,3-1 \mathrm{~cm}$, ápice obtuso a agudo; raque $3,5-13 \mathrm{~cm}$ compr.; brácteas florais triangulares, 2-7 $\times 1-3 \mathrm{~mm}$, ápice agudo. Flores róseas a lilases, não ressupinadas, pediceladas; sépala dorsal oblonga a elíptica, 6-8 × 2-4 mm, ápice agudo a acuminado; sépalas laterais elípticofalcadas, 7-10 × 3-4 mm, ápice acuminado; pétalas elípticas, 7-9 × 2-3,5 mm, ápice agudo; labelo trilobado, plano; calosidade amarela na base, tornando-se alva em direção ao lobos do 
labelo, bífida, posicionada na base do labelo; lobos laterais suborbiculares, 2-3 × 3-4 mm, recortado, margem recortada; lobo mediano inteiro ou bilobado, âmbito depressamente obovado, 2-3 × 3,5-6 mm, ápice acuminado ou emarginado, margem fimbriada. Ginostêmio ca. $4 \mathrm{~mm}$ compr. Ovário + pedicelo 1,2-2,5 cm compr. Fruto não visto.

Material examinado: Área 2, 21.I.2003, fl., C.C. de Paula et al. 614 (VIC); 6.IV.2013, fl., C.C. de Paula et al. 755 (VIC); Sine loco, 26.6.2014, fl., T.L. Vieira 214 (SP, BHCB).

Epidendrum secundum é uma espécie amplamente distribuída entre a América Central e a região tropical da América do Sul (BFG 2015; Govaerts 2015). Na SOB foi encontrada em campo rupestre, sobre canga. Floresce durante praticamente todo o ano. Pode ser reconhecida, dentre as espécies do gênero para a área de estudo, pelas inflorescências geralmente com pedúnculo longo, e a raque curta, com as flores dispostas de forma congesta. As flores são róseas ou lilases, não ressupinadas, com labelo trilobado e calosidade amarela na base.

\section{Epistephium Kunth}

14.1. Epistephium sclerophyllum Lindl., Gen. Sp. Orchid. P1.: 433. 1840.

Fig. $5 \mathrm{k}$

Terrícola, 37-55 cm alt. Crescimento simpodial. Raízes tuberiformes, não cobertas por velame. Rizoma inconspícuo. Caule não intumescido em pseudobulbo. Folhas alternas, espiraladas, suberetas, coriáceas, lanceoladas a largo-ovadas, 3,5-7,7 × 2-5,2 cm, sésseis, ápice agudo a acuminado, venação reticulada. Inflorescência terminal, em racemo, laxa, pauciflora; pedúnculo 6,5-12 cm compr.; raque $12-27 \mathrm{~cm}$ compr.; brácteas lanceoladas a deltoides, 0,6-3 × 0,4-0,6 cm, ápice agudo a obtuso. Flores lilases, muito membranáceas, ressupinadas, pediceladas, ecalcaradas, calículo presente, zona de abscisão situada entre perianto e ovário; sépala dorsal estreito-oblanceolada, 3,3-4 × 0,5 cm, ápice agudo; sépalas laterais estreito-oblanceoladas a oblanceoladas, levemente falcadas, 3,3-4 × 0,5-0,7 cm, ápice agudo; pétalas livres, oblanceoladas, 3,2-4 × 0,7-1,1 cm, ápice agudo; labelo inteiro, unguiculado, adnato ao ginostêmio na porção do unguículo, âmbito ovado a largo-ovado não incluindo o unguículo, 2,6-3,2 × 2,1-2,8 $\mathrm{cm}$, ápice emarginado, glândulas nectaríferas ausentes na base, margem ondulada, disco com crista central fimbriada. Ginostêmio 2,8-3 cm compr.; antera apical, incumbente, versátil; grãos de pólen livres, em mônades, não formando polínias verdadeiras. Pedicelo + ovário 2,5-3 cm compr.; zona de abscisão entre pedicelo e ovário ausente. Fruto cilíndrico, ca. $4 \times 0,5 \mathrm{~cm}$. Material examinado: Sine loco, 1.III.2001, fl. e fr., A.N. Caiafa \& L.D. Meireles 102 (VIC); Área 2, 4.II.2003, fl., C.C de Paula et al. 668 (VIC).

Epistephium sclerophyllum distribui-se desde o norte da América do Sul até o nordeste da Argentina (Govaerts et al. 2015), no Brasil possui registros para os estados do Amazonas, Bahia, Minas Gerais, Pará, Paraná, São Paulo, Tocantins, e da Região Centro-Oeste, além do Distrito Federal (BFG 2015). Na SOB foi encontrada em campo limpo. Floresce em fevereiro e março. Pode ser facilmente reconhecida por apresentar folhas com venação reticulada, além das flores lilases, vistosas e muito membranáceas, com um calículo presente na base do perianto.

\section{Eurystyles Wawra}

15.1. Eurystyles actinosophila (Barb.Rodr.) Schltr., Repert. Spec. Nov. Regni Veg. Beih. 35: 39. 1925.

Fig. 51

Epífita, ca. 3,5 cm alt. Crescimento simpodial. Raízes tuberiformes. Rizoma inconspícuo. Caule não intumescido em pseudobulbo. Folhas rosuladas, subpatentes a suberetas, membranáceas, verdes, elípticas a estreito-elípticas, 1,7-2,6 × 0,7-0,9 cm, base atenuada, ápice agudo a acuminado, margem ciliada. Inflorescência terminal, em espiga, congesta, pilosa, ca. 6-flora; pedúnculo 1,5-2,3 cm compr.; brácteas do pedúnculo suberetas a subpatentes, as do ápice encurvadas, lanceoladas, 10-11 × 3-4 mm, ápice agudo; raque inconspícua; brácteas florais lanceoladas, 7-11 × 2,5-4 mm, ápice encurvado, acuminado. Flores alvas, externamente pubescentes, ressupinadas, sésseis, ecalcaradas; sépala dorsal lanceolada, coalescente na base às laterais formando um curto tubo sepalino, 4-5 × 1,5 $\mathrm{mm}$, ápice agudo; sépalas laterais adnatas ao pé da coluna, coalescentes e infladas na base, formando pequeno mento, lanceoladas, levemente falcadas, ca. $7 \times 1,5 \mathrm{~mm}$, ápice agudo; pétalas aderidas à sépala dorsal, lanceoladas, falcadas, ca. 3,5 $\times 1 \mathrm{~mm}$, ápice agudo; labelo unguiculado, dividido em hipoquílio e epiquílio, âmbito oblongo-lanceolado, ca. $5 \times 3 \mathrm{~mm}$, par de glândulas nectaríferas localizadas em aurículas 
na base do labelo, ápice arredondado, margem inteira; hipoquílio oblongo, ca. $3,5 \times 3 \mathrm{~mm}$, margens inteiras, aderidas ao ginostêmio, com uma constrição na porção mediana; epiquílio suborbicular, ca. $1,5 \times 1 \mathrm{~mm}$, ápice arredondado, margem inteira. Ginostêmio ca. $3 \mathrm{~mm}$ compr. base projetada em pé de 1,2-1,5 mm compr.; rostelo membranáceo; antera dorsal, ereta; grãos de pólen aglutinados em polínias. Polínias 2, farinosas, providas apenas de viscídio. Ovário 3,5-4 mm compr., glabro. Fruto não visto.

Material examinado: Sine loco, 5.XII.2013, fl. cult. 21.IV.2014, T.L. Vieira 167 (SP); 5.XII.2013, fl. cult. IV.2015, T.L. Vieira 265 (SP).

Eurystyles actinosophila distribui-se pelo Brasil, Paraguai e também no norte da Argentina (Govaerts et al. 2015). No Brasil, ocorre quase que exclusivamente no domínio Atlântico, com registros para os estados da Bahia e das regiões Sudeste e Sul (Barros et al. 2015). Na SOB foi coletada em Floresta Estacional Semidecidual e mata de galeria. Floresce em abril. Pode ser reconhecida pelo porte reduzido (ca. $3,5 \mathrm{~cm}$ alt.), estruturas foliares membranáceas, sendo a única espécie epífita da subtribo Spiranthinae na SOB. A inflorescência é pendente, muito congesta, com brácteas bem desenvolvidas em relação ao tamanho das flores.

\section{Galeandra Lindl.}

16.1. Galeandra montana Barb.Rodr., Revista Engen. 3(4): 73. 1881.

Fig. 6a

Terrícola, 43-48 $\mathrm{cm}$ alt. incluindo a inflorescência. Crescimento simpodial. Raízes filiformes, cobertas por velame. Rizoma inconspícuo. Cauloma intumescido em pseudobulbo. Pseudobulbo homoblástico, ovoide, 4-4,5 cm compr., 5-6-foliado. Folhas alternas, dísticas, suberetas, conduplicadas, cartáceas, verdes, linear-lanceoladas, 15-32 $\times$ $0,8-1,2 \mathrm{~cm}$, base em bainha amplexicaule, ápice agudo. Inflorescência terminal, em racemo, laxa, ca. 2-flora; pedúnculo 35-38 cm compr.; brácteas do pedúnculo amplectivas, escariosas, eretas, linear-lanceoladas a lanceoladas, 5,5-19 $\times$ $0,4-0,6 \mathrm{~cm}$, ápice agudo; raque ca. $2 \mathrm{~cm}$ compr.; brácteas florais lanceoladas, 1,6-3,6 × 0,3-0,4 $\mathrm{cm}$, ápice agudo. Flores variando entre tons de amarelo e vináceo, ressupinadas, pediceladas, calcaradas; calcar formado pela base do labelo, do tipo esporão; sépala dorsal oblanceolada, ca. $3 \times 0,7 \mathrm{~cm}$, ápice agudo; sépalas laterais livres, oblanceoladas, falcadas, ca. $3 \times 0,6 \mathrm{~cm}$, ápice agudo; pétalas oblanceoladas, falcadas, ca. 2,7 $\times 0,8 \mathrm{~cm}$, ápice agudo; labelo trilobado, infundibuliforme, ca. 4,5 × 3,6 cm, com base formando esporão; calosidade formada por três lamelas longitudinais, da base até cerca de $1 / 2 \mathrm{da}$ extensão do labelo; lobos laterais obovados, ca. $4 \times 1,4 \mathrm{~cm}$, ápice arredondado, margem inteira; lobo mediano oblato, ca. $1,1 \times 1,5 \mathrm{~cm}$, ápice truncado, margem ondulada. Ginostêmio ca. 1,2 cm compr.; antera apical, incumbente, versátil; grãos de pólen aglutinados em polínias. Polínias 2 , maciças, providas de estipe e viscídio. Ovário + pedicelo ca. $3 \mathrm{~cm}$ compr. Fruto não visto.

Material examinado: porção da serra a oeste das antenas, 28.I.2015, fl., T.L. Vieira 233 (SP, BHCB).

Galeandra montana é endêmica do Brasil, ocorrendo nos estados da Bahia, Maranhão, Minas Gerais, Pará, Rio Grande do Norte, Rondônia, São Paulo, Sergipe, Tocantins, e da Região Centro-Oeste além do Distrito Federal (BFG 2015). Na SOB foi encontrada como terrícola, em locais com acúmulo de solo entre rochas no campo rupestre. Floresce em janeiro. Pode ser facilmente diferenciada das demais espécies da SOB pelo labelo infundibuliforme com a base projetada formando um calcar.

\section{Habenaria Willd.}

Ervas terrícolas. Raízes filiformes; tuberoides geralmente presentes. Rizoma subterrâneo, inconspícuo. Caule aéreo ereto, não intumescido em pseudobulbo, produzido apenas no período reprodutivo, desaparecendo após a deiscência dos frutos. Folhas alternas, espiraladas, amplexicaules, geralmente verdes, variando entre tons mais claros ou escuros. Inflorescência terminal, em racemo, pauci a multiflora. Flores pediceladas, ressupinadas, calcaradas, verdes a alvas, menos comumente amarelas ou amarelo-esverdeadas; sépalas livres, a dorsal se apresenta, juntamente com as pétalas, na forma de um capuz, as laterais patentes ou reflexas e/ou torcidas; pétalas inteiras a bipartidas; labelo inteiro ou tripartido, geralmente provido de um calcar na base, reduzido ou extremamente longo. Ginostêmio curto a alongado; antera fundida ao ginostêmio, os lóculos são adjacentes ou separados, ligados por um conectivo em forma de "U"; grãos de pólen aglutinados em polínias. Polínias 2, sécteis, providas de caudícula e viscídio; estigma bilobado, lobos claviformes longos ou curtos. Zona de abscisão entre pedicelo e ovário ausente. 

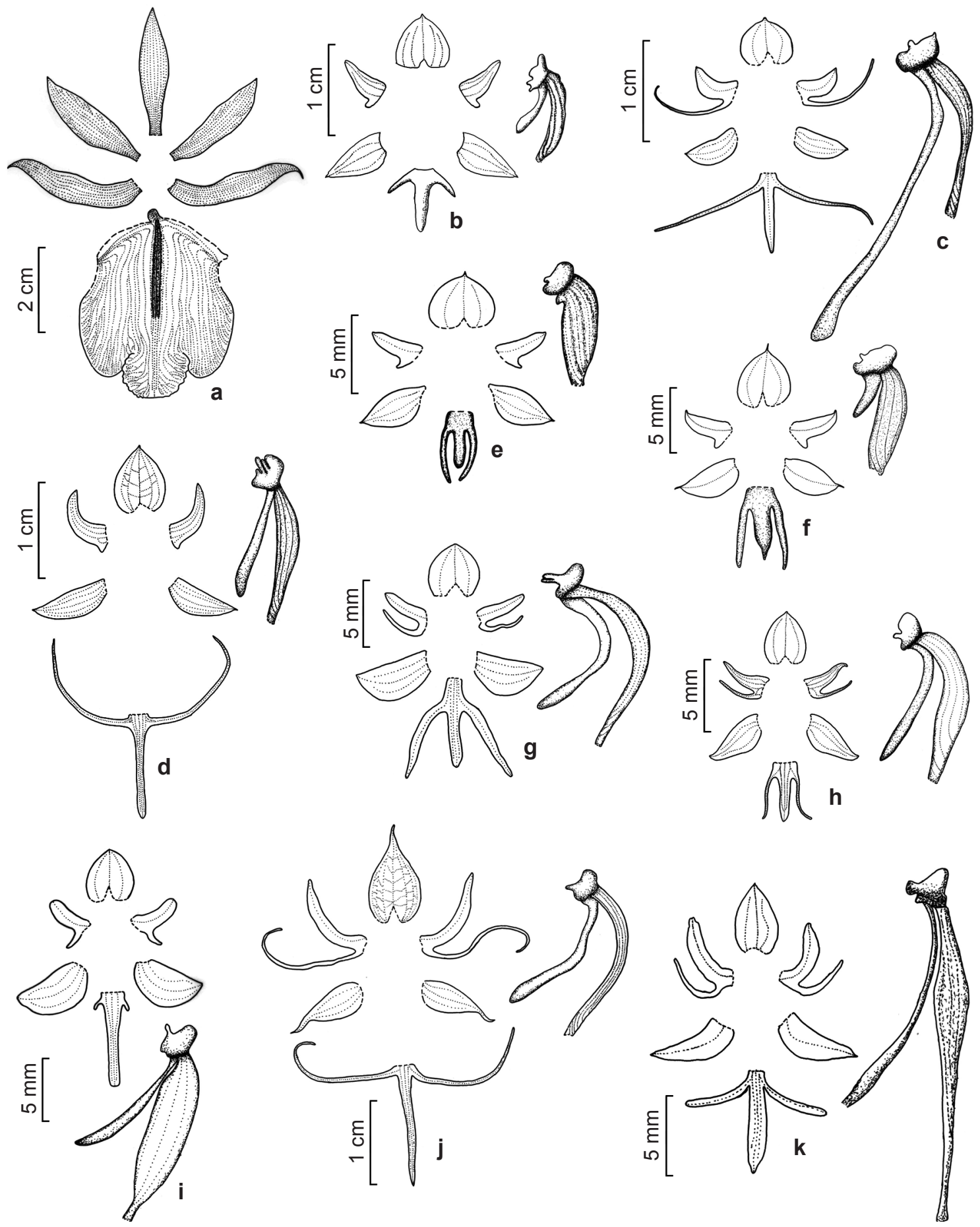

Figura 6 - Periantos dissecados. a. Galeandra montana (Vieira 233). b. Habenaria brevidens (Batista 2616). c. Habenaria caldensis (Vieira 171). d. Habenaria crucifera (Batista 2607). e. Habenaria guilleminii (Batista 2613). f. Habenaria aff. guilleminii (Souza et al. 7907). g. Habenaria humilis (Batista 2619). h. Habenaria imbricate (Batista 2623). i. Habenaria josephensis (Vieira 155). j. Habenaria lavrensis (Vieira 180). k. Habenaria melanopoda (Batista 2612).

Figure 6 - Dissected perianths. . Galeandra montana (Vieira 233). b. Habenaria brevidens (Batista 2616). c. Habenaria caldensis (Vieira 171). d. Habenaria crucifera (Batista 2607). e. Habenaria guilleminii (Batista 2613). f. Habenaria aff. guilleminii (Souza et al. 7907). g. Habenaria humilis (Batista 2619). h. Habenaria imbricate (Batista 2623). i. Habenaria josephensis (Vieira 155). j. Habenaria lavrensis (Vieira 180). k. Habenaria melanopoda (Batista 2612). 
Chave de identificação para espécies de Habenaria ocorrentes na Serra do Ouro Branco

1. Labelo inteiro ou com os segmentos laterais reduzidos a dentículos.

2. Pétalas inteiras, espatuladas, ápice arredondado a subtruncado

14. Habenaria petalodes

2'. Pétalas bipartidas ou com dois dentículos laterais, segmento anterior 1-2 mm compr., segmento posterior oblongo a oblongo-laceolado, falcado, ápice obtuso.

3. Labelo inteiro, $12-13 \times 2-3 \mathrm{~mm}$; calcar 3-3,3 cm compr. 13. Habenaria obtusa

3'. Labelo com segmentos laterais reduzidos a dentículos (ca. $1 \mathrm{~mm}$ compr.), segmento mediano 6-8 × $1 \mathrm{~mm}$; calcar $0,9-1,2 \mathrm{~cm}$ compr.

8. Habenaria josephensis

1'. Labelo tripartido.

4. Pétalas inteiras ou com segmento anterior muito curto ou reduzido a um dentículo $\leq 2 \mathrm{~mm}$ compr.

5. Folhas linear-lanceoladas, eretas e firmemente adpressas ao caule em toda extensão deste; calcar 8-12 mm compr.

3. Habenaria crucifera

5'. Folhas variando entre ovado-lanceoladas, elíptico-lanceoladas e lanceoladas, suberetas na base do caule, tornando-se eretas em direção ao ápice deste; calcar até $7 \mathrm{~mm}$ compr.

6. Segmentos laterais do labelo mais curtos que o mediano; calcar 6-7 mm compr.......... 1. Habenaria brevidens

6'. Segmentos laterais do labelo mais longos que o mediano; calcar até $4 \mathrm{~mm}$ compr.

7. Calcar ca. $1 \mathrm{~mm}$ compr. 4. Habenaria guilleminii

7'. Calcar ca. $4 \mathrm{~mm}$ compr 5. Habenaria aff. guilleminii

4'. Pétalas bipartidas, segmento anterior $\geq 4 \mathrm{~mm}$ compr.

8. Segmentos laterais do labelo $\geq 1 \mathrm{~cm}$ compr.

9. Calcar maior em comprimento que ovário + pedicelo; sépala dorsal ca. $5 \mathrm{~mm}$ compr. .

2. Habenaria caldensis

9'. Calcar de comprimento menor ou igual a ovário + pedicelo; sépala dorsal 7-14 mm compr.

10. Inflorescência congesta; segmentos anteriores das pétalas com aproximadamente o mesmo comprimento (6-9 $\mathrm{mm}$ compr.) dos posteriores (6-7 $\mathrm{mm}$ compr.).

17. Habenaria subviridis

10'. Inflorescência subcongesta a laxa; segmentos anteriores das pétalas notavelmente mais longos (13-30 mm compr.) que os posteriores (8-16 mm compr.).

11. Plantas ca. $66 \mathrm{~cm}$ alt.; raque da inflorescência ca. $16 \mathrm{~cm}$ compr.; sépala dorsal ca. 1,4 $\times 1 \mathrm{~cm}$; segmento mediano do labelo ca. $2 \mathrm{~cm}$ compr..

11. Habenaria nasuta

11'. Plantas até $46,5 \mathrm{~cm}$ alt.; raque da inflorescência 3-8 cm compr.; sépala dorsal $1-1,1 \times 0,6-0,7 \mathrm{~cm}$; segmento mediano do labelo $0,8-1,3 \mathrm{~cm}$ compr.

12. Folhas lanceoladas, eretas, adpressas ao caule; flores verdes; calcar 9-10 mm compr.; ovário + pedicelo ca. 1,3 cm compr.

12. Habenaria nuda var. pygmaea

12'. Folhas lineares a linear-lanceoladas, suberetas; flores alvas; calcar 16-18 mm compr.; ovário + pedicelo 2-2,3 cm compr.

9. Habenaria lavrensis

8'. Segmentos laterais do labelo $\leq 8 \mathrm{~mm}$ compr.

13. Segmentos laterais do labelo mais curtos que o mediano; calcar ca. $15 \mathrm{~mm}$ compr........ 10. Habenaria melanopoda

13'. Segmentos laterais do labelo de mesmo comprimento ou mais longos que o mediano; calcar $\leq 12 \mathrm{~mm}$ compr.

14. Folhas linear-lanceoladas; calcar curvado; sépala dorsal com ápice obtuso.

15. Sépalas laterais elíptico-falcadas, ápice obtuso; segmentos posteriores das pétalas espatulados a estreito-oblongos, falcados, ápice obtuso.

6. Habenaria humilis

15'. Sépalas laterais lanceolado-falcadas, ápice apiculado; segmentos posteriores das pétalas lanceolado-falcados, ápice agudo .....16. Habenaria secundiflora 
14'. Folhas variando de ovado-lanceoladas, elíptico lanceoladas a lanceoladas; calcar ereto a subereto; sépala dorsal com ápice apiculado.

16. Inflorescência congesta, com brácteas bem desenvolvidas recobrindo a raque; labelo com segmentos laterais e mediano de 3-4 mm compr. 7. Habenaria imbricata

16'. Inflorescência laxa, raque visível, não recoberta pelas brácteas; labelo com segmentos laterais de 6-7 mm compr. e segmento mediano de 5-6 $\mathrm{mm}$ compr.

15. Habenaria cf. rupicola

17.1. Habenaria brevidens Lindl., Gen. Sp. Orchid. Pl.: 314. 1835.

Fig. $6 \mathrm{~b}$

Terrícola, 11,5-23,5 cm alt. Folhas da base suberetas e do ápice eretas, membranáceas, elíptico-lanceoladas a lanceoladas, $1,1-7 \times 0,5-1,6$ $\mathrm{cm}$, ápice apiculado. Inflorescência congesta; pedúnculo $0,8-2,5 \mathrm{~cm}$ compr., raque $2,5-14,5$ cm compr.; brácteas ovado-lanceoladas, $0,8-3,3$ $\times 0,6-1 \mathrm{~cm}$, ápice longamente acuminado. Flores amarelo-esverdeadas; sépala dorsal ovada, 6-7 $\times 5-6 \mathrm{~mm}$, ápice apiculado; sépalas laterais lanceoladas, levemente falcadas, 7-9 × 3-4 mm, ápice apiculado; pétalas bipartidas, segmento posterior lanceolado-falcado, 5-6 × 2-3 mm, ápice obtuso, segmento anterior curto ou reduzido a um dentículo, 1-2 mm compr., ápice obtuso; labelo tripartido, segmentos laterais estreito-oblongos, 2-4 mm compr., ápice obtuso, segmento mediano estreito-oblongo, 5-6 × 1-2 mm, ápice obtuso, calcar subereto, 6-7 mm compr.. Ginostêmio 2-3 $\mathrm{mm}$ compr. Ovário + pedicelo 1-1,5 cm compr. Fruto fusiforme, 9-11 × $4 \mathrm{~mm}$.

Material examinado: Sine loco, 18.IV.1957, fl. e fr., E. Pereira \& Pabst 3000 (RB), p.p.; estrada entre Ouro Branco e o Morro do Gabriel, ca. 9 km de Ouro Branco, 8.III.1995, fl., V.C. Souza et al. 7948 (ESA); 8.III.1995, fl., V.C. Souza et al. 7949 (ESA); Área 2, 28.II.2003, fl., C.C. de Paula et al. 699 (VIC); RPPN GERDAU, 23.II.2008, fl., J.M. Fernandes 681 (VIC); ca. de 10,6 km do entroncamento com a MG-443, no entorno do cume da serra, 5.III.2008, fl., J.A.N. Batista 2616 (BHCB).

Habenaria brevidens é endêmica do Brasil, com distribuição conhecida para os estados de Goiás, Minas Gerais e São Paulo, além do Distrito Federal (Batista et al. 2011a; BFG 2015). Na SOB foi encontrada em campo limpo. Floresce entre fevereiro e abril. Pode ser diferenciada das demais espécies do gênero na SOB pela coloração amarelada das flores, os segmentos anteriores das pétalas que são pouco desenvolvidos, às vezes reduzidos a dentículo, além dos segmentos laterais do labelo que são mais curtos que o mediano. Batista et al. (2011a) comentam que $H$. brevidens é muito similar a $H$. hydrophila Barb.Rodr. e que, possivelmente, estes sejam táxons coespecíficos.
17.2. Habenaria caldensis Kraenzl., Bot. Jahbr. Syst. 16: 128. 1892.

Fig. $6 \mathrm{c}$

Terrícola, 18-38 cm alt. Folhas da base suberetas e do ápice eretas, membranáceas, linearlanceoladas, 2,8-14 ×0,4-0,8 cm, ápice agudo. Inflorescência laxa; pedúnculo 2,2-4 cm compr., raque $4-7,5 \mathrm{~cm}$ compr.; brácteas lanceoladas a ovadas, $0,8-3 \times 0,4-0,9 \mathrm{~cm}$, ápice longamente acuminado. Flores alvas; sépala dorsal largoovada, $5 \times 4-6 \mathrm{~mm}$, ápice apiculado; sépalas laterais lanceolado-falcadas, 5-6 × $3 \mathrm{~mm}$, ápice apiculado; pétalas bipartidas, segmento posterior oblongo-lanceolado, falcado, 5-6 × 2-3 mm, ápice agudo, segmento anterior linear, $7-11 \mathrm{~mm}$ compr., ápice agudo; labelo tripartido, segmentos laterais lineares, 1-1,3 cm compr., ápice agudo, segmento mediano estreito-oblongo, 7-8 $\times 1 \mathrm{~mm}$, ápice obtuso, calcar subereto, 2,3-3,2 cm compr. Ginostêmio ca. $2 \mathrm{~mm}$ compr. Ovário + pedicelo $1,3-1,9 \mathrm{~cm}$ compr. Fruto não visto.

Material examinado: em direção à antena, 12.I.2003, fl., A.O. Araujo et al. 338 (ESA); ca. de 10,6 km do entroncamento com a MG-443, no entorno do cume da serra, 5.III.2008, fl., J.A.N. Batista 2621 (BHCB); Sine loco, 23.I.2014, fl., T.L. Vieira 171 (SP).

Habenaria caldensis é endêmica do Brasil, com distribuição conhecida para os estados da Bahia, Goiás e Minas Gerais (Batista et al. 2011a; BFG 2015). Na SOB foi encontrada em campo limpo. Floresce entre janeiro e março. Diferencia-se das demais espécies do gênero na SOB pelas flores alvas e o calcar bem desenvolvido e evidente, muito maior que ovário + pedicelo. Outra característica geralmente observada, sobretudo nas plantas maiores, é o caule levemente sinuoso.

17.3. Habenaria crucifera Rchb.f. \& Warm., Otia. Bot. Hamburg. 2: 80. 1881 Fig. 6d Terrícola, 32-61 cm alt. Folhas eretas, adpressas ao caule, membranáceas, linearlanceoladas, 4,6-10 × 0,3-0,6 cm, ápice agudo. Inflorescência laxa; pedúnculo $2,3-5,5 \mathrm{~cm}$ compr., raque 5,5-12,5 cm compr.; brácteas linearlanceoladas a ovado-lanceoladas, $0,9-4 \times 0,4-0,6$ 
$\mathrm{cm}$, ápice agudo a longamente acuminado. Flores verdes; sépala dorsal ovada, 6-7 × 4-5 mm, ápice agudo a apiculado; sépalas laterais lanceoladofalcadas, $8-9 \times 3 \mathrm{~mm}$, ápice apiculado; pétalas com segmento posterior lanceolado-falcado, 6-7 $\times 2 \mathrm{~mm}$, ápice agudo, segmento anterior reduzido a um dentículo, ca. $1 \mathrm{~mm}$ compr., ápice obtuso; labelo tripartido, segmentos laterais lineares, 8-14 mm compr., ápice agudo, segmento mediano estreito-oblongo, $9-10 \times 1 \mathrm{~mm}$, ápice obtuso, calcar subereto, $0,8-1,2 \mathrm{~cm}$ compr. Ginostêmio $2-3 \mathrm{~mm}$ compr. Ovário + pedicelo 1,1-1,6 cm compr. Fruto não visto.

Material examinado: ca. 2,6 km do entroncamento com a MG-443, 5.III.2008, fl., J.A.N. Batista 2607 (BHCB); próximo às antenas, 18.III.2014, fl., T.L. Vieira 191 (SP).

Habenaria crucifera é endêmica do Brasil, com distribuição conhecida para os estados da Bahia, Goiás, Minas Gerais e São Paulo, além do Distrito Federal (Batista et al. 2011a; BFG 2015). Na SOB foi encontrada em campo limpo seco e campo limpo associado a campo rupestre. Floresce em março. Tem como características úteis para identificação as folhas eretas e notavelmente adpressas ao caule, dando à planta um aspecto quase áfilo, bem como as pétalas com segmentos anteriores reduzidos a dentículos e o labelo com os segmentos laterais e mediano bem desenvolvidos, sendo os laterais projetados lateralmente formando um ângulo quase reto com o mediano.

17.4. Habenaria guilleminii Rchb.f., Linnaea 19: 375. 1847.

Fig. 6e

Terrícola, 10-19,5 cm alt. Folhas da base suberetas e do ápice eretas, membranáceas, elíptico-lanceoladas a lanceoladas, 1,2-3,5 × 0,5$1,4 \mathrm{~cm}$, ápice apiculado. Inflorescência congesta; pedúnculo $1,1-2,5 \mathrm{~cm}$ compr., raque $4-8,3 \mathrm{~cm}$ compr.; brácteas ovado-lanceoladas, 0,6-2 × 0,2$0,8 \mathrm{~cm}$, ápice longamente acuminado a aristado. Flores verdes; sépala dorsal largo-ovada, ca. $4 \times$ $5 \mathrm{~mm}$, ápice apiculado; sépalas laterais elípticolanceoladas, ca. $5 \times 2 \mathrm{~mm}$, ápice apiculado; pétalas com segmento posterior oblongo-lanceolado, falcado, ca. $5 \times 1 \mathrm{~mm}$, ápice obtuso, segmento anterior reduzido a um dentículo, ca. $1 \mathrm{~mm}$ compr., ápice obtuso; labelo tripartido, segmentos laterais lineares, ca. $5 \mathrm{~mm}$ compr., ápice agudo, segmento mediano estreito-oblongo com uma sutil constrição na base, ca. $4 \times 1 \mathrm{~mm}$, ápice obtuso, calcar inconspícuo, ca. $1 \mathrm{~mm}$ compr. Ginostêmio ca. 1 $\mathrm{mm}$ compr. Ovário + pedicelo ca. $8 \mathrm{~mm}$ compr. Fruto fusiforme, ca. $6 \times 3 \mathrm{~mm}$.
Material examinado: ca. de $7 \mathrm{~km}$ do entroncamento com a MG-443, 5.III.2008, fl. e fr., J.A.N. Batista 2613 (BHCB).

Habenaria guilleminii tem distribuição conhecida para os estados de Goiás, Minas Gerais, São Paulo, da Região Sul, além do Distrito Federal, ocorrendo também na Argentina, Paraguai e Uruguai (Batista et al. 2011a; BFG 2015). Na SOB foi encontrada em campo limpo estacionalmente úmido. Floresce em março. Pode ser diferenciada das demais espécies do gênero na SOB pelo porte pequeno das plantas, a inflorescência congesta, o labelo com os segmentos laterais ligeiramente maiores que o mediano, bem como o calcar, que é característica marcante da espécie, extremamente reduzido (ca. $1 \mathrm{~mm}$ compr.).

17.5. Habenaria aff. guilleminii Rchb.f., Linnaea 19: 375.1847.

Fig. $6 f$

Terrícola, ca. $27 \mathrm{~cm}$ alt. Folhas da base suberetas e do ápice eretas, membranáceas, elíptico-laceoladas a ovado-lanceoladas, 1,9-6 $\times 0,5-1,4 \mathrm{~cm}$, ápice apiculado a longamente acuminado. Inflorescência subcongesta; pedúnculo ca. 1,9 cm compr., raque ca. $6,5 \mathrm{~cm}$ compr.; brácteas ovado-lanceoladas, $0,7-1,4 \times 0,3-0,4 \mathrm{~cm}$, ápice longamente acuminado a aristado. Flores verdeclaras; sépala dorsal largo-ovada, ca. $4 \times 4 \mathrm{~mm}$, ápice apiculado; sépalas laterais lanceoladas, ca. $5 \times 3 \mathrm{~mm}$, ápice apiculado; pétalas com segmento posterior lanceolado-falcado, ca. $4 \times 1,5 \mathrm{~mm}$, ápice agudo, segmento anterior reduzido à um dentículo, ca. $1 \mathrm{~mm}$ compr., ápice obtuso; labelo tripartido, segmentos laterais lineares, ca. $5 \mathrm{~mm}$ compr., ápice agudo, segmento mediano estreito-oblongo, ca. 4 $\times 1 \mathrm{~mm}$, ápice acuminado e torcido lateralmente, calcar subereto, ca. $4 \mathrm{~mm}$ compr. Ginostêmio ca. $2 \mathrm{~mm}$ compr.

Material examinado: estrada velha Ouro Branco - Ouro Preto, ca. 6 km de Ouro Branco, 8.III.1995, fl., V.C. Souza et al. 7907 (ESA).

O exemplar analisado é morfologicamente similar a Habenaria guilleminii, sendo, no entanto, um pouco maior, se comparado aos materiais aqui tratados por esse nome, além de apresentar o calcar mais longo (ca. $4 \mathrm{~mm}$ compr.). As peças florais apresentam morfologia e dimensões muito similares a $H$. guilleminii, com exceção do labelo que apresenta os segmentos laterais formando ângulo um pouco mais aberto com o mediano, além do ápice deste último que é torcido e acuminado (vs. obtuso). Com as informações disponíveis no momento não foi possível chegar a uma decisão definitiva quanto 
à identidade desta planta. Foi coletada em campo rupestre arenoso, florida em março.

17.6. Habenaria humilis Cogn., Fl. Bras. 3(4): 67. 1893.

Fig. $6 \mathrm{~g}$

Terrícola, 7,5-22,5 cm alt. Folhas da base suberetas e do ápice eretas, membranáceas, linearlanceoladas, $1-8 \times 0,2-0,4 \mathrm{~cm}$, ápice agudo. Inflorescência laxa; pedúnculo 1,3-4 cm compr., raque 2,5-7,2 cm compr.; brácteas linear-lanceoladas a ovado-lanceoladas, $0,3-1,8 \times 0,1-0,3 \mathrm{~cm}$, ápice acuminado a longamente acuminado. Flores verdes; sépala dorsal largo-ovada, 4-5 × 4-5 mm, ápice obtuso; sépalas laterais elíptico-falcadas, 5-6 $\times 3$ $\mathrm{mm}$, ápice obtuso; pétalas bipartidas, segmento posterior espatulado a estreito-oblongo, falcado, 4-5 $\times 1 \mathrm{~mm}$, ápice obtuso, segmento anterior linear, 4-6 mm compr., ápice obtuso; labelo tripartido segmentos laterais estreito-oblongos, 6-8 $\mathrm{mm}$ compr., ápice obtuso, segmento mediano estreitooblongo, 4-5 × 1-2 mm, ápice obtuso, calcar curvado, 1,1-1,2 cm compr. Ginostêmio 2-3 mm compr. Ovário + pedicelo 1,4-1,5 cm compr. Fruto não visto.

Material examinado: ca. de 10,6 km do entroncamento com a MG-443, no entorno do cume da serra, 5.III.2008, fl., J.A.N. Batista 2619 (BHCB).

Habenaria humilis é endêmica do Brasil, com distribuição conhecida para os estados da Bahia, Goiás, Minas Gerais, Paraná e Rondônia (BFG 2015). Na SOB foi encontrada em campo limpo estacionalmente úmido, associado a campo rupestre. Floresce em março. Tem como características úteis para identificação as folhas linear-lanceoladas, o calcar curvado e o labelo que se apresenta tripartido apenas a partir de 1/3 de seu comprimento.

17.7. Habenaria imbricata Lindl., Gen. Sp. Orchid. P1. 313. 1835.

Fig. $6 \mathrm{~h}$

Terrícola, $17-25 \mathrm{~cm}$ alt. Folhas da base suberetas e do ápice eretas, membranáceas, oblongolanceoladas a lanceoladas, $1,7-5,5 \times 0,5-1,3 \mathrm{~cm}$, ápice agudo. Inflorescência congesta; pedúnculo 0,5-1,5 cm compr., raque 4,5-8 cm compr.; brácteas lanceoladas, $0,8-1,5 \times 0,4-0,6 \mathrm{~cm}$, ápice longamente acuminado. Flores alvo-esverdeadas a verdes; sépala dorsal ovada, 4-4,5 ×3 mm, ápice apiculado; sépalas laterais lanceolado-falcadas, ca. $5 \times 2 \mathrm{~mm}$, ápice apiculado; pétalas bipartidas, segmento posterior lanceolado-falcado, ca. $4 \times 1 \mathrm{~mm}$, ápice agudo, segmento anterior linear, ca. $4 \mathrm{~mm}$ compr., ápice agudo; labelo tripartido, segmentos laterais lineares, 3-4 mm compr., ápice agudo, segmento mediano estreito-oblongo, 3-4 × 0,5-1 mm, ápice agudo, calcar subereto, ca. $7 \mathrm{~mm}$ compr. Ginostêmio 1-2 mm compr. Ovário + pedicelo 1-1,4 cm compr. Fruto não visto.

Material examinado: ca. de 10,6 km do entroncamento com a MG-443, no entorno do cume da serra, 5.III.2008, fl., J.A.N. Batista 2623 (BHCB); lajeado, 14.II.2009, fl., G.E. Valente \& A.A. Azevedo 2445 (VIC, SP).

Habenaria imbricata é endêmica do Brasil, com distribuição conhecida para os estados de Goiás, Minas Gerais, Rio Grande do Sul e São Paulo, além do Distrito Federal (Batista et al. 2011a; BFG 2015). Na SOB foi coletada em campo limpo úmido. Floresce entre fevereiro e março. Apresenta como características úteis para a identificação: a inflorescência congesta, com brácteas bem desenvolvidas, cobrindo a raque, as flores de tamanho reduzido, além do labelo que apresenta os segmentos laterais e mediano com, aproximadamente, o mesmo comprimento.

17.8. Habenaria josephensis Lindl., Gen. Sp. Orchid. 2: 257. 1882.

Fig. $6 \mathrm{i}$

Terrícola, 66-103 cm alt. Folhas da base patentes, tornando-se suberetas a eretas em direção ao ápice, membranáceas, lanceoladas, 1,8-13 × 0,5$2,3 \mathrm{~cm}$, ápice agudo. Inflorescência laxa; pedúnculo 1,6-3,5 cm compr., raque 16-22 cm compr.; brácteas lanceoladas, 1-2 ×0,3-0,6 cm, ápice agudo. Flores verdes; sépala dorsal largo-ovada, 3-4 × 3-4 mm, ápice obtuso; sépalas laterais ovado-falcadas, 4-6× 2-3 mm, ápice obtuso; pétalas bipartidas, segmento posterior oblongo-lanceolado, falcado, 3-4 × 1-2 $\mathrm{mm}$, ápice obtuso, segmento anterior estreitooblongo, às vezes reduzido a um dentículo, 1-2 mm compr., ápice agudo; labelo com segmentos laterais reduzidos a dentículos, ca. $1 \mathrm{~mm}$ compr., ápice obtuso, segmento mediano estreito-oblongo, 6-8 $\times$ $1 \mathrm{~mm}$, ápice arredondado, calcar subereto, 0,9-1,2 cm compr. Ginostêmio ca. 2 mm compr. Ovário + pedicelo ca. $1,5 \mathrm{~cm}$ compr. Fruto não visto.

Material examinado: Área 3, 18.V.2003, fl., C.C. de Paula et al. 813 (VIC); mata de galeria próximo às antenas, 14.IX.2013, fl. cult. II.2014, T.L. Vieira 155 (SP); Sine loco, 17.III.2014, fl., T.L. Vieira 183 (SP, BHCB).

Habenaria josephensis é endêmica do Brasil, com distribuição conhecida para os estados do Alagoas, Bahia, Paraíba, Pernambuco, e das regiões Sudeste e Sul (Batista et al. 2011a; BFG 2015). Na SOB é comumente encontrada nas matas de galeria e na Floresta Estacional Semidecidual. Floresce entre fevereiro e março. É facilmente distinguível das demais espécies do gênero que ocorrem na SOB pela altura elevada das plantas, as folhas variegadas, 
patentes na base do caule, a inflorescência laxa e longa, além do labelo cujos segmentos laterais são reduzidos a dentículos.

17.9. Habenaria lavrensis Hoehne, Arq. Bot. Estad. S. Paulo 1(4): 575, t. 1. $1927 . \quad$ Fig. 6j

Terrícola, 16,5-44 cm alt. Folhas suberetas, membranáceas, lineares a linear-lanceoladas, $2,5-12,5 \times 0,1-0,2 \mathrm{~cm}$, ápice agudo. Inflorescência laxa; pedúnculo $1,3-4,5 \mathrm{~cm}$ compr., raque 3-7,5 cm compr.; brácteas estreito-lanceoladas a ovadolanceoladas, $1,1-3 \times 0,2-0,7 \mathrm{~cm}$, ápice longamente acuminado a aristado. Flores alvas; sépala dorsal ovada, $10-11 \times 6 \mathrm{~mm}$, ápice acuminado; sépalas laterais lanceolado-falcadas, $10-12 \times 3-4 \mathrm{~mm}$, longamente acuminadas, reflexas; pétalas bipartidas, segmento posterior elíptico-lanceolado, falcado, 9-10 $\times 2 \mathrm{~mm}$, ápice agudo, segmento anterior linear, 15-19 mm compr., ápice agudo; labelo tripartido, segmentos laterais lineares, $1,5-1,8 \mathrm{~cm}$ compr., ápice agudo, segmento mediano linear-lanceolado, $1,2-1,3 \times 0,1 \mathrm{~cm}$, ápice agudo, calcar subereto, $1,6-1,8 \mathrm{~cm}$ compr. Ginostêmio 3-4 mm compr. Ovário + pedicelo 2-2,3 cm compr. Fruto não visto. Material examinado: Estrada velha Ouro Branco - Ouro Preto, ca. de $6 \mathrm{~km}$ de Ouro Branco, 8.III.1995, fl., V.C. Souza et al. 7904 (ESA, SP); Área 1, 4.IV.2003, fl., C.C. de Paula et al. 751 (VIC); porção leste da serra, próximo às antenas, 17.III.2014, fl., T.L. Vieira 180 (SP, BHCB); Descida dos Jesuítas, 18.III.2014, fl., T.L. Vieira 190 (SP); 18.III.2014, fl., T.L. Vieira 193 (SP).

Habenaria lavrensis é endêmica do Brasil, com distribuição conhecida para os estados de Goiás e Minas Gerais, além do Distrito Federal (Batista et al. 2011a; BFG 2015). Na SOB foi encontrada em campo limpo e campo limpo associado a campo rupestre. Geralmente floresce em março. Pode ser facilmente diferenciada das demais espécies do gênero na área de estudo, pelas flores completamente alvas, com segmentos longos, e pelas folhas lineares. Outra característica marcante é o tamanho da sépala dorsal, que, proporcionalmente, é mais desenvolvida que as demais peças do perianto.

17.10. Habenaria melanopoda Hoehne \& Schltr., Anexos Mem. Inst. Butantan, Secç. Bot. 1(2): 20, t. 2, fig. 1. 1921.

Fig. 6k

Terrícola, 25-34 cm alt. Folhas da base suberetas e do ápice eretas, membranáceas, linear-lanceoladas, 3,5-8,5 × 0,2-0,4 cm, ápice agudo. Inflorescência laxa; pedúnculo 4,5-6,5 cm compr., raque $10-12,5 \mathrm{~cm}$ compr.; brácteas linear-lanceoladas a lanceoladas, $0,8-3,7 \times 0,2-0,3$ $\mathrm{cm}$, ápice longamente acuminado. Flores verdes; sépala dorsal largo-lanceolada, ca. $5 \times 2,5 \mathrm{~mm}$, ápice agudo; sépalas laterais lanceolado-falcadas, ca. $5 \times 2 \mathrm{~mm}$, ápice apiculado; pétalas bipartidas, segmento posterior oblongo-lanceolado, falcado, ca. $5 \times 1 \mathrm{~mm}$, ápice agudo, segmento anterior linear, ca. $4 \mathrm{~mm}$ compr., ápice agudo; labelo tripartido, segmentos laterais lineares, 4-5 $\mathrm{mm}$ compr., ápice obtuso, segmento mediano estreito-oblongo, ca. $6 \times 1 \mathrm{~mm}$, ápice obtuso, calcar subereto, ca. 1,5 $\mathrm{cm}$ compr. Ginostêmio ca. $2 \mathrm{~mm}$ compr. Ovário + pedicelo ca. $2,1 \mathrm{~cm}$ compr. Fruto não visto.

Material examinado: ca. de $7 \mathrm{~km}$ do entroncamento com a MG-443, 5.III.2008, fl., J.A.N. Batista 2612 (BHCB).

Habenaria melanopoda é endêmica do Brasil, com distribuição conhecida para os estados das regiões Sudeste (exceto Espírito Santo) e Sul (Batista et al. 2011b; BFG 2015). Na SOB foi coletada em campo limpo úmido, com flores em março. Distingue-se das demais espécies do gênero ocorrentes na SOB, pelas folhas linear-lanceoladas, inflorescência laxa e labelo, com segmentos laterais mais curtos que o mediano.

17.11. Habenaria nasuta Rchb.f. \& Warm., Otia Bot. Hamburg. 2: 80. 1881.

Fig. $7 \mathrm{a}$

Terrícola, ca. $66 \mathrm{~cm}$ alt. Folhas eretas, membranáceas, lanceoladas, $11,5-16 \times 1 \mathrm{~cm}$, ápice agudo. Inflorescência laxa; pedúnculo ca. $5,5 \mathrm{~cm}$ compr., raque ca. $16 \mathrm{~cm}$ compr.; brácteas ovadolanceoladas a ovadas, $1,8-5,6 \times 1-1,5 \mathrm{~cm}$, ápice longamente acuminado. Flores verde-amareladas; sépala dorsal ovada, ca. $1,4 \times 1 \mathrm{~cm}$, ápice apiculado; sépalas laterais ovado-lanceoladas, 1,5-1,6 $\times$ 0,6-0,7 cm, ápice apiculado; pétalas bipartidas, segmento posterior lanceolado-falcado, 1,4-1,6 $\times 0,3 \mathrm{~cm}$, ápice agudo, segmento anterior lineartriangular, ca. $3 \mathrm{~cm}$ compr., ápice agudo; labelo tripartido, segmentos laterais linear-lanceolados, 2,6-3 cm compr., ápice agudo, segmento mediano estreito-oblongo, ca. $2 \times 0,2 \mathrm{~cm}$, ápice obtuso, calcar subereto, ca. 2,1 cm compr. Ginostêmio ca. $3 \mathrm{~mm}$ compr. Ovário + pedicelo ca. $3,2 \mathrm{~cm}$ compr. Fruto não visto.

Material examinado: próximo às antenas da Embratel, lado da vista para a cidade, 18.V.2008, fl., G.E. Valente \& A.A. Azevedo 2254 (VIC, SP).

Habenaria nasuta é endêmica do Brasil, com distribuição conhecida para os estados de Goiás e Minas Gerais, além do Distrito Federal (Batista et al. 2011b; BFG 2015). Na SOB foi coletada em campo rupestre. Floresce em maio. Pode ser diferenciada das demais espécies do gênero na área 

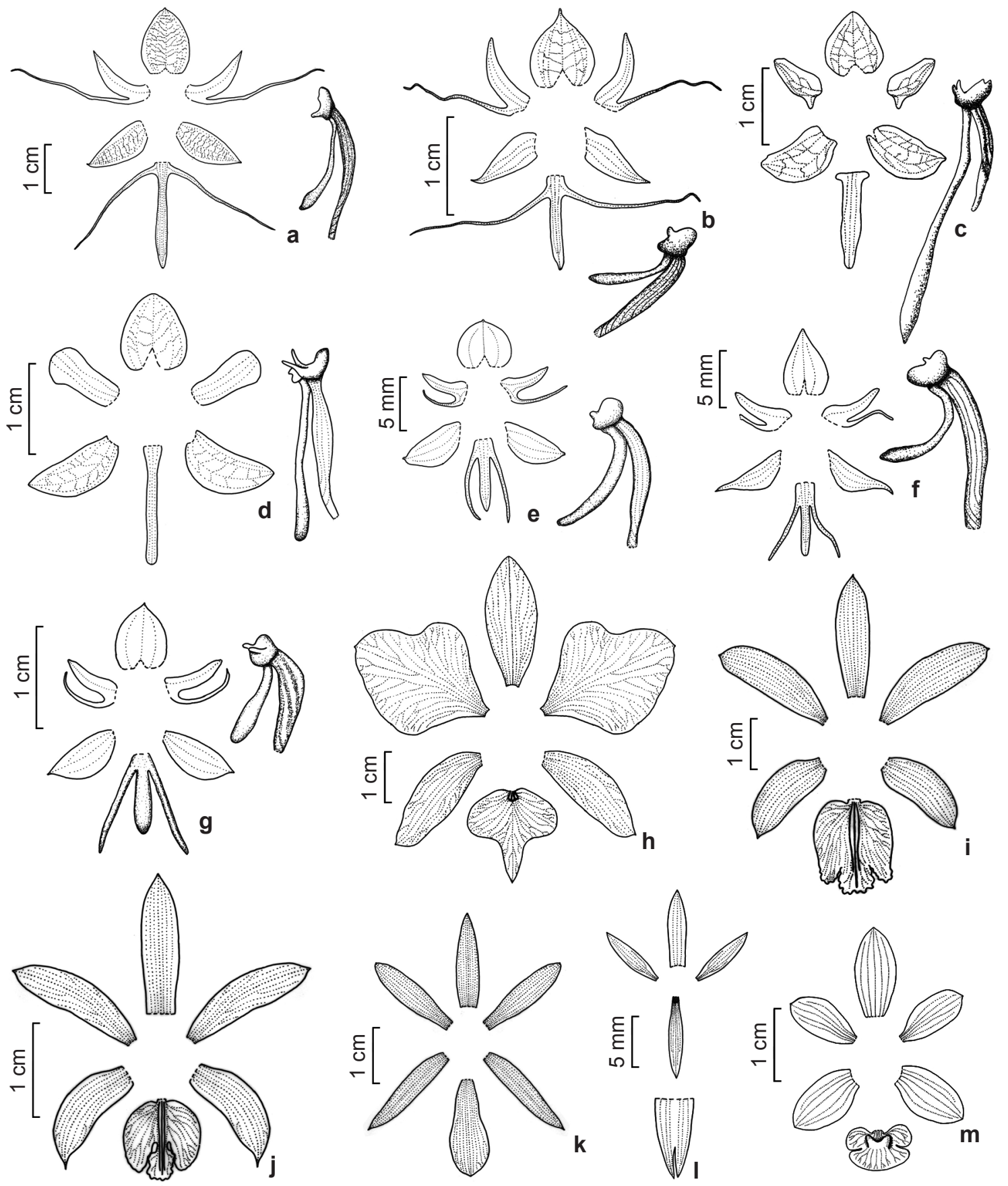

Figura 7 - Periantos dissecados. a. Habenaria nasuta (Valente \& Azevedo 2254). b. Habenaria nuda var. pygmaea (de Paula et al. 219). c. Habenaria obtusa (Caiafa \& Meireles 121). d. Habenaria petalodes (Pereira \& Pabst 2953). e. Habenaria cf. rupicola (Batista 2611). f. Habenaria secundiflora (Batista 2618). g. Habenaria subviridis (Souza et al. 7905). h. Hadrolaelia brevipedunculata (Vieira 200). i. Hoffmannseggella crispata (Vieira 256).j. Hoffmannseggella liliputana (Vieira 138). k. Isabelia violacea (Alves \& Becker 1496). 1. Isochilus linearis (Vieira 206). m. Koellensteinia eburnea (Hoehne s/n).

Figure 7 -Dissected perianths. a. Habenaria nasuta (Valente \& Azevedo 2254). b. Habenaria nuda var. pygmaea (de Paula et al. 219). c. Habenaria obtusa (Caiafa \& Meireles 121). d. Habenaria petalodes (Pereira \& Pabst 2953). e. Habenaria cf. rupicola (Batista 2611). f. Habenaria secundiflora (Batista 2618). g. Habenaria subviridis (Souza et al. 7905). h. Hadrolaelia brevipedunculata (Vieira 200). i. Hoffmannseggella crispata (Vieira 256). j. Hoffmannseggella liliputana (Vieira 138). k. Isabelia violacea (Alves \& Becker 1496). 1. Isochilus linearis (Vieira 206). m. Koellensteinia eburnea (Hoehne $s / n$ ). 
de estudo por se tratar de uma planta, em geral, alta ( $>60 \mathrm{~cm}$ alt.), com caule firmemente ereto, apresentando inflorescência com brácteas bem desenvolvidas e flores grandes. Foi tratada como sinônimo de H. nuda Lindl. por Cougniaux (1893) e Hoehne (1940), no entanto, mais tarde foi observado que $H$. nasuta circunscreve plantas maiores que se enquadram nas características mencionadas anteriormente (Batista 2011b).

17.12. Habenaria nuda var. pygmaea Hoehne, Relat. Comiss. Linhas Telegr. Estrtég. Mato Grosso Amazonas (5): 25, t. 1. 1910.

Fig. $7 b$

Terrícola, 41-46,5 $\mathrm{cm}$ alt. Folhas eretas, adpressas ao caule, membranáceas, lanceoladas, $3,3-10 \times 0,4-0,8 \mathrm{~cm}$, ápice agudo a longamente atenuado. Inflorescência subcongesta; pedúnculo 1,3-2,4 cm compr., raque 4,5-8 cm compr.; brácteas lanceoladas a ovado-lanceoladas, $1,5-2,9 \times 0,5-0,8$ $\mathrm{cm}$, ápice longamente acuminado a aristado. Flores verdes; sépala dorsal largo-ovada, 8-10 × 6-7 mm, ápice apiculado; sépalas laterais lanceoladas, $8-11$ $\times$ 3-4 mm, ápice apiculado; pétalas bipartidas, segmento posterior triangular-lanceolado, falcado, 8-10 $\times 2 \mathrm{~mm}$, ápice agudo, segmento anterior linear, 1,3-1,6 cm compr., ápice agudo; labelo tripartido, segmentos laterais lineares, 1,3-1,9 cm compr., ápice agudo, segmento mediano estreito-oblongo, $0,8-1,1 \times 0,1-0,2 \mathrm{~cm}$, ápice obtuso, calcar subereto, 9-10 mm compr. Ginostêmio ca. $3 \mathrm{~mm}$ compr. Ovário + pedicelo ca. $1,3 \mathrm{~cm}$ compr. Fruto não visto. Materal examinado: Área 2, 4.VIII.2002, fl., C.C. de Paula et al. 219 (VIC).

Habenaria nuda var. pygmaea é endêmica do Brasil, com distribuição conhecida para os estados de Goiás, Minas Gerais, Mato Grosso e São Paulo, além do Distrito Federal (Batista et al. 2011b; BFG 2015). Na SOB foi coletada em campo limpo úmido e ambiente paludoso. Floresce em agosto, período de floração que pode ser considerado peculiar para Habenaria e uma característica desta espécie. Pode ser diferenciada das demais espécies do gênero na SOB pelas folhas adpressas ao caule, bem como pelos segmentos anteriores das pétalas e segmentos laterais do labelo bem desenvolvidos. Batista (2011b) comenta que $H$. nuda var. pygmaea é, de fato, um táxon distinto, mas que sua circunscrição como uma variedade de $H$. nuda ainda é incerta.

17.13. Habenaria obtusa Lindl., Gen. Sp. Orchid. Pl. 315. 1835.

Fig. 7c

Terrícola, 44-49 cm alt. Folhas da base suberetas e do ápice eretas, membranáceas, oblongo-lanceoladas a ovado-lanceoladas, 3-8,5 × 1,1-1,8 cm, ápice agudo. Inflorescência subcongesta; pedúnculo 1,9-2,5 cm compr., raque $12-15,5 \mathrm{~cm}$ compr.; brácteas ovado-lanceoladas a ovadas, $1,7-3 \times 0,8-1,2 \mathrm{~cm}$, ápice agudo. Flores verdes; sépala dorsal largo-ovada, 7-8 × 7-9 mm, ápice obtuso; sépalas laterais elíptico-falcadas, 9-10 × 5-6 mm, ápice agudo; pétalas com segmento posterior oblongo-falcado, $7 \times 2-3 \mathrm{~mm}$, ápice obtuso, segmento anterior reduzido a um dentículo, ca. $1 \mathrm{~mm}$ compr., ápice obtuso; labelo inteiro, estreito-oblongo, $12-13 \times 2-3 \mathrm{~mm}$, ápice arredondado, calcar subereto, 3-3,3 cm compr. Ginostêmio 3-4 mm compr. Ovário + pedicelo $1,4-1,6 \mathrm{~cm}$ compr. Fruto não visto.

Material examinado: 1.III.2001, fl., A.N. Caiafa \& L.D. Meireles 121 (VIC); ca. de $7 \mathrm{~km}$ do entroncamento com a MG-443, 5.III.2008, fl., J.A.N. Batista 2610 (BHCB).

Habenaria obtusa pode ser encontrada no norte da América do Sul e apresenta ampla distribuição no Brasil, ocorrendo nos estados de Alagoas, Bahia, Maranhão, Minas Gerais, Pará, Paraíba, Paraná, Pernambuco, Piauí, Rondônia, Roraima, São Paulo, Sergipe e Tocantins, e da Região Centro-Oeste, além do Ditrito Federal (Batista et al. 2011b; BFG 2015). Na SOB foi encontrada em campo limpo, florescendo em março. Difere das demais espécies do gênero na SOB pelo aspecto folioso da planta, com brácteas e calcar bem desenvolvidos (este maior que $3 \mathrm{~cm}$ compr.), sépala dorsal com ápice obtuso e labelo inteiro, com ápice arredondado.

17.14. Habenaria petalodes Lindl., Gen. Sp. Orchid. Pl.: 316. $1835 . \quad$ Fig. 7d

Terrícola, ca. $108 \mathrm{~cm}$ alt. Folhas da base patentes, tornando-se suberetas a eretas em direção ao ápice do caule, membranáceas, oblongolanceoladas a lanceoladas, 5,5-13 × 1-2 cm, ápice agudo. Inflorescência laxa; pedúnculo ca. 4,5 $\mathrm{cm}$ compr., raque ca. $31,5 \mathrm{~cm}$ compr.; brácteas lanceoladas, 1,3-4,5 × 0,4-1,2 ápice longamente acuminado. Flores esverdeadas; sépala dorsal largoovada, ca. $9 \times 7 \mathrm{~mm}$, ápice arredondado; sépalas laterais elíptico-falcadas, $10-11 \times 5 \mathrm{~mm}$, ápice agudo; pétalas inteiras, espatuladas, $8-10 \times 4-5 \mathrm{~mm}$, ápice arredondado a subtruncado; labelo inteiro, estreito-oblongo a oblongo-lanceolado, 12-16 $\times$ 1-2 mm, ápice arredondado, calcar subereto, 1,8-2 cm compr.. Ginostêmio 4-5 mm compr. Ovário + pedicelo 1,7-2,1 cm compr. Fruto não visto.

Material examinado: Sine loco, 17.IV.1957, fl., E. Pereira \& Pabst 2953 (RB). 
Habenaria petalodes tem distribuição conhecida para os estados da Bahia, Ceará, Goiás, Maranhão, Mato Grosso do Sul, Pará, Paraíba, Pernambuco e Sergipe, e da Região Sudeste, além do Distrito Federal, ocorrendo também no Paraguai (Batista et al. 2011b; BFG 2015). Floresce em abril. A espécie é facilmente diferenciada das demais Habenaria na SOB pela morfologia floral, com pétalas inteiras e espatuladas, de ápice arredondado a subtruncado, e labelo inteiro.

17.15. Habenaria cf. rupicola Barb.Rodr., Rev. Engenh. 3: 144. 1881.

Fig. $7 \mathrm{e}$

Terrícola, 25-40 $\mathrm{cm}$ alt. Folhas da base suberetas e do ápice eretas, membranáceas, elíptico-lanceoladas a lanceoladas, 2,5-8 × 0,5-1,6 $\mathrm{cm}$, ápice apiculado a longamente acuminado. Inflorescência laxa; pedúnculo 2,5-3,8 cm compr., raque $5-13,5 \mathrm{~cm}$ compr.; brácteas lanceoladas a ovado-lanceoladas, $0,6-1,8 \times 0,2-0,4 \mathrm{~cm}$, ápice longamente acuminado. Flores verdes; sépala dorsal subcircular a largo-ovada, 5-6 $\times$ 4-5 $\mathrm{mm}$, ápice apiculado; sépalas laterais lanceoladas, levemente falcadas, 6-7×3 mm, ápice apiculado; pétalas bipartidas, segmento posterior oblongo-lanceolado, falcado, 4-6 × 1-1,5 mm, ápice agudo, segmento anterior linear, $5-7 \mathrm{~mm}$ compr., ápice agudo; labelo tripartido, segmentos laterais lineares, 6-7 mm compr., ápice agudo, segmento mediano estreito-oblongo, 5-6 $\times 1 \mathrm{~mm}$, ápice obtuso, calcar subereto, 8-11 $\mathrm{mm}$ compr.. Ginostêmio 2-3 mm compr. Ovário + pedicelo $1-1,4 \mathrm{~cm}$ compr. Fruto não visto.

Material examinado: ca. de $7 \mathrm{~km}$ do entroncamento com a MG-443, 5.III.2008, fl., J.A.N. Batista 2611 (BHCB).

A identidade deste material é incerta, tratando-se de uma espécie bem próxima a Habenaria rupicola, que forma um complexo com outras espécies afins como $H$. repens Nutt., $H$. sampaioana Schltr., H. polygonoides Schltr., $H$. polyrhiza Schltr. e H. aranifera Lindl. (Batista et al. 2011b). Há também espécimes referidos para o Itacolomi (Batista et al. 2004) como H. cf. rupicola, que, aparentemente, representam o mesmo táxon encontrado na SOB. Habenaria rupicola é tratada como endêmica de Minas Gerais (Batista et al. 2004, 2011b). De qualquer modo, mais estudos taxonômicos são necessários dentro deste grupo de espécies, a fim de obter-se uma delimitação mais precisa entre os táxons. Na SOB foi encontrada em campo limpo, com flores em março. Distingue-se das demais espécies do gênero na área de estudo, pelas inflorescências laxas, flores pequenas, com segmentos anteriores das pétalas de tamanho igual ou pouco maiores que os segmentos posteriores, bem como os segmentos laterais do labelo, que são do mesmo comprimento ou um pouco maiores que o segmento mediano.

17.16. Habenaria secundiflora Barb.Rodr., Gen. Sp. Orchid. 2: 252. 1882.

Fig. $7 \mathrm{f}$

Terrícola, 16,5-25 cm alt. Folhas linearlanceoladas, $2,2-6 \times 0,2-0,4 \mathrm{~cm}$, ápice agudo a longamente acuminado. Inflorescência laxa; pedúnculo $2-3 \mathrm{~cm}$ compr., raque $3,5-6,5 \mathrm{~cm}$ compr.; brácteas ovado-lanceoladas a elípticolanceoladas, $1-3,5 \times 0,3-0,5 \mathrm{~cm}$, ápice longamente acuminado a aristado. Flores verdes; sépala dorsal ovada, 5-6 × 3-4 mm, ápice obtuso; sépalas laterais lanceolado-falcadas, $6-7 \times 2 \mathrm{~mm}$, ápice apiculado; pétalas bipartidas, segmento posterior lanceoladofalcado, 5-6 × 1-1,5 mm, ápice agudo, segmento anterior linear, ca. $6 \mathrm{~mm}$ compr., ápice obtuso; labelo tripartido, segmentos laterais lineares, 5-6 $\mathrm{mm}$ compr., ápice obtuso, segmento mediano estreito-oblongo, ca. $4 \times 1 \mathrm{~mm}$, ápice obtuso, calcar curvado, 9-10 mm compr. Ginostêmio 2-3 $\mathrm{mm}$ compr. Ovário + pedicelo 1,5-1,9 cm compr. Fruto não visto.

Material examinado: Sine loco, 29.I.1921, fl., F.C. Hoehne (SP); ca. de 10,6 km do entroncamento com a MG-443, 3.V.2008, fl., J.A.N. Batista 2618 (BHCB).

Material adicional examinado: BRASIL. MINAS GERAIS: Ouro Preto, Estrada velha Ouro Branco-Ouro Preto, ca. 16 km de Ouro Branco, 9.III.1995, fl., V.C Souza et al. 8068 (ESA).

Habenaria secundiflora tem distribuição conhecida para os estados de Goiás, Minas Gerais, Pará, Paraná e São Paulo, além do Distrito Federal, ocorrendo também na Colômbia, Guiana, Guiana Francesa e Venezuela (Batista et al. 2011b; BFG 2015). Na SOB foi encontrada em campo limpo. Floresce em março. Pode ser distinguida das demais espécies do gênero na SOB, pelas folhas linear-lanceoladas, inflorescência laxa, flores com calcar curvado e sépalas laterais lanceoladofalcadas, com ápice apiculado.

17.17. Habenaria subviridis Hoehne \& Schltr., Arq. Bot. Estado São Paulo 1(3): 176, t. 1, fig. 1. 1926.

Fig. $7 \mathrm{~g}$

Terrícola, 23,5-34 cm alt. Folhas da base suberetas e do ápice eretas, membranáceas, lanceoladas, 2,6-9 × 0,6-1,2 cm, ápice agudo a longamente acuminado. Inflorescência congesta; 
pedúnculo 1,3-2 cm compr., raque 5,5-12,5 cm compr.; brácteas ovado-lanceoladas 1,2-2,3 $\times$ $0,4-0,8 \mathrm{~cm}$, ápice longamente acuminado. Flores verde-claras; sépala dorsal ovada, 7-8 $\times 5-6 \mathrm{~mm}$, ápice obtuso, com apículo dorsal; sépalas laterais lanceoladas, levemente falcadas, $8-9 \times 3 \mathrm{~mm}$, ápice apiculado; pétalas bipartidas, segmento posterior oblongo-lanceolado, falcado, 6-7 $\times$ 1-1,5 mm, ápice agudo, segmento anterior linear, 6-9 mm compr., ápice agudo; labelo tripartido, segmentos laterais lineares, $1-1,1 \mathrm{~cm}$ compr., ápice agudo, segmento mediano estreito-oblongo, $0,75-8 \times 1 \mathrm{~mm}$, ápice obtuso, calcar quase reto, $8-11 \mathrm{~mm}$ compr. Ginostêmio ca. $2 \mathrm{~mm}$ compr. Ovário + pedicelo 9-11 mm compr. Fruto não visto. Material examinado: Sine loco, 18.IV.1957, fl., Pereira \& Pabst 3000 (RB), p.p.; Estrada velha Ouro Branco - Ouro Preto, ca. 6 km de Ouro Branco, 8.III.1995, fl., V.C. Souza et al. 7905 (ESA, SP); 8.III.1995, fl., V.C. Souza et al. 7906 (ESA); Estrada velha Ouro Branco Ouro Preto, ca. 9 km de Ouro Branco, 8.III.1995, fl., V.C. Souza et al. 7947 (ESA, SP); Área 2, 28.II.2003, fl., C.C. de Paula et al. 699 (VIC).

Habenaria subviridis é endêmica do Brasil, com distribuição conhecida para os estados da Bahia, Goiás, Minas Gerais, São Paulo, Rio de Janeiro, Paraná e Santa Catarina (Batista et al. 2011b; BFG 2015). Na SOB foi encontrada em campo rupestre. Floresce entre fevereiro e abril. Tem como características úteis na sua identificação: presença de folhas mais desenvolvidas na base do caule, inflorescência congesta, flores com segmentos anteriores das pétalas de comprimento semelhante ao posterior.

\section{Hadrolaelia (Schltr.) Chiron \& V.P.Castro} 18.1. Hadrolaelia brevipedunculata (Cogn.) Chiron \& V.P.Castro, Richardiana 2: 21. 2002.

Fig. $7 \mathrm{~h}$

Epífita, ocasionalmente saxícola, $5-8 \mathrm{~cm}$ alt. Crescimento simpodial. Raízes filiformes, cobertas por velame. Rizoma curto. Cauloma intumescido em pseudobulbo. Pseudobulbo heteroblástico, globoso a fusiforme, $0,8-1,2 \mathrm{~cm}$ compr., 1-foliado. Folha no ápice do pseudobulbo, subereta a patente, conduplicada a plana, coriácea, carnosa, verde, ocasionalmente apresentando pigmentação vinácea, ovada a largo-elíptica, $0,9-2,2 \times 0,8-1,3 \mathrm{~cm}$, séssil, ápice acuminado. Inflorescência terminal, uniflora; pedúnculo 3-4 $\mathrm{mm}$ compr., bráctea do pedúnculo amplectiva, ereta, triangular, ca. $1 \times 2 \mathrm{~mm}$, ápice agudo; bráctea floral triangular 1-2 × 1,5-2 mm, ápice agudo. Flor rosada ou avermelhada, ressupinada, pedicelada, ecalcarada; sépala dorsal elíptica, $1,8-2,8 \times 0,6-1 \mathrm{~cm}$, ápice obtuso; sépalas laterais elíptico-falcadas, $1,3-2,9 \times 0,6-0,9 \mathrm{~cm}$, ápice agudo; pétalas de âmbito obovado, 1,9-3 × 1,2-2,4 $\mathrm{cm}$, ápice obtuso; labelo amarelo no centro e rosado ou avermelhado nas margens e no ápice, trilobado, livre, conduplicado, âmbito largo-ovado, $1,4-1,9 \times 1,4-1,9 \mathrm{~cm}$, calosidade formada por três lamelas longitudinais dispostas na base do labelo; lobos laterais orbiculares, 5-7 × 8-10 mm, ápice arredondado, margem inteira; lobo mediano lanceolado, 5-9 × $4 \mathrm{~mm}$, margem inteira, ápice agudo. Ginostêmio 5-6 mm compr.; antera apical, incumbente, versátil; grãos de pólen aglutinados em polínias. Polínias 8, maciças, providas apenas de caudículas. Ovário + pedicelo $2-3 \mathrm{~cm}$ compr. Fruto não visto.

Material examinado: Sine loco, 25.V.1969, fl., A.P. Duarte 11606 (BHCB); 17.V.1991, fl. M.M.N. Braga \& A.L.F. Chaves 349 (BHCB); 20.IV.2003, f1., L.D. Meireles et al. 1397 (UEC); 1.VIII.2009, fl., J.F. Rodrigues (ESA119238); cume próximo às antenas, na direção Norte, 24.VI.2014, fl., T.L. Vieira 200 (SP).

Hadrolaelia brevipedunculata é endêmica dos campos rupestres de Minas Gerais (BFG 2015), comumente encontrada como epífita sobre indivíduos de Vellozia. Na SOB foi encontrada em torno de $1.500 \mathrm{~m}$ de altitude. Floresce de abril a agosto. Possui inflorescência 1-flora e flor muito vistosa, notoriamente grande em relação à parte vegetativa da planta, de coloração rosada ou avermelhada, com pétalas bem desenvolvidas. Foram encontrados poucos indivíduos, esparsamente localizados ao longo da serra. Aparentemente, isso está ligado a um histórico de coleta predatória da espécie na região, tendo em vista o seu potencial ornamental e apreço dos colecionadores, além do fácil acesso à $\mathrm{SOB}$, a qual apenas recentemente foi reconhecida como Unidade de Conservação. A espécie está ameaçada de extinção de acordo com Menini Neto et al. (2013), sendo tratada na categoria "vulnerável”.

\section{Hoffmannseggella H.G. Jones}

Ervas rupícolas ou saxícolas. Crescimento simpodial. Raízes filiformes, cobertas por velame. Rizoma curto ou inconspícuo. Cauloma intumescido em pseudobulbo. Pseudobulbos heteroblásticos, obclavados ou estreito-ovoides, 1(-2)-foliados. Folhas alternas, dísticas, verdes a vináceas, sésseis. Inflorescência terminal, 1-flora ou em racemo 5-11-floro. Flores pediceladas, ressupinadas, vistosas, lilases ou amarelas, carnosas; sépalas livres, de tamanho semelhante, 
oblongas a elípticas, as laterais falcadas; pétalas livres, elíptico-falcadas, ápice agudo a acuminado; labelo trilobado, livre, calo formado por cristas lamelares longitudinais no centro, lobos laterais envolvendo a coluna, lobo mediano com margem ondulada e, em alguns casos, unguiculado. Ginostêmio claviforme; antera apical, incumbente, versátil; grãos de pólen aglutinados em polínias. Polínias 8, maciças, providas apenas de caudículas. Ovário unilocular. Fruto cápsula.

\section{Chave de identificação para espécies de Hoffmannseggella ocorrentes na Serra do Ouro Branco}

1. Plantas 5-8 cm alt.; inflorescência 1-flora; flores predominantemente lilás-pálidas; labelo 0,9-1 $\times$ 0,9-1 cm 2. Hoffmannseggella liliputana

1'. Plantas > $30 \mathrm{~cm}$ alt.; inflorescência 5-11-flora; flores predominantemente amarelas; labelo 1,7-2,3 × $1,3-1,5 \mathrm{~cm}$.

2. Inflorescência congesta; raque (1,5-)2,5-3,5(-7,5) cm compr.; sépalas laterais oblongo-falcadas; lobo mediano do labelo não unguiculado 1. Hoffmannseggella crispata

2'. Inflorescência laxa; raque ca. 7 cm compr.; sépalas laterais lanceolado-falcadas; lobo mediano do labelo unguiculado 3. Hoffmannseggella sp.

19.1. Hoffmannseggella crispata (Thunb.) H.G. Jones, Hawaii Orchid Journal 3(4): 14. 1974.

Fig. $7 \mathrm{i}$

Rupícola ou saxícola, 33,5-81 cm alt. incluindo a inflorescência. Pseudobulbo estreitoovoide a obclavado, 3,5-14,5 cm compr., geralmente coberto por bainhas escariosas, persistentes, 1-foliado, ocasionalmente 2-foliado. Folha no ápice do pseudobulbo, coriácea, carnosa, variando entre verde e vináceo, elíptica, 8,5-17,5 $\times 1,9-3 \mathrm{~cm}$, séssil, ápice apiculado. Inflorescência em racemo, 5-11-flora; pedúnculo 20,5-55,5 cm compr., base envolvida por espata de (2,7-)5,2-9,3 cm compr.; raque $(1,5-) 2,5-3,5(-7,5) \mathrm{cm}$ compr.; brácteas triangulares, 3-7 × 2-5 mm, ápice agudo. Flores predominantemente amarelas; sépala dorsal oblonga, 2,2-2,9 × 0,5-0,7 cm, ápice agudo a apiculado; sépalas laterais oblongo-falcadas, $2-2,7 \times 0,5-0,7 \mathrm{~cm}$, ápice agudo a apiculado; pétalas elíptico-falcadas $2,2-2,9 \times 0,5-0,8 \mathrm{~cm}$, ápice acuminado a apiculado; labelo trilobado, âmbito oblongo a largo-elíptico, 1,7-2,3 × 1,3-1,5 $\mathrm{cm}$, calosidade amarela, lobos laterais oblongos a subovados, 1,5-1,8 × 0,5-0,6 cm, margem ondulada próximo ao ápice, ápice obtuso, lobo mediano suborbicular, 6-9 × 6-9 mm, margem ondulada, ápice obtuso. Ginostêmio 8-9 mm compr. Ovário + pedicelo 2,2-3,1 cm compr. Fruto não visto.

Material examinado: Sine loco, 2.X.1988, fl., C.M. Braccini (BHCB 13966); 16.VII.1998, fl., A. Rapini et al. 662 (UEC); Área 1, 13.VII.2002, fl., C.C. de Paula et al. 160 (VIC); Área 2, 4.VIII.2002, fl., C.C. de Paula et al. 209 (VIC); 11.VIII.2002, fl., C.C. de Paula 270 (VIC); 11.VIII.2002, fl., C.C. de Paula 271 (VIC); descida da trilha para a gruta, sentido estação da COPASA, 4.XII.2013, fl. cult. IX.2014, T.L. Vieira 256 (SP).

Hoffmannseggella crispata é endêmica dos campos rupestres de Minas Gerais (BFG 2015). $\mathrm{Na} \mathrm{SOB}$ foi encontrada em afloramentos no campo rupestre, ao longo de quase toda extensão da parte alta da serra. Apesar disso, não foram observadas populações densas, mas apenas alguns indivíduos esparsamente distribuídos, o que pode estar associado à coleta predatória de plantas na região. Floresce entre julho e agosto. Hoffmannseggella crispata pode ser reconhecida pela inflorescência de pedúnculo longo, raque congesta a subcongesta e flores relativamente grandes e amarelas.

19.2. Hoffmannseggella liliputana (Pabst) H.G. Jones, Hawaii Orchid Journal 3(4): 16. 1974.

Fig. 7j

Rupícola ou saxícola, 5-8 cm alt. Pseudobulbo globoso a ovoide, 0,5-1 cm compr., 1-foliado. Folha no ápice do pseudobulbo, coriácea, carnosa, variando entre verde e vináceo, elíptica, conduplicada, 1,2-2,2 × 0,5-1 cm, séssil, ápice apiculado. Inflorescência 1-flora; pedúnculo 1,1-2,7 cm compr., base envolvida por espata de 6-12 mm compr.; bráctea floral triangular, 2-4 $\times$ 1,5-2 mm, ápice atenuado. Flor predominantemente lilás-pálido; sépala dorsal oblonga a oblanceolada, $15 \times 3,5-4 \mathrm{~mm}$, ápice agudo a apiculado; sépalas laterais oblongo-falcadas, 1,2-1,3 × 0,4 cm, ápice agudo a apiculado; pétalas elíptico-falcadas, 1,2-1,5 $\times$ 0,3-0,4 cm, ápice agudo; labelo trilobado, âmbito suborbicular a largo-elíptico, 0,9-1 × 0,9-1,0 cm, calosidade amarela, lobos laterais semicirculares a oblongos, $0,8-1 \times 0,3-0,4 \mathrm{~cm}$, margem sutilmente 
sinuosa a erosa, ápice obtuso a arredondado, lobo mediano unguiculado, istmo ca. $1 \mathrm{~mm}$ compr., limbo subquadrado a elíptico, ca. $3 \times 3 \mathrm{~mm}$, margem ondulada, ápice obtuso. Ginostêmio ca. 6 $\mathrm{mm}$ compr. Ovário + pedicelo 1,6-2,3 cm compr. Fruto não visto.

Material examinado: próximo às antenas, 4.XII.2013, fl., T.L. Vieira 162 (SP); Sine loco, 13.IX.2013, fl. cult. X.2014, T.L. Vieira 138 (SP, BHCB).

Hoffmannseggella liliputana é endêmica dos campos rupestre de Minas Gerais (BFG 2015). Na SOB foi encontrada em campo rupestre, acima dos $1.300 \mathrm{~m}$ de altitude. Floresce entre outubro e dezembro. É facilmente diferenciada das demais espécies do gênero pelo tamanho reduzido (5-8 $\mathrm{cm}$ alt.), inflorescência 1-flora e flor com coloração predominantemente lilás-claro, apenas com o calo do labelo amarelo.

\subsection{Hoffmannseggella sp.}

Rupícola ou saxícola, ca. $32 \mathrm{~cm}$ alt. Pseudobulbo obclavado, ca. $6 \mathrm{~cm}$ compr., 1-foliado. Folha no ápice do pseudobulbo, coriácea, carnosa, oblongo-elíptica, ca. 13,5 × 1,3 cm, séssil, ápice apiculado. Inflorescência em racemo, laxa, 6-7-flora; pedúnculo ca. 18,5 cm compr., base envolvida por espata de ca. $5,5 \mathrm{~cm}$ compr.; raque ca. $7 \mathrm{~cm}$ compr.; brácteas triangulares, $3-5 \times 2-3 \mathrm{~mm}$, ápice atenuado. Flores com sépala dorsal oblonga, 2,1-2,4 × 0,4 cm, ápice atenuado e apiculado; sépalas laterais lanceolado-falcadas, 1,8-2,2 $\times$ $0,4-0,5 \mathrm{~cm}$, ápice atenuado e apiculado; pétalas elíptico-falcadas, 2-2,4 ×0,6 cm, ápice apiculado; labelo trilobado, âmbito largo-elíptico, ca. 1,7 × $1,3 \mathrm{~cm}$, calosidade não observada; lobos laterais oblongos, ca. 1,5 × 0,4 cm, margem ondulada próximo no ápice, ápice obtuso; lobo mediano unguiculado, istmo ca. 1,5 mm compr., porção apical largo-oblonga, ca. $6 \times 5,5 \mathrm{~mm}$, margem ondulada, ápice obtuso. Ginostêmio ca. $7 \mathrm{~mm}$ compr. Ovário + pedicelo 2,8-4,2 cm compr. Fruto não visto.

Material examinado: Alto da serra (orla de mata), 13.IX.1989, fl., M.G.V. Torquato et al. (BHCB 17304).

$\mathrm{O}$ exemplar examinado encontra-se bastante deteriorado, não restando nenhum labelo preservado nas flores presentes na exsicata, o que impossibilitou a identificação precisa. Foi possível apenas verificar o âmbito geral da forma do labelo, cujo lobo mediano é unguiculado, com o istmo bem desenvolvido. Aparentemente é uma espécie próxima a H. crispata, no entanto difere pelas características já comentadas anteriormente, bem como pelo porte um pouco mais esguio da planta, a inflorescência laxa e as peças do perianto mais estreitas.
20. Isabelia Barb.Rodr.

20.1. Isabelia violacea (Lindl.) Van den Berg \& M.W.Chase, Lindleyana 16: 109. 2001.

Fig. $7 \mathrm{k}$

Rupícola, 5-7 cm alt. Crescimento simpodial. Raízes filiformes, cobertas por velame. Rizoma curto. Cauloma intumescido em pseudobulbo. Pseudobulbo heteroblástico, fusiforme, 1,2-1,5 $\mathrm{cm}$ compr., 1(2)-foliado. Folha no ápice do pseudobulbo, conduplicada, coriácea, verde, estreito-elíptica, 4-4,5 ×0,3-0,4 cm, séssil, ápice agudo a apiculado. Inflorescência terminal, uniflora; pedúnculo inconspícuo, espata ca. $1 \mathrm{~cm}$ compr.; bráctea floral ovada, escariosa, ca. $5 \times 2,5 \mathrm{~mm}$, ápice agudo. Flor lilás, ressupinada, pedicelada, ecalcarada; sépala dorsal oblonga a lanceolada, ca. $1,7 \times 0,4 \mathrm{~cm}$, ápice agudo; sépalas laterais oblongas, ca. $2 \times 0,4 \mathrm{~cm}$, ápice agudo; pétalas oblongo-elípticas, ca. $18 \times 4,5 \mathrm{~mm}$, ápice obtuso; labelo inteiro, adnato ao ginostêmio apenas na base, obovado, ca. 1,7 ×0,8 cm, ápice obtuso, margem inteira, destituído de calosidade. Ginostêmio ca. $5 \mathrm{~mm}$ compr.; antera apical, incumbente, versátil; grãos de pólen aglutinados em polínias. Polínias 8, providas apenas de caudículas. Ovário + pedicelo 2,5-2,9 cm compr. Fruto não visto.

Material examinado: Cume mais ao sul da serra, 18.IX.1990, fl., R.J.V. Alves \& J. Becker 1496 (RB).

Isabelia violacea é endêmica do Brasil, com distribuição conhecida para os estados da Bahia, Goiás, e das regiões Sudeste e Sul, além do Distrito Federal (BFG 2015). Na SOB foi encontrada sobre canga, no campo rupestre. Floresce em novembro. Pode ser reconhecida, dentre as demais espécies da família para a SOB, pelo pequeno porte (5-7 $\mathrm{cm}$ alt.), inflorescência 1-flora, cuja flor apresenta coloração lilás e labelo inteiro, obovado.

\section{Isochilus R.Br.}

21.1. Isochilus linearis (Jacq.) R.Br., Hort. Kew. ( $2^{\text {nd }}$ ed.) $5: 209.1813$.

Fig. 71

Epífita, 9-34 cm alt. Crescimento simpodial. Raízes filiformes, cobertas por velame. Rizoma 2-5 mm compr., coberto por bainhas escariosas. Cauloma não intumescido em pseudobulbo. Cauloma homoblástico, linear-cilíndrico, coberto pelas bainhas das folhas, $6,5-30 \mathrm{~cm}$ compr., multifoliado. Folhas alternas, dísticas, suberetas, cartáceas, verdes, estreito-oblongas, 4,2-5,4 $\times$ $0,3 \mathrm{~cm}$, base amplexicaule, ápice emarginado, assimétrico. Inflorescência terminal, em racemo, congesta, 3-5-flora; pedúnculo inconspícuo; brácteas do pedúnculo ausentes; raque $2-3 \mathrm{~cm}$ 
compr.; brácteas florais estreito-oblongas, com mesmo aspecto das folhas a elíptico-lanceoladas e escariosas, 8-35 × 2,5-5 mm , ápice emarginado, assimétrico a obtuso. Flores róseas, ressupinadas, pediceladas, ecalcaradas; sépala dorsal oblongolanceolada, ca. $8 \times 2 \mathrm{~mm}$, ápice agudo; sépalas laterais parcialmente adnatas à sépala dorsal, coalescentes em sinsépalo até ca. de $2 / 3$ de sua extensão, lanceoladas, 9-10 × 2,5-3 mm, ápice agudo; pétalas estreito-elípticas, 7-8 × 1,5 mm, ápice agudo; labelo articulado com o pé da coluna, inteiro, estreito-elíptico, sigmoide. $8 \times 1,5 \mathrm{~mm}$, ápice agudo, margem inteira, calo pubescente na base do labelo. Ginostêmio 3-4 mm compr., base projetada em pé de ca. 1,5 mm compr.; antera apical, incumbente, versátil; grãos de pólen aglutinados em polínias. Polínias 4, maciças, providas apenas de caudículas. Ovário + pedicelo 7-12 mm compr; zona de abscisão entre pedicelo e ovário ausente. Fruto fusiforme, 7-12 × 3-4 mm. Material examinado: Sine loco, 26.VI.2014, fr., T.L. Vieira 206 (SP).

Material adicional examinado: BRASIL. MINAS GERAIS: Santa Bárbara, Areião, 7.VII.1921, fl. e fr., F.C. Hoehne (SP).

Isochilus linearis é amplamente distribuída na região neotropical, desde o México até o norte da Argentina (Govaerts et al. 2015). No Brasil é conhecida para os estados do Alagoas, Bahia, Ceará, Mato Grosso do Sul, Pernambuco, Roraima, e das regiões Sudeste e Sul, além do Distrito Federal (BFG 2015). Na SOB foi encontrada em mata da galeria, com frutos abertos em junho. Pode ser reconhecida por seu cauloma não intumescido em pseudobulbo, portando muitas folhas, dispostas dística e alternadamente, estreito-oblongas, além da inflorescência que é curta, pauciflora, portando flores róseas e de aspecto tubular.

\section{Koellensteinia Rchb.f.}

22.1. Koellensteinia eburnea (Barb.Rodr.) Schltr., Orchis 12: 28. 1918.

Fig. $7 \mathrm{~m}$

Terrícola, 38-42 cm alt. Crescimento simpodial. Raízes filiformes, cobertas por velame. Rizoma inconspícuo. Cauloma intumescido em pseudobulbo. Pseudobulbo heteroblástico, obclavado, não formando ângulos em seção transversal, 1,5-2 cm compr., geralmente 1-2-foliado. Folhas no ápice do pseudobulbo, eretas a suberetas, plicadas, cartáceas, verdes, estreito-elípticas, 15,5-26 × 0,9-1,3 cm, base longamente atenuada, ápice agudo. Inflorescência lateral, em racemo, laxa, ca. 9-flora; pedúnculo 27-
$32 \mathrm{~cm}$ compr.; brácteas do pedúnculo escariosas, amplectivas, adpressas, ovadas, 10-12 $\times-6 \mathrm{~mm}$, ápice obtuso; raque $8-9 \mathrm{~cm}$ compr.; brácteas florais triangular-lanceoladas, 3-7 ×2-3 mm, ápice agudo. Flores alvas, maculadas de lilás, ressupinadas, pediceladas, ecalcaradas; sépala dorsal elíptica, 11-13 × 4-6 mm, ápice obtuso; sépalas laterais livres, elípticas, $11-13 \times 5-6 \mathrm{~mm}$, ápice obtuso; pétalas elípticas, $10-11 \times 4,5-5 \mathrm{~mm}$, ápice obtuso a arredondado; labelo unguiculado, articulado com o pé da coluna, trilobado, conduplicado, âmbito transversalmente elíptico a reniforme, $6 \times 9-10$ $\mathrm{mm}$, calo bilobado, disposto transversalmente na base do labelo; lobos laterais suborbiculares, ca. 3 $\times 3 \mathrm{~mm}$, ápice arredondado, margem inteira; lobo mediano transversalmente elíptico, 2,5-3 × 8-9 $\mathrm{mm}$, ápice truncado, emarginado, margem inteira. Ginostêmio ca. 4 mm compr., base projetada em pé de ca. $3 \mathrm{~mm}$ compr.; grãos de pólen aglutinados em polínias. Polínias 4, em dois pares subiguais, maciças, providas de estipe e viscídio. Ovário + pedicelo 11-13 mm compr. Fruto não visto.

Material examinado: Sine loco, 29.I.1921, fl., F.C. Hoehne (SP).

Koellensteinia eburnea é conhecida para a Bolívia e a região central do Brasil, nos estados de Goiás, Mato Grosso, Mato Grosso do Sul e Minas Gerais, além do Distrito Federal (BFG 2015; Govaerts et al. 2015). Na etiqueta do material analisado não é referido o habitat em que foi encontrada na SOB, mas de acordo com o que se conhece sobre a espécie, é provável que ocorra em margens de cursos d'água, como saxícola ou terrícola, em vegetação aberta. Foi encontrada florida em janeiro. Pode ser reconhecida por suas folhas plicadas, dispostas no ápice do pseudobulbo, com base longamente atenuada, a inflorescência lateral, laxa, portando flores alvas com máculas lilases e o labelo com calo transversal e bilobado na base.

\section{Liparis Rich.}

Ervas terrícolas. Crescimento simpodial. Raízes filiformes, cobertas por velame. Rizoma geralmente inconspícuo. Cauloma intumescido em pseudobulbo, homoblástico, ovoide a obclavado,

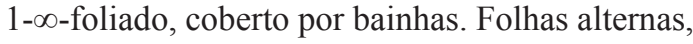
espiraladas, amplexicaules, membranáceas, predominantemente verdes, elíptico-lanceoladas a obovadas. Inflorescência terminal, em racemo, multiflora. Flores pediceladas, ressupinadas, ecalcaradas, verde-amareladas a vináceas, membranáceas; sépalas livres entre si, a dorsal 
normalmente revoluta, as laterais podem apresentar-se torcidas; pétalas livres, mais estreitas que as sépalas, geralmente revolutas; labelo inteiro, livre, calosidade, quando presente, constituída por um calo bífido na base do labelo. Ginostêmio claviforme, encurvado; antera apical, versátil; grãos de pólen aglutinados em polínias. Polínias 4, nuas.

\section{Chave de identificação para espécies de Liparis ocorrentes na Serra do Ouro Branco}

1. Plantas vegetando em ambiente sombreado, no interior de matas; cauloma ca. 4-foliado; folha plicada; labelo obcordado, fortemente reflexo, ápice emarginado 1. Liparis nervosa

1'. Plantas vegetando em ambientes abertos, em formações campestres; cauloma 1-foliado; folhas planas, inflexas; labelo largo-elíptico, subpatente, ápice apiculado 2. Liparis lindeniana

23.1. Liparis nervosa (Thunb.) Lindl., Gen. Sp. Orchid. Pl.: 26. 1830.

Fig. 8a

Terrícola, ca. $43 \mathrm{~cm}$ alt. Pseudobulbo obclavado, ca. $7 \mathrm{~cm}$ compr., ca. 4-foliado. Folhas alternas, espiraladas, subpatentes, plicadas, membranáceas, verdes, obovadas, $15-25,5 \times$ 4-8,2 cm, base atenuada, amplexicaule, ápice acuminado. Inflorescência terminal, em racemo, laxa, ca. 18-flora; pedúnculo ca. $19 \mathrm{~cm}$ compr.; brácteas do pedúnculo patentes, lanceoladas, ca. $10 \times 2,5 \mathrm{~mm}$, ápice agudo; raque ca. $16 \mathrm{~cm}$ compr.; brácteas florais lanceoladas a estreitotriangulares, 6-10 × 1,5-2,5 mm, ápice agudo. Flores variando entre vináceo e verde; sépala dorsal oblonga, revoluta, $8-9 \times 2-3 \mathrm{~mm}$, ápice obtuso a arredondado; sépalas laterais elípticofalcadas, torcidas, 6,5-7 $\times 3-3,5 \mathrm{~mm}$, ápice obtuso a arredondado; pétalas oblongas a oblongooblanceoladas, revolutas, falcadas, 7-8,5 × 1,5-2 $\mathrm{mm}$, ápice obtuso a arredondado; labelo inteiro, obcordado, fortemente reflexo, 7-8 $\times 6-6,5 \mathrm{~mm}$, ápice emarginado, margem inteira a levemente denteada; calosidade bífida, na base. Ginostêmio ca. $5 \mathrm{~mm}$ compr. Ovário + pedicelo $1-1,5 \mathrm{~cm}$ compr. Fruto fusiforme-clavado, ca. $2 \times 0,8 \mathrm{~cm}$. Material examinado: Mata do Argrives (terreno da Vale do Rio Doce), 6.XII.2013, fl. e fr., T.L. Vieira 169 (SP).

Liparis nervosa é amplamente distribuída, ocorrendo desde o Japão, Sudeste Asiático, África até as Américas Central e do Sul, principalmente na região tropical, com ampla distribuição pelo Brasil (BFG 2015; Govaerts et al. 2015). Na SOB foi coletada como terrícola em Floresta Estacional Semidecidual, florida em dezembro. Pode ser reconhecida pelas folhas bem desenvolvidas, membranáceas e plicadas, bem como pelo fato de apresentar flores predominantemente vináceas, com labelo obcordado, reflexo e de ápice emarginado.
23.2. Liparis lindeniana (A.Rich. \& Galeotti) Hemsl., Gard. Chron., n.s., 11: 559. 1879.

Fig. $8 \mathrm{~b}$

Terrícola, $13-15 \mathrm{~cm}$ alt. Pseudobulbo ovoide, 1-1,5 cm compr., coberto por bainhas, 1 -foliado no ápice. Folhas suberetas, espatiformes, inflexas, planas, membranáceas, verdes, elípticolanceoladas, ca. $8,5 \times 2,2 \mathrm{~cm}$, base amplexicaule, ápice agudo. Inflorescência terminal, em racemo, sublaxa, 10-15-flora; pedúnculo 4,7-8 cm compr., desprovido de brácteas; raque 4,5-7,5 cm compr.; brácteas florais lanceoladas, $5-7 \times 2-3 \mathrm{~mm}$, ápice agudo. Flores amarelo-esverdeadas; sépala dorsal oblongo-lanceolada, revoluta, 7,5 × 2-2,5 $\mathrm{mm}$, ápice agudo; sépalas laterais lanceoladofalcadas, 6-7 × 2,5-3 mm, ápice agudo; pétalas lineares, revolutas, ligeiramente falcadas, ca. $7 \times$ $1 \mathrm{~mm}$, ápice obtuso; labelo inteiro, largo-elíptico, subpatente, 6,5-8 × 5,5-6 mm, ápice apiculado, margem inteira. Ginostêmio ca. $4 \mathrm{~mm}$ compr. Ovário + pedicelo $0,9-1 \mathrm{~cm}$ compr. Fruto não visto.

Material examinado: cerca de $10,6 \mathrm{~km}$ do entroncamento com a MG-443, 5.III.2008, fl., J.A.N. Batista 2624 (BHCB); Lajeado, 14.II.2009, fl., G.E. Valente \& A.A. Azevedo 2443 (VIC, SP).

Liparis lindeniana distribui-se desde o México, passando pela América Central, até a América do Sul (Govaerts et al. 2015). No Brasil possui registros para os estados da Bahia, Goiás, Mato Grosso, Minas Gerais, São Paulo, Sergipe, Tocantins e da Região Sul, além do Distrito Federal (BFG 2015). Na SOB foi coletada como terrícola em campo limpo encharcado. Floresce entre fevereiro e março. Diferencia-se de L. nervosa pelo habitat, presença de apenas uma folha desenvolvida no cauloma, além da morfologia do labelo, que é largo-elíptico (vs. obcordado), subpatente (vs. reflexo) e com ápice apiculado (vs. emarginado). 

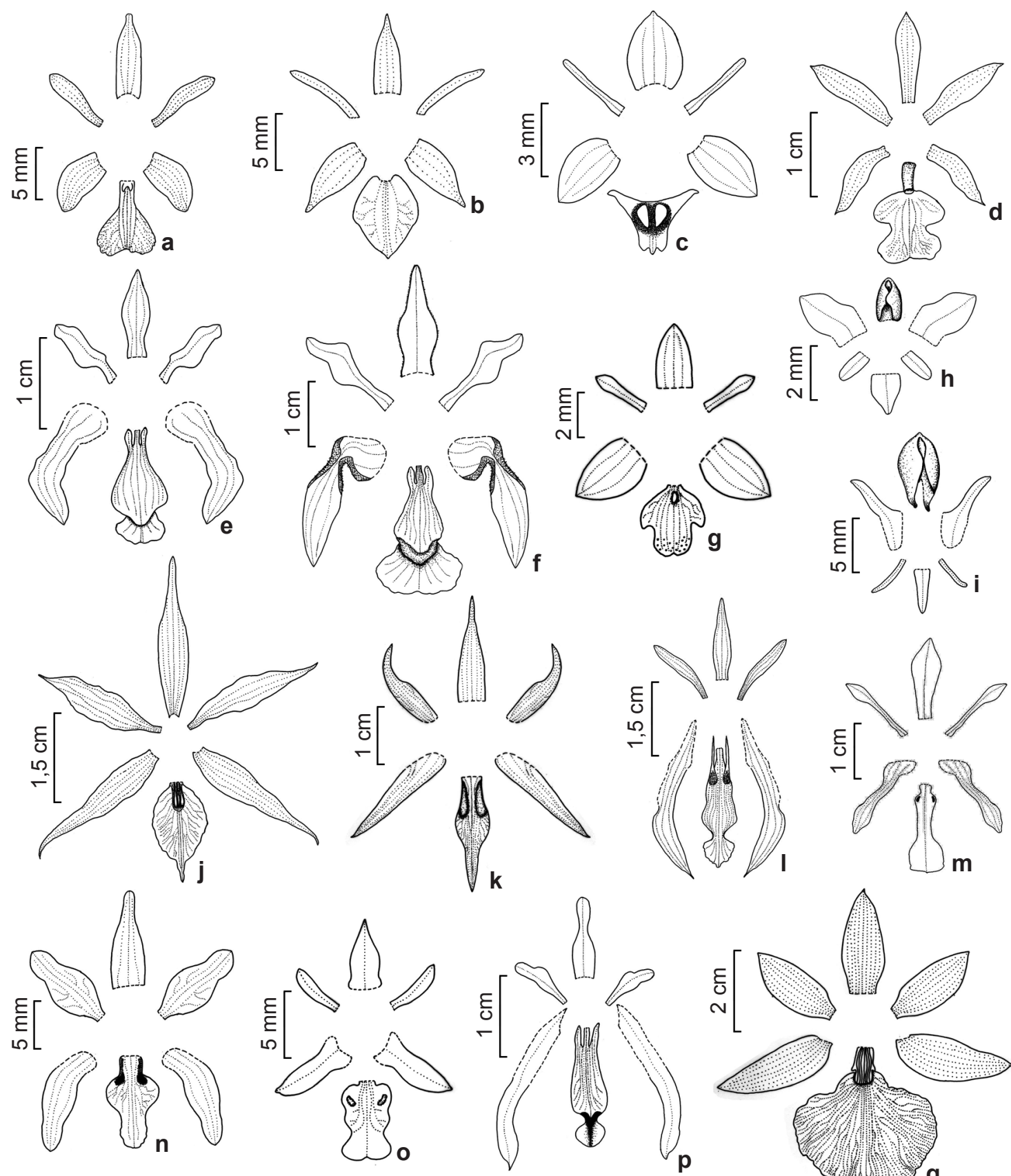

Figura 8 - Periantos dissecados. a. Liparis nervosa (Vieira 169). b. Liparis lindeniana (Valente \& Azevedo 2443). c. Malaxis excavata (Vieira 207). d. Oeceoclades maculata (Vieira 258). e. Pelexia orobanchoides (Souza \& Sakugari 2025). f. Pelexia orthosepala (Batista 2606). g. Polystachya estrellensis (Vieira 178). h. Prescottia oligantha (de Paula et al. 174). i. Prescottia stachyodes (Vieira 153). j. Prosthechea bulbosa (Badini s/n). k. Sacoila lanceolate (Vieira 135). 1. Sarcoglottis fasciculata (Vieira 202). m. Sauroglossum elatum (Braga s/ $n$ ). n. Skeptrostachys balanophorostachya (Valente 1731). o. Stigmatosema polyaden (Vieira 247). p. Veyretia rupicola (de Paula et al. 311). q. Zygopetalum maculatum (Mello Barreto 4896).

Figure 8 -Dissected perianths. a. Liparis nervosa (Vieira 169). b. Liparis lindeniana (Valente \& Azevedo 2443). c. Malaxis excavata (Vieira 207). d. Oeceoclades maculata (Vieira 258). e. Pelexia orobanchoides (Souza \& Sakugari 2025). f. Pelexia orthosepala (Batista 2606). g. Polystachya estrellensis (Vieira 178). h. Prescottia oligantha (de Paula et al. 174). i. Prescottia stachyodes (Vieira 153). j. Prosthechea bulbosa (Badini s/ $n$ ). k. Sacoila lanceolate (Vieira 135). 1. Sarcoglottis fasciculata (Vieira 202).m. Sauroglossum elatum (Braga s/n).n. Skeptrostachys balanophorostachya (Valente 1731). o. Stigmatosema polyaden (Vieira 247). p. Veyretia rupicola (de Paula et al. 311). q. Zygopetalum maculatum (Mello Barreto 4896). 
Originalmente, Cougniaux, na Flora Brasiliensis, reconheceu duas espécies unifoliadas de Liparis: L. campestris Barb.Rodr. e L. vexillifera (Lex.) Cogn., a primeira sendo referida para regiões montanhosas de Minas Gerais e também São Paulo, e a segunda aplamente distribuída pela região neotropical, com provável ocorrência no Brasil. Posteriormente, Pabst \& Dungs (1975) propuseram a sinonímia de $L$. campestris Barb.Rodr. sob $L$. vexillifera, o que acarretou na ampla aplicação deste último nome às Liparis unifolioladas coletadas no Brasil. Recentemente, foi elucidado que, na realidade, $L$. vexillifera é uma espécie restrita ao Mexico e América Central (Goaverts et al. 2015), tratando-se de plantas maiores e distintas na realidade, o que tornaria $L$. campestris o nome mais adequado a ser aplicado às plantas brasileiras (Batista com. pes.). Todavia, L. campestris atualmente é reconhecida como um sinônimo de L. lindeniana (Govaerts et al. 2015).

24. Malaxis Sol. ex Sw.

24.1. Malaxis excavata (Lindl.) Kuntze, Revis. Gen. Pl. 2: 673. 1891.

Fig. 8c

Terrícola, humícola, 23,5-26 cm alt. Crescimento simpodial. Raízes filiformes, cobertas por velame. Rizoma geralmente inconspícuo, quando conspícuo ca. $2 \mathrm{~cm}$ compr. Cauloma intumescido em pseudobulbo. Pseudobulbo homoblástico, ovoide, 3-4 cm compr., coberto por bainhas, 2-foliado. Folhas alternas, espiraladas, patentes a subpatentes, planas, membranáceas, verdes, lustrosas, ovadas, 9-10,5 × 4,2-5,4 cm, base amplexicaule, ápice agudo a acuminado. Inflorescência terminal, em corimbo, congesta, multiflora; pedúnculo 19-20 cm compr., desprovido de brácteas; raque 3-6 mm compr., brácteas florais deltoides, ca. $1 \times 1 \mathrm{~mm}$, ápice agudo. Flores verdes, não ressupinadas, pediceladas, ecalcaradas; sépala dorsal ovada, 3-3,5 × 1,5-2,5 mm, ápice apiculado; sépalas laterais ovadas, $3 \times 1,5-2 \mathrm{~mm}$, ápice obtuso; pétalas lineares, 2,5-3 $30,5 \mathrm{~mm}$, ápice arredondado; labelo inteiro, largo-triangular, 2,5-3 × 3-4 mm, ápice tridentado, margem inteira. Ginostêmio ca. $1 \mathrm{~mm}$ compr; antera dorsal; grãos de pólen aglutinados em polínias. Polínias 4, maciças, nuas. Ovário + pedicelo 1-1,2 cm compr. Fruto fusiforme, ca. $1 \times 0,6 \mathrm{~cm}$.

Material examinado: área 2, 8.XII.2002, fl. e fr., C.C. de Paula et al. 529 (VIC); porção oeste da serra, depois das antenas, 25.VI.2014, fl. cult. IX.2014, T.L. Vieira 207 (SP).

Malaxis excavata apresenta ampla distribuição na região Neotropical, desde o México até o norte da
Argentina (Govaerts et al. 2015). No Brasil, possui registros para os estados da Bahia, Pernambuco e das regiões Sudeste e Sul, além do Distrito Federal (BFG 2015). Na SOB foi encontrada em matas de galeria e capões de mata, como terrícola em locais com acúmulo de serapilheira. Floresceu em ambiente natural e cultivo, respectivamente em dezembro e setembro. É facilmente reconhecível pelo seguinte conjunto de caracteres: um par de folhas verdes, lustrosas, membranáceas, inflorescência bastante congesta, em corimbo, e flores verdes não ressupinadas, com ápice do labelo tridentado.

\section{Oeceoclades Lindl.}

25.1. Oeceoclades maculata (Lindl.) Lindl., Gen. Sp. Orchid. Pl.: 237. 1833.

Fig. 8d

Terrícola, ca. $30 \mathrm{~cm}$ alt. incluindo a inflorescência Crescimento simpodial. Raízes filiformes, cobertas por velame. Rizoma inconspícuo. Cauloma intumescido em pseudobulbo. Pseudobulbo heteroblástico, ovoide, ca. 2,3 cm compr., 1-foliado. Folha no ápice do pseudobulbo, ereta a subereta, coríácea, verde, variegada, elíptica, 10,5-17 × 2,7-2,8 cm, séssil, ápice agudo a apiculado. Inflorescência lateral, em racemo, podendo, ocasionalmente, apresentar ramificações, laxa, pauciflora; pedúnculo ca. $22 \mathrm{~cm}$ compr.; brácteas do pedúnculo amplectivas, eretas, lanceoladas, 1,9-2,5 × 0,4-0,6 cm, ápice agudo; raque ca. $6 \mathrm{~cm}$ compr.; brácteas florais triangulares, 2-9 × 1-2 mm, ápice agudo. Flores ressupinadas, pediceladas, calcaradas; calcar formado pela base do labelo, clavado, ca. $4 \mathrm{~cm}$ compr.; sépala dorsal creme-esverdeada, oblanceolada, ca. $11 \times 3 \mathrm{~mm}$, ápice agudo; sépalas laterais creme-esverdeadas, livres, falcado-oblanceoladas, ca. $10 \times 2 \mathrm{~mm}$, ápice agudo; pétalas creme-esverdeadas, estreitoelípticas, ca. $12 \times 3 \mathrm{~mm}$, ápice agudo; labelo alvo, maculado de vináceo, trilobado, âmbito subquadrado, ca. $9 \times 9 \mathrm{~mm}$, com calo bífido na base, base prolongada formando o calcar, lobos laterais hemielípticos, ca. $3 \times 4 \mathrm{~mm}$, ápice arredondado, margem inteira, lobo mediano transversalmente elíptico, ca. $3,5 \times 8 \mathrm{~mm}$, ápice emarginado a truncado, margem minutamente erosa. Ginostêmio ca. $4 \mathrm{~mm}$ compr., base projetada em pé, ca. $1,5 \mathrm{~mm}$ compr; antera apical, incumbente, versátil; grãos de pólen aglutinados em polínias. Polínias 2, maciças, providas de estipe e viscídio. Ovário + pedicelo ca. $1,4 \mathrm{~cm}$ compr. Fruto não visto.

Material examinado: Mata do Argrives (área da Vale do Rio Doce), 6.XII.2013, fl. cult. II.2014, T.L. Vieira 258 (SP). 
Oeceoclades maculata faz parte de um gênero originalmente africado e é a única espécie que ocorre nas regiões tropical e subtropical do Novo Mundo, de modo subespontâneo, desde a Flórida até a Argentina (Govaerts et al. 2015). No Brasil ocorre em praticamente todos os estados, não apresentando registro apenas para o Amapá (BFG 2015). Trata-se de uma espécie comumente encontrada em florestas secundárias ou em estado inicial de regeneração e, eventualmente, até em áreas com vegetação bastante antropizada. $\mathrm{Na}$ SOB foi encontrada em matas de galeria e Floresta Estacional Semidecidual. Floresceu em cultivo, em fevereiro. Espécie de fácil identificação pelas folhas verdes variegadas, inflorescência pauciflora e flores com labelo alvo maculado de vináceo com base projetada em calcar.

26. Pelexia Poit. ex Lindl.

Ervas terrícolas. Crescimento simpodial. Raízes tuberiformes. Rizoma inconspícuo. Caule inconspícuo até curto, não intumescido em pseudobulbo. Folhas alternas espiraladas, geralmente verdes, eventualmente maculadas, membranáceas, pecioladas, frequentemente ausentes durante a antese. Inflorescência terminal, em racemo, geralmente pauciflora. Flores pediceladas, ressupinadas, ecalcaradas, alvoesverdeadas, membranáceas; externamente pilosas; sépala dorsal livre, as laterais adnatas ao pé da coluna, coalescentes entre si e infladas na base, formando mento saquiforme; pétalas livres entre si, aderidas à sépala dorsal; labelo unguiculado, dividido em hipoquílio e epiquílio, com par de aurículas digitiformes, retrorsas, na base, paralelas ao unguículo; par de glândulas nectaríferas pubescentes ausentes na base; hipoquílio com margens aderidas ao ginostêmio. Ginostêmio alongado, com pé de tamanho semelhante ao ginostêmio propriamente dito; rostelo maleável, laminar; antera dorsal, ereta; grãos de pólen aglutinados em polínias. Polínias 2, farinosas, providas apenas de viscídio. Zona de abscisão entre pedicelo e ovário ausente.

\section{Chave de identificação para espécies de Pelexia ocorrentes na Serra do Ouro Branco}

1. Plantas áfilas durante a floração; sépala dorsal ca. $11 \times 3 \mathrm{~mm}$; labelo $13-14 \times 7 \mathrm{~mm}$; hipoquílio mais largo que o epiquílio 1. Pelexia orobanchoides

1'. Plantas comumente apresentando folhas durante a floração, mesmo que em senescência; sépala dorsal ca. 15-18 × 5-7 mm; labelo 19-22 × 9-13 mm; hipoquílio mais estreito que o epiquílio

2. Pelexia orthosepala

26.1. Pelexia orobanchoides (Kraenzl.) Schltr., Beih. Bot. Centralbl. 37(2): 404. 1920. Fig. 8e Terrícola, 23-27 cm alt. Folhas não vistas, ausentes durante a floração. Inflorescência subcongesta, esparsamente pilosa, 7-12-flora; pedúnculo 15,5-18 cm compr.; brácteas do pedúnculo amplectivas, laxas, eretas, lanceoladas, $2-4 \times 0,3-1 \mathrm{~cm}$, ápice agudo; raque $3-9 \mathrm{~cm}$ compr.; brácteas florais lanceoladas, $1-2,3 \times$ $0,2-0,5 \mathrm{~cm}$, ápice agudo. Flores alvo-esverdeadas, externamente esparso-pilosas; sépala dorsal lanceolada com constrição abaixo da porção mediana, ca. $11 \times 3 \mathrm{~mm}$, ápice acuminado; sépalas laterais oblongo-oblanceoladas, falcadas, 14-16 × 3-4 mm, ápice obtuso; pétalas oblanceoladas, sinuoso-falcadas, ca. $10 \times 2,5 \mathrm{~mm}$, ápice obtuso; labelo unguiculado, dividido em hipoquílio e epiquílio, âmbito oblongo-obovado, 13-14 × $7 \mathrm{~mm}$, par de aurículas digitiformes na base do labelo, paralelas ao unguículo; hipoquílio obovado, $10 \times$ 6,5-7 mm, margens inteiras, região apical projetada sobre o epiquílio sem formar calosidade; epiquílio unguiculado, transversalmente elíptico, ca. 3-4 × 5-6 mm, ápice levemente emarginado a truncado, margem levemente ondulada. Ginostêmio 5-6 mm compr., base projetada em pé de 7-8 $\mathrm{mm}$ compr. Ovário + pedicelo ca. 1,3 cm compr., pilosos. Fruto não visto.

Material examinado: cerca de $10 \mathrm{~km}$ da cidade, 11.X.1992, fl., V.C. Souza \& C.M. Sakuragui 2025 (ESA); Sine loco, 28.IX.2012, f1., M. Sobral et al. 14998 (HUFSJ).

Pelexia orobanchoides é conhecida para a Colômbia e o Brasil, onde foi registrada nos estados da Bahia, Minas Gerais, Paraná e São Paulo, principalmente em campos limpos, de altitude e rupestres (BFG 2015; Govaerts et al. 2015). Na SOB foi coletada em campo limpo com solo arenoso. Floresce em outubro. Diferencia-se da outra espécie do gênero na SOB pelo hipoquílio mais largo que o epiquílio, com porção apical projetando-se sutilmente sobre o epiquílio, enquanto 
em $P$. orthosepla essa projeção se dá através de uma calosidade formada por carenas confluentes, salientes e carnosas, muito marcadas e evidentes.

26.2. Pelexia orthosepala (Rchb.f. \& Warm.) Schltr., Beih. Bot. Centralbl. 37(2): 404. 1920.

Fig. $8 \mathrm{f}$

Terrícola, $27,5-50 \mathrm{~cm}$ alt. Caule inconspícuo a até ca. $5 \mathrm{~cm}$ compr. Folhas, quando presentes durante a floração, em um par apenas, alternas, imbricadas, suberetas, geralmente apresentandose senescentes, membranáceas, verdes, podendo apresentar listras longitudinais alvas, oblanceoladas a estreito-elípticas, $10,5-15,5 \times 1,3-2,5 \mathrm{~cm}$, base atenuada, amplexicaule, ápice agudo. Inflorescência sublaxa, pilosa, 3-11-flora, pedúnculo 19-33 cm compr.; brácteas do pedúnculo amplectivas, laxas, eretas, oblanceoladas a estreito-elípticas próximo à base do pedúnculo, tornando-se lanceoladas em direção ao ápice, 2,7-12 × 0,5-1,2 cm, ápice agudo a acuminado; raque $2-7,5 \mathrm{~cm}$ compr.; brácteas florais lanceoladas, 1,5-2,5 × 0,2-0,5 $\mathrm{cm}$, ápice longamente acuminado. Flores alvoesverdeadas, externamente denso-pilosas; sépala dorsal lanceolada a ovada, com constrição abaixo da porção mediana, $15-18 \times 5-7 \mathrm{~mm}$, ápice acuminado; sépalas laterais oblanceoladas a elípticas, falcadas, 19-22 × 5-6 mm, ápice obtuso; pétalas oblanceoladas, sinuoso-falcadas, 15-18 × 5-6 mm, ápice obtuso; labelo de âmbito oblongo-obovado, 19-22 ×9-13 mm; hipoquílio obovado, 13-15 × 7-9 mm, margens inteiras, região apical com calosidade carnosa e elevada em forma de "v" que se projeta sobre o epiquílio; epiquílio unguiculado, depressamente obovado a trasnversalmente elíptico, 6-7 × 9-13 mm, ápice levemente emarginado a truncado, margem ondulada. Ginostêmio 8-11 mm compr., base projetada em pé de 6-9 mm compr. Ovário + pedicelo 1-1,6 cm compr., densamente pilosos. Fruto não visto.

Material examinado: estrada entre Ouro Branco e o Morro do Gabriel, ca. 9 km de Ouro Branco, 8.III.1995, fl., V.C. Souza et al. 7946 (ESA); Estrada Ouro Branco - Ouro Preto, ca. $6 \mathrm{~km}$ de Ouro Branco, estrada para o Morro do Gabriel, 9.III.1995, fl., V.C. Souza 8093 (ESA, SP); Área 2, 28.II.2003, fl., C.C. de Paula et al. 698 (VIC); próximo às antenas da Embratel, 26.III.2004, fl., G.E. Valente et al. 1489 (VIC); trecho inicial da serra, próximo ao entroncamento com a MG-443, 5.III.2008, fl., J.A.N. Batista 2606 (BHCB); Sine loco, 11.III.2008, fl., G.E. Valente et al. 2032 (VIC, SP).

Pelexia orthosepala é endêmica do Brasil, com distribuição conhecida para os estados da Bahia, Espírito Santo e Minas Gerais, além do Distrito Federal (BFG 2015). Na SOB foi encontrada em campo rupestre e campo limpo, florescendo em março. Quando comparada a $P$. orobanchoides, pode ser diferenciada pelo porte mais robusto, presença eventual de folhas durante a floração ( $v s$. planta sempre áfila durante a floração), bem como pelas flores maiores (labelo de 19-22 $\mathrm{mm}$ compr. vs. 13-14 mm compr.). Além disso, em $P$. orthosepala o epiquílio é mais largo que o hipoquílio, enquanto em $P$. orobanchoides essa relação se inverte.

\section{Polystachya Hook.}

27.1. Polystachya estrellensis Rchb.f., Linnaea 25: 231. 1852.

Fig. $8 \mathrm{~g}$

Epífita, 15-27 cm alt incluindo a inflorescência. Crescimento simpodial. Raízes filiformes, cobertas por velame. Rizoma inconspícuo. Cauloma intumescido em pseudobulbo. Pseudobulbo homoblástico, globoso a ovoide, $1-1,5 \mathrm{~cm}$ compr., 2-5-foliado. Folhas alternas, dísticas, subpatentes, conduplicadas, coríaceas, verdes, estreito-elípticas, $1,7-11,5 \times 0,7-2 \mathrm{~cm}$, base amplexicaule, ápice agudo. Inflorescência terminal, em racemo ou panícula, laxa, multiflora; pedúnculo 4-10 cm compr.; brácteas do pedúnculo escariosas, amplectivas, adpressas, oblongas, 1,3-6,7 × 0,3$0,7 \mathrm{~cm}$, ápice agudo; raque $8,5-12,5 \mathrm{~cm}$ compr.; brácteas florais triangulares, $1-3 \times 2-3 \mathrm{~mm}$, ápice agudo. Flores alvo-esverdeadas, não ressupinadas, pediceladas, ecalcaradas; sépala dorsal ovada a largo-ovada, 2-3 $32 \mathrm{~mm}$, ápice obtuso; sépalas laterais adnatas, na base, ao pé da coluna, formando um mento, largo-ovadas a subdeltoides, 2,5-3 × 2-3 $\mathrm{mm}$, ápice obtuso; pétalas oblongo-oblanceoladas, 2,5-3 $\times 1 \mathrm{~mm}$, ápice arredondado a obtuso; labelo trilobado, âmbito depressamente ovado, 3,5 × 3-3,5 $\mathrm{mm}$, com calo na base, lobos laterais curto-ovados, $1 \times 1-2 \mathrm{~mm}$, ápice arredondado ou obtuso, margem inteira, lobo mediano transversalmente oblongo, $1,5 \times 2-2,5 \mathrm{~mm}$, ápice emarginado ou arredondado, margem inteira. Ginostêmio ca. 1,5 mm compr., base em pé, ca. $1 \mathrm{~mm}$ compr.; antera apical, incumbente, versátil; grãos de pólen aglutinados em polínias. Polínias 2, maciças, providas de estipe e viscídio. Ovário + pedicelo 3-4 mm compr. Fruto fusiforme, 6-11×2-3 $\mathrm{mm}$.

Material examinado: Sine loco, 5.XII.2013, fl., T.L. Vieira 168 (SP); 24.I.2014, fl. e fr. cult. III.2014, T.L. Vieira 178 (SP).

Polystachya estrellensis é endêmica do Brasil, com ampla distribuição no país, ocorrendo 
em quase todos os estados (BFG 2015). Na SOB foi encontrada ao sopé da serra em capão de mata, mata de galeria e Floresta Estacional Semidecidual. Floresce entre dezembro e março. Pode ser diferenciada das demais espécies da SOB pelas flores diminutas, alvo-esverdeadas, não ressupinadas, dispostas em racemos ou panículas. O labelo geralmente apresenta, na superfície adaxial, um acúmulo de pequenos grânulos, denominados pseudopólen (Pansarin \& Amaral 2006), coletados por abelhas nativas como recompensa.

\section{Prescottia Lindl.}

Ervas terrícolas. Crescimento simpodial. Raízes tuberiformes. Rizoma ausente. Caule inconspícuo, não intumescido em pseudobulbo.
Folhas alternas, espiraladas, comumente rosuladas, em variados tons de verde, ocasionalmente variegadas, membranáceas a coriáceas, sésseis até longamente pecioladas. Inflorescência terminal, em espiga, geralmente multiflora. Flores sésseis, não ressupinadas, ecalcaradas, alvas a esverdeadas, membranáceas; sépalas geralmente reflexas, a dorsal livre, as laterais coalescentes entre si na base, geralmente formando um pequeno, e pouco evidente, mento; pétalas livres entre si, geralmente reflexas; labelo inteiro, curtamente unguiculado, elmiforme, interior glabro ou piloso, com par de glândulas nectaríferas na base. Ginostêmio curto, cilíndrico; antera dorsal, ereta; grãos de pólen aglutinados em polínias. Zona de abscisão entre pedicelo e ovário ausente. Polínias 4, macias, providas apenas de viscídio.

\section{Chave de identificação para espécies de Prescottia ocorrentes na Serra do Ouro Branco}

1. Plantas com ca. $15 \mathrm{~cm}$ alt.; folhas sésseis; flores alvas; labelo ca. 1,5 $\times 1 \mathrm{~mm}$, internamente piloso .... 1. Prescottia oligantha

1'. Plantas com 98-120 cm alt.; folhas com pecíolo de 11-26 cm compr.; flores verdes a verde-acastanhadas; labelo ca. $7 \times 4 \mathrm{~mm}$, internamente glabro 2. Prescottia stachyodes

28.1. Prescottia oligantha (Sw.) Lindl., Gen. Sp. Orchid. Pl.: 454. 1840.

Fig. 8h

Terrícola, ca. $15 \mathrm{~cm}$ alt. Folhas patentes, membranáceas, verdes, ovadas, $1,8-2,1 \times 0,8-1 \mathrm{~cm}$, sésseis, ápice agudo. Inflorescência subcongesta a congesta, pedúnculo ca. $12 \mathrm{~cm}$ compr.; brácteas do pedúnculo amplectivas, eretas, estreito-elípticas a lanceoladas, 5-14 × 1-2,5 mm, ápice agudo a acuminado; raque 3-3,2 cm compr.; brácteas florais lanceoladas a ovadas, $2-3 \times 1 \mathrm{~cm}$, ápice longamente acuminado. Flores alvas; sépala dorsal ovada, ca. $1,5 \times 1 \mathrm{~mm}$, ápice obtuso; sépalas laterais ovadas, 2,5 × 1-1,5 mm, ápice obtuso; pétalas oblongas, $1,5 \times 0,5 \mathrm{~mm}$, ápice arredondado; labelo ca. 1,5 $\times 1 \mathrm{~mm}$, superfície interna pilosa, ápice obtuso, margem inteira. Ginostêmio ca. $1 \mathrm{~mm}$ compr. Ovário 1,5-3,3 mm compr. Fruto não visto.

Material examinado: Área 2, 13.VII.2002, fl., C.C. de Paula et al. 174 (VIC).

Prescottia oligantha é amplamente distribuída na região neotropical, desde o sul da Flórida até a Argentina (Govaerts et al. 2015). No Brasil ocorre nos estados do Alagoas, Bahia, Goiás, Mato Grosso do Sul, Pernambuco, Roraima, das regiões Sudeste e Sul, além do Distrito Federal (BFG 2015). Na SOB foi encontrada em campo rupestre, como terrícola em áreas parcialmente sombreadas entre afloramentos rochosos. Floresce em julho. Pode ser reconhecida pelo hábito terrícola, tamanho reduzido (ca. $15 \mathrm{~cm}$ alt), com folhas pequenas e patentes, flores alvas e muito pequenas (labelo ca. $1,5 \times 1 \mathrm{~mm}$ ). Distingue-se de $P$. stachyodes pelo porte menor (altura, tamanho de folhas, inflorescência e flores), bem como pelas flores alvas (vs. verdes).

28.2. Prescottia stachyodes (Sw.) Lindl., Edwards's Bot. Reg. 22, t. 1915. 1836. Fig. $8 \mathrm{i}$

Terrícola, $98-120 \mathrm{~cm}$ alt. Folhas suberetas, coriáceas, verdes, lâmina ovada a elíptica, $14-21 \times 5,5-7,8 \mathrm{~cm}$, pecíolo de 11-26 cm compr., ápice agudo a obtuso. Inflorescência laxa na base, tornando-se congesta em direção ao ápice; pedúnculo 70-92 cm compr.; brácteas do pedúnculo amplectivas, eretas, estreito-elípticas a oblanceoladas, 4-10,8 $\times 1-1,5 \mathrm{~cm}$, ápice agudo a acuminado; raque 25-27,5 cm compr.; brácteas florais lanceoladas a ovadas, 5-12 × 2-3 mm, ápice longamente acuminado. Flores verdes a verdeacastanhadas; sépala dorsal lanceolada, ca. $4 \times 1$ $\mathrm{mm}$, ápice obtuso; sépalas laterais lanceoladas, levemente falcadas, 7,5 × $1 \mathrm{~mm}$, ápice obtuso; pétalas oblongas, $3,8 \times 0,5 \mathrm{~mm}$, ápice obtuso; labelo ca. $7 \times 4 \mathrm{~mm}$, superfície interna glabra, 
ápice obtuso, margem inteira. Ginostêmio ca. $2 \mathrm{~mm}$ compr. Ovário 4-11 mm compr. Fruto não visto. Material examinado: Área 2, 23.IX.2002, fl., C.C. de Paula et al. 338 (VIC); 14.IX.2013, fl. cult. VII.2014, T.L. Vieira et al. 153 (SP); imediações do Morro do Gabriel, 14.IX.2013, fl. cult. IX.2014, T.L. Vieira et al. 157 (SP).

Prescottia stachyodes é amplamente distribuída na região neotropical, desde o México até a Argentina (Govaerts et al. 2015). No Brasil, é conhecida para os estados de Alagoas, Amazonas, Bahia, Ceará, Goiás, Pará, Paraíba, Pernambuco, das regiões Sudeste e Sul, além do Distrito Federal (BFG 2015). Na SOB ocorre ao sopé da serra, no interior de matas de galeria e Floresta Estacional Semidecidual. Floresce entre julho e setembro. Pode ser facilmente reconhecida pelas folhas geralmente bem desenvolvidas, com longos pecíolos, inflorescência também longa, com raque de 25-27,5 cm compr. e flores verdes a verdeacastanhadas.

\section{Prosthechea Knowles \& Westc.}

29.1. Prosthechea bulbosa (Vell.) W.E.Higgins, Phytologia 82(5): 377. $1998 . \quad$ Fig. 8j

Epífita, ca. $34 \mathrm{~cm}$ alt. Crescimento simpodial. Raízes não vistas. Rizoma não visto. Cauloma intumescido em pseudobulbo. Pseudobulbo heteroblástico, obclavado ca. $10 \mathrm{~cm}$ compr., 2 -foliado. Folhas no ápice do pseudobulbo, suberetas, planas, coriáceas, verdes, oblongoelípticas, 24-24,5 × 2,4 cm, sésseis, ápice obtuso. Inflorescência terminal, em racemo, sublaxa, multiflora; pedúnculo ca. $6 \mathrm{~cm}$ compr., espata ca. $6,3 \mathrm{~cm}$ compr.; raque ca. $6 \mathrm{~cm}$ compr., brácteas florais triangulares, 3-6 × 2-3,5 mm, ápice agudo a acuminado. Flores alvas, não ressupinadas, pediceladas; sépala dorsal lanceolada, ca. $2,7 \times 0,5$ $\mathrm{cm}$, ápice acuminado; sépalas laterais lanceoladas, ca. 2,7 ×0,5 cm, ápice acuminado; pétalas estreitoelípticas, $2,5 \times 0,5-0,6 \mathrm{~cm}$, ápice acuminado; labelo alvo com máculas lilases, inteiro, adnato ao ginostêmio até ca. 1/2 do comprimento deste, ovado, 1,7-1,8 ×0,9 cm, ápice acuminado, margem levemente ondulada; calo inteiriço na base do labelo, estendendo-se em três lamelas em direção ao ápice do labelo. Ginostêmio 8-10 mm compr; antera apical, incumbente, versátil; grãos de pólen aglutinados em polínias. Polínias 4 , providas apenas de caudículas. Ovário + pedicelo $1-1,2 \mathrm{~cm}$ compr. Fruto não visto.

Material examinado: Sine loco, 17.X.1941, fl., J. Badini (SP).

Prosthechea bulbosa distribui-se entre o leste e sul do Brasil, alcançando o Paraguai. No Brasil é conhecida para os estados da Bahia e das regiões Sudeste e Sul (BFG 2015; Govaerts et al. 2015). Não há indicação de habitat na etiqueta do exemplar analisado. Foi encontrada florida em outubro. Pode ser reconhecida por apresentar inflorescência terminal, pseudobulbo heteroblástico e bifoliado; flores não ressupinadas, alvas com máculas lilases, sépalas e pétalas estreitas com ápice acuminado, além do labelo inteiro com ápice acuminado.

\section{Sacoila Raf.}

30.1. Sacoila lanceolata (Aubl.) Garay, Bot. Mus. Leafl. 28(4): 352. $1982 . \quad$ Fig. 8k

Terrícola, 28-55 cmalt. Crescimento simpodial. Raízes tuberiformes. Rizoma inconspícuo. Caule não intumescido em pseudobulbo. Folhas não vistas, ausentes durante a floração. Inflorescência terminal, em racemo, subcongesta, pubescente, multiflora; pedúnculo 22,5-49 $\mathrm{cm}$ compr.; brácteas do pedúnculo amplectivas, eretas, estreito-elípticas a oblanceoladas, 2,7-4,8 $\times$ 0,5-1,1 cm, ápice agudo; raque 3,3-5,5 cm compr.; brácteas florais lanceoladas, 1-1,8 $\times$ $0,2-0,3 \mathrm{~cm}$, ápice longamente acuminado. Flores róseo-avermelhadas, externamente pubescentes, ressupinadas, pediceladas, ecalcaradas; sépala dorsal lanceolada, $1,3-1,9 \times 0,4-0,5 \mathrm{~cm}$, ápice acuminado; sépalas laterais adnatas ao pé da coluna, formando um mento, lanceoladas, 1,5-2,2 $\times 0,3-0,4 \mathrm{~cm}$, ápice agudo; pétalas aderidas à sépala dorsal, lanceoladas, falcadas, 1,2-1,5 × 0,3 $\mathrm{cm}$, ápice agudo; labelo unguiculado, dividido em hipoquílio e epiquílio, âmbito lanceolado, 1,6-2,1 $\times 0,5-0,6 \mathrm{~cm}$, par de calos alongados na base do labelo, próximo às margens; hipoquílio obovado, $10 \times 4,5-6 \mathrm{~mm}$, margens inteiras, aderidas ao ginostêmio; epiquílio triangular, 6-9 × 1,5-3 mm, ápice agudo, margem inteira. Ginostêmio 7-9 mm compr., base projetada em pé de 4-7 mm compr.; rostelo rígido, acicular; antera dorsal, ereta; grãos de pólen aglutinados em polínias. Polínias 2, farinosas, providas apenas de viscídio. Ovário + pedicelo 1-1,5 cm compr.; ovário piloso; zona de abscisão entre pedicelo e ovário ausente. Fruto não visto.

Material examinado: margem da rodovia MG-443, subindo a Serra do Ouro Branco (sentido Ouro Preto), 13.IX.2013, fl., T.L. Vieira et al. 135 (BHCB, SP, VIC); antenas, 13.IX.2013, fl., T.L. Vieira 136 (SP).

Sacoila lanceolata é amplamente distribuída em toda a região tropical e subtropical das Américas, desde a Flórida até a Argentina (Govaerts et al. 2015). No Brasil, não apresenta registros apenas para o Rio Grande do Norte, Rondônia e 
Roraima (BFG 2015). Na SOB foi encontrada em barranco na margem da rodovia que corta a serra e também em área antropizada nos arredores das antenas no topo da serra. Floresce em setembro. Características úteis no seu reconhecimento são o hábito terrícola, planta áfila durante a floração, inflorescência subcongesta, pubescente, e flores róseo-avermelhadas com aspecto tubular.

\section{Sarcoglottis C. Pres1}

31.1. Sarcoglottis fasciculata (Vell.) Schltr., Beih. Bot. Centralbl. 37(11): 415. $1920 . \quad$ Fig. 81

Terrícola, $20-40 \mathrm{~cm}$ alt. Crescimento simpodial. Raízes tuberiformes. Rizoma inconspícuo. Caule não intumescido em pseudobulbo, inconspícuo. Folhas rosuladas, sésseis, patentes a suberetas, pendentes quando suberetas, coriáceas, verdes, podendo apresentar-se variegadas, simétricas, obovadas a elípticas, 19-26,5 × 4,7-7,8 cm, base atenuada, ápice obtuso, eventualmente ausentes ou em estado de senescência durante a floração. Inflorescência terminal, em racemo, congesta, pilosa, 4-11-flora; pedúnculo 10-30 cm compr.; brácteas do pedúnculo amplectivas, laxas, eretas, elíptico-lanceoladas, $2-2,5 \times 0,5-0,7 \mathrm{~cm}$, ápice agudo; raque (1-) $10 \mathrm{~cm}$ compr.; brácteas florais elíptico-lanceoladas 2-2,2 $\times$ $0,4-0,6 \mathrm{~cm}$, ápice agudo. Flores alvo-acastanhadas, externamente pilosas, ressupinadas, pediceladas, ecalcaradas; sépala dorsal lanceolada, ca. $18 \times 4$ $\mathrm{mm}$, ápice agudo; sépalas laterais adnatas ao pé da coluna e coalescentes entre si na base, formando mento alongado, oblongo-lanceoladas, falcadas, ca. $32 \times 5 \mathrm{~mm}$, ápice agudo; pétalas aderidas à sépala dorsal, oblongo-oblanceoladas, levemente falcadas, ca. $16 \times 3 \mathrm{~mm}$, ápice agudo; labelo unguiculado, dividido em hipoquílio e epiquílio, âmbito oblongo, ca. $27 \times 7 \mathrm{~mm}$, par de glândulas nectaríferas pubescentes, próximas à base do labelo, que se projetam em aurículas digitiformes paralelas ao unguículo; hipoquílio oblanceolado, ca. $20 \times$ $7 \mathrm{~mm}$, margens inteiras, aderidas ao ginostêmio; epiquílio unguiculado, largo-ovado, ca. $6 \times 6,5$ $\mathrm{mm}$, ápice obtuso, margem levemente ondulada. Ginostêmio ca. $8 \mathrm{~mm}$ compr., base projetada em pé de ca. $16 \mathrm{~mm}$ compr.; rostelo maleável, laminar; antera dorsal, ereta; grãos de pólen aglutinados em polínias. Polínias 2, farinosas, providas apenas de viscídio. Ovário + pedicelo ca. $2 \mathrm{~cm}$ compr., piloso; zona de abscisão entre pedicelo e ovário ausente. Fruto não visto.

Material examinado: RPPN da Gerdau, 24.VI.2014, fl. cult. VIII.2014, T.L. Vieira 202 (SP); 24.VI.2014, fl. cult. VIII.2015, T.L. Vieira 273 (SP).
Sarcoglottis fasciculata é conhecida para o nordeste da Argentina e o leste do Brasil, nos estados da Bahia, Paraná, Pernambuco, Sergipe e da Região Sudeste (BFG 2015; Govaerts et al. 2015). Na SOB foi encontrada em Floresta Estacional Semidecidual, no sopé da porção sudoeste da serra. Floresceu em cultivo em agosto. Pode ser reconhecida por suas folhas rosuladas, variegadas, obovadas a elípticas, flores alvo-acastanhadas, além da presença de um par de glândulas nectaríferas pubescentes na base do labelo. O espécime analisado apresentou floração anômala, com inflorescência pouco desenvolvida, com número menor de flores e raque mais curta ao que é habitual para a espécie. Aparentemente, trata-se de estresse causado pela condição ex situ, uma vez que a floração se deu em cultivo, pouco tempo após o plantio.

\section{Sauroglossum Lindl.}

32.1. Sauroglossum elatum Lindl., Gen. Sp. Orchid. P1.: 480. 1830.

Fig. $8 \mathrm{~m}$

Terrícola, ca. $105 \mathrm{~cm}$ alt. Crescimento simpodial. Raízes tuberiformes. Rizoma inconspícuo. Caule inconspícuo, não intumescido em pseudobulbo. Folhas rosuladas, suberetas, membranáceas, verdes, oblanceoladas, 30-36 $\times 5,8-7,2 \mathrm{~cm}$, base longamente atenuada, ápice agudo. Inflorescência terminal, em racemo, subcongesta, pubescente, multiflora; pedúnculo ca. $70 \mathrm{~cm}$ compr.; brácteas do pedúnculo amplectivas, eretas, estreito-elípticas a lanceoladas, 2-9,5 $\times 0,4-1,8 \mathrm{~cm}$, ápice agudo; raque ca. $30 \mathrm{~cm}$ compr.; brácteas florais lanceoladas, 6-12 $\times$ 1,5-4 mm, ápice longamente acuminado. Flores alvo-esverdeadas, externamente pubescentes, ressupinadas, pediceladas, ecalcaradas; sépala dorsal oblanceolada, ca. $8 \times 2,5 \mathrm{~mm}$, ápice obtuso; sépalas laterais adnatas ao pé da coluna, ligeiramente coalescentes e infladas na base, formando pequeno mento, oblanceoladas, falcadas, ca. $11 \times 2,5 \mathrm{~mm}$, ápice obtuso; pétalas aderidas à sépala dorsal, estreito-oblanceoladas, falcadas, ca. 7,5 × $1 \mathrm{~mm}$, ápice obtuso; labelo unguiculado, dividido em hipoquílio e epiquílio, âmbito oblongo, ca. $9 \times 4 \mathrm{~mm}$, par de glândulas nectaríferas em aurículas, na base do labelo; hipoquílio oblongo, ca. $5 \times 2 \mathrm{~mm}$, margens inteiras, aderidas ao ginostêmio; epiquílio suborbicular, ca. $4 \times 4 \mathrm{~mm}$, ápice truncado, margem levemente ondulada, a porção apical do epiquílio apresenta uma sutil constrição. Ginostêmio ca. $6 \mathrm{~mm}$ compr.; base projetada em pé, ca. $4 \mathrm{~mm}$ compr.; rostelo membranáceo; antera 
dorsal, ereta; grãos de pólen aglutinados em polínias. Polínias 2, farinosas, providas apenas de viscídio. Ovário + pedicelo ca. $1 \mathrm{~cm}$ compr., ovário piloso; zona de abscisão entre pedicelo e ovário ausente. Fruto não visto.

Material examinado: RPPN L.C. Tamasia - Gerdau/ Açominas, 30.VIII.2007, fl., I.F. Braga (VIC).

Sauroglossum elatum é conhecida para a Colômbia, Ecuador, Brasil e norte da Argentina (Govaerts et al. 2015). No Brasil, possui registros para os estados da Bahia, Goiás e das regiões Sudeste e Sul, além do Distrito Federal (BFG 2015). Na SOB foi coletada em Floresta Estacional Semidecidual, na RPPN da Gerdau/Açominas, no sopé da porção sudoeste da serra. Foi encontrada florida em agosto. Difere das demais espécies na SOB pelo hábito terrícola, folhas bem desenvolvidas (ca. 30-36 cm compr.), oblanceoladas, apresentando base longamente atenuada, com inflorescências também bem desenvolvidas (ca. 1 m compr.). As flores são alvo-esverdeadas e o labelo é inteiro.

Há um erro de identificação comumente encontrado nos herbários, principalmente do Sul e Sudeste brasileiros, em que espécimes de S. elatum são identificados como $S$. nitidum (Vell.) Schltr., provavelmente relacionado ao fato de Pabts \& Dungs (1975) terem reconhecido $S$. nitidum como a única espécie do gênero para o país. Esse nome foi originalmente descrito pelo Padre José M.C. Velloso, na "Flora Fluminensis", como Serapias nitida Vell. e, posteriormente, transferido para Sauroglossum por Schlechter (1920). Recentemente, Fraga et al. (2015) elucidaram que a espécie originalmente descrita por Velloso na realidade pertence ao gênero Buchtienia Schltr. Dessa maneira, S. elatum é uma espécie bem distribuída, principalmente, pelas regiões Sul e Sudeste, enquanto B. nitida (Vell.) Fraga \& Meneguzzo é, por hora, tratada como uma espécie endêmica do sul do Rio de Janeiro. Morfologicamente estas duas espécies podem ser distinguidas pelo ápice das pétalas (obtuso em $S$. elatum e apiculado em $B$. nitida) e forma do labelo (inteiro em $S$. elatum e trilobado em B. nitida).

\section{Skeptrostachys Garay}

33.1. Skeptrostachys balanophorostachya (Rchb.f. \& Warm.) Garay, Bot. Mus. Leafl. 28: 359. 1982.

Fig. 8n

Terrícola, 26-48 cm alt. Crescimento simpodial. Raízes tuberiformes, estipitadas. Rizoma inconspícuo. Caule não intumecido em pseudobulbo. Folhas alternas, espiraladas, as da base suberetas, tornando-se eretas e imbricadas ao longo do caule, membranáceas, verdes, lanceoladas a oblanceoladas, 5-13 × 1,6-3 cm, base atenuada, amplexicaule, ápice obtuso a agudo. Inflorescência terminal, em espiga, muito congesta, levemente pubescente, multiflora; pedúnculo 1,5-2,5 cm compr.; brácteas do pedúnculo amplectivas, imbricadas, lanceoladas, 3,2-3,5 ×0,8-1,2 cm, ápice acuminado; raque $10-17,5 \mathrm{~cm}$ compr.; brácteas florais lanceoladas, 1,6-3,2 ×0,4-0,8 cm, ápice acuminado. Flores alvo-esverdeadas, ligeiramente pubescentes, ressupinadas, sésseis, ecalcaradas; sépala dorsal lanceolada, 9-12 × 3-4 mm, ápice obtuso; sépalas laterais adnatas ao pé da coluna, coalescentes e infladas na base, formando pequeno mento, lanceoladas, levemente falcadas, $10-12 \times 3-4 \mathrm{~mm}$, ápice obtuso; pétalas aderidas à sépala dorsal, lanceoladas a ovadas, 9-11 × $4 \mathrm{~mm}$, ápice obtuso; labelo unguiculado, subtrilobado âmbito ovado, 9-10 × 5-6 mm, par de glândulas na base, no contato entre os lobos laterais e o unguículo; lobos laterais semi-orbiculares, $2 \times 3-4$ $\mathrm{mm}$, ápice arredondado, margens inteiras, aderidas ao ginostêmio; lobo mediano oblongo, 3-4 × 2-3,5 $\mathrm{mm}$, ápice arredondado, margem levemente ondulada. Ginostêmio 3-4 mm compr., base projetada em pé de ca. $3 \mathrm{~mm}$ compr.; rostelo rígido; antera dorsal, ereta; grãos de pólen aglutinados em polínias. Polínias 2, farinosas, providas apenas de viscídio. Ovário 6-9 mm compr., piloso. Fruto não visto.

Material examinado: Sine loco, 15.V.1988, fl., M.V. Coimbra 12916(BHCB); 26.III.2003, fl., G.E. Valente et al. 1236 (VIC); Área 2, 28.III.2003, fl., C.C. de Paula et al. 716 (VIC); Sine loco, 23.IV.2005, fl., G.E. Valente 1731 (VIC).

Skeptrostachys balanophorostachya é conhecida para o Brasil e Paraguai (Govaerts et al. 2015). No Brasil distribui-se nos estados do Mato Grosso e das regiões Sudeste (exceto Espírito Santo) e Sul (BFG 2015). Na SOB foi coletada em campo limpo e campo rupestre. Floresce entre março e maio. Pode ser diferenciada das demais espécies de Spiranthinae na SOB pela presença de folhas durante a antese, inflorescência em espiga, muito congesta, na qual as brácteas geralmente ultrapassam em comprimento as flores, além de labelo com unguículo largo e um par de glândulas nectaríferas pilosas próximo às margens.

\section{Stigmatosema Garay}

34.1. Stigmatosema polyaden (Vell.) Garay, Bot. Mus. Leafl. 28(4): 377. $1982 . \quad$ Fig. 8o

Terrícola, ca. $50 \mathrm{~cm}$ alt. Crescimento simpodial. Raízes tuberiformes. Rizoma inconspícuo. Caule inconspícuo, não intumescido em pseudobulbo. Folhas rosuladas, suberetas na base, tornando-se encurvadas próximo ao ápice, membranáceas, 
verdes, variegadas, lâmina ovada a largo-elíptica, ligeiramente assimétrica, 5-5,5 × 3,1-3,6 cm, ápice obtuso a acuminado; pecíolo $5-6 \mathrm{~cm}$ compr. Inflorescência terminal, em racemo, laxa, pubescente na $1 / 2$ superior, multiflora; pedúnculo 34-38 cm compr.; brácteas do pedúnculo amplectivas, eretas, estreito-elípticas a lanceoladas, $2,5-5 \times 0,3-0,7 \mathrm{~cm}$, ápice agudo; raque 8,5-12 cm compr.; brácteas florais lanceoladas a lineares, 8-16 $\times$ 0,5-2,5 mm, ápice longamente acuminado. Flores alvo-esverdeadas, ressupinadas, pediceladas, ecalcaradas; sépala dorsal ovada, 5-6 ×2-2,5 mm, ápice acuminado; sépalas laterais pilosas na região proximal, ligeiramente coalescentes e infladas na base, formando pequeno mento, oblongas, ca. $6 \times 2$ $\mathrm{mm}$, ápice obtuso; pétalas aderidas à sépala dorsal, oblanceoladas, ligeiramente falcadas, ca. $5 \times 1,5$ $\mathrm{mm}$, ápice obtuso; labelo unguiculado, dividido em hipoquílio e epiquílio, âmbito oblongo, 5-6 × 3-4 $\mathrm{mm}$, par de glândulas nectaríferas em aurículas, na base do labelo; hipoquílio oblongo, 2,5-3 $\times$ 3-4 mm, margens inteira, aderidas ao ginostêmio; epiquílio unguiculado, transversalmente elíptico, 1,5 × 3-4 mm, ápice truncado, margem inteira, apresentando duas pequenas máculas castanhas. Ginostêmio 3-4 mm compr., base projetada em pequeno pé de ca. 1,5 mm compr.; rostelo membranáceo; antera dorsal, ereta; grãos de pólen aglutinados em polínias. Polínias 2, farinosas, providas apenas de viscídio. Ovário + pedicelo 6-8 mm compr.; ovário piloso; zona de abscisão entre pedicelo e ovário ausente. Fruto não visto.

Material examinado: Sine loco, 28.IX.2012, fl., M. Sobral et al. 14997 (HUFSJ); Sopé da serra, na porção sudeste, 29.I.2015, fl. cult. VIII.2015, T.L. Vieira 247 (SP).

Stigmatosema polyaden é conhecida para o Brasil, nos estados das regiões Sudeste e Sul, além do Distrito Federal (BFG 2015) e, aparentemente, também para a Bolívia (Tropicos 2015). Na SOB foi encontrada em Floresta Estacional Semidecidual, no sopé da porção sudeste da serra. Pode ser diferenciada das demais espécies na SOB, pelo hábito terrícola, folhas dispostas em roseta, pecioladas, e lâmina foliar ligeiramente assimétrica, além das flores externamente pilosas, com sépalas verdes e labelo alvo, com duas pequenas máculas castanhas.

\section{Veyretia Sclach.}

35.1. Veyretia rupicola (Garay) F.Barros, Hoehnea 30: 183. 2003.

Fig. 8p

Terrícola, 22-32,5 cm alt. Crescimento simpodial. Raízes tuberiformes. Rizoma inconspícuo. Caule não intumecido em pseudobulbo, insconspícuo. Folhas não vistas, ausentes durante a floração. Inflorescência terminal, em racemo, subcongesta, pilosa, 4-7-flora; pedúnculo 18,5-28,5 cm compr.; brácteas do pedúnculo amplectivas, laxas, eretas, oblanceoladas, 2,5-3,5 ×0,4-0,5 cm, ápice agudo; raque 2,2-2,7 cm compr.; brácteas florais ovadas a lanceoladas, $1-1,9 \times 0,3-0,5 \mathrm{~cm}$, ápice longamente acuminado. Flores alvo-esverdeadas, externamente pubescentes, ressupinadas, pediceladas, ecalcaradas; sépala dorsal oblongolanceolada, com constrição na porção mediana, ca. $10 \times 3 \mathrm{~mm}$, ápice arredondado; sépalas laterais adnatas ao pé da coluna, coalescentes até ca. 1/2 do seu comprimento, formando mento alongado, oblongo-lanceoladas, falcadas, 15-20 $\times$ 2-2,5 mm, ápice agudo, assimétrico; pétalas aderidas à sépala dorsal, âmbito oblanceolado, com constrição próximo ao ápice, falcadas, ca. 8 $\times 2 \mathrm{~mm}$, ápice arredondado; labelo unguiculado, dividido em hipoquilo e epiquilo, âmbito oblongo a estreito-elíptico, 12-15 × 4,5 mm, par de aurículas digitiformes na base do labelo, paralelas ao unguículo; par de glândulas nectaríferas pubescentes ausente na base; hipoquilo oblongooblanceolado, 9-11 × 4,5 mm, margens inteiras, aderidas ao ginostêmio, região apical apresenta calosidade em forma de "v" que se projeta para o epiquilo; epiquilo unguiculado, suborbicular, 2,53×3-3,5 mm, ápice arredondado, margem inteira. Ginostêmio 5-6 mm compr., base projetada em pé de 9-10 mm compr.; rostelo membranáceo, laminar; antera dorsal, ereta; grãos de pólen aglutinados em polínias. Polínias 2, farinosas, providas apenas de viscídio. Ovário + pedicelo 9-11 mm compr., glabro; zona de abscisão entre pedicelo e ovário ausente. Fruto não visto.

Material examinado: Sine loco, 18.IX.1990, fl., R.J.V. Alves \& J. Becker 1518 (RB); Área 2, 21.IX.2002, fl., C.C. de Paula et al. 311 (VIC).

Veyretia rupicola é endêmica do Brasil, com distribuição conhecida para os estados da Bahia, Goiás, Minas Gerais, São Paulo e Sergipe, além do Distrito Federal (Barros et al. 2015). Na SOB foi encontrada em campo limpo e campo rupestre, florescendo em setembro. Difere das demais espécies de Spiranthinae na SOB pelas sépalas laterais muito mais longas que a dorsal, coalescentes entre si até cerca de metade do seu comprimento, formando um mento alongado, pouco conspícuo, e mais ou menos imerso no ovário, de modo que pode ser tomado por parte deste. 
36. Zygopetalum Hook.

36.1. Zygopetalum maculatum (Kunth) Garay, Orquideología 5: 189. $1970 . \quad$ Fig. 8q

Terrícola ou saxícola, ca. $90 \mathrm{~cm}$ alt. Crescimento simpodial. Raízes filiformes, cobertas por velame. Rizoma insconspícuo. Cauloma intumescido em pseudobulbo. Pseudobulbo heteroblástico, oblongo-ovoide, não formando ângulos em seção transversal, ca. $4 \mathrm{~cm}$ compr., 3-6-foliado, coberto por bainhas. Folhas no ápice do pseudobulbo, suberetas, plicadas, cartáceas, verdes, oblongo-elípticas a elíptico-lanceoladas, $17-38,5 \times 1,8-2,8 \mathrm{~cm}$, sésseis, ápice agudo, base longamente atenuada. Inflorescência lateral, em racemo, laxa, 6-7-flora; pedúnculo ca. 63 $\mathrm{cm}$ compr.; brácteas do pedúnculo amplectivas, eretas a subpatentes, ovadas a estreito-ovadas, 2,5-3 $\times 1,7-2 \mathrm{~cm}$, ápice obtuso a agudo; raque $18,5-25 \mathrm{~cm}$ compr.; brácteas florais estreitoovadas a elíptico-lanceoladas, $1,9-4 \times 1-1,8$ $\mathrm{cm}$, ápice agudo. Flores com colorido complexo, ressupinadas, pediceladas, ecalcaradas; sépala dorsal verde, maculada de castanho-vináceo, ovado-lanceolada, 2,5-2,6 × 1-1,1 cm, ápice acuminado; sépalas laterais verdes maculadas de castanho-vináceo, livres, lanceoladas, levemente falcadas, 2,8-3 × 1-1,2 cm, ápice agudo; pétalas verdes maculadas de castanho-vináceo, elípticas, 2,4-2,5 × 0,9-1 cm, ápice agudo; labelo alvo maculado de lilás, unguiculado, articulado com o pé da coluna, inteiro, depressamente obovado a subreniforme, 3-3,7 × 3-3,6 cm, ápice emarginado, margem ondulada; calo formado por lamelas longitudinais na região basal, próximo ao unguículo. Ginostêmio 1,3-1,4 cm compr., base projetada formando pé de 5-7 $\mathrm{mm}$ compr., piloso; grãos de pólen aglutinados em polínias. Polínias 4 , em dois pares subiguais, maciças, providas de estipe e viscídio. Ovário + pedicelo 1,8-3,3 cm compr. Fruto não visto.

Material examinado: Sine loco, 14.V.1988, f1., M.V. Coimbra (BHCB 13084).

Material adicional examinado: BRASIL. MINAS GERAIS: Caeté, Serra da Piedade, 28.VII.1933, fl., Mello Barreto 4896 (SP).

Zygopetalum maculatum é conhecido para o norte do Peru e o leste do Brasil, onde ocorre nos estados da Bahia e das regiões Sudeste e Sul (BFG 2015; Govaerts et al. 2015). Nos dados do espécime examinado consta que foi coletado na SOB em mata, sem maiores detalhes de habitat. Foi encontrada florida no mês maio. Diferencia-se de K. eburnea (a outra espécie da subtribo Zygopetalinae na SOB) pelas flores relativamente grandes, com sépalas e pétalas verdes, maculadas de castanho-vináceo e labelo alvo, com máculas lilases, inteiro, depressamente obovado a suborbicular. Forma um complexo com Z. intermedium Lodd. ex Lindl., cuja delimitação não é muito clara, com distribuição geográfica sobreposta. Zygopetalum intermedium tem sido considerado sinônimo de Z. maculatum (Govaerts et al. 2015).

\section{Materiais excluídos do}

tratamento taxonômico

\section{Brassavola sp.}

No herbário RB foi encontrado um exemplar identificado como Scuticaria hadwenii (Lindl.) Planch. (R.J.V. Alves 4262), que, apesar do grau de deterioração, foi possível atribuí-lo ao gênero Brassavola R.Br., grupos estes vegetativamente semelhantes. Embora tenha sido possível esta correção, a inexistência de dados para a identificação da espécie nos fez optar por tratar o exemplar nesta seção e não descrevê-lo junto aos demais.

\section{Bifrenaria sp.}

Alguns espécimes de Bifrenaria foram encontrados durante as expedições de campo, embora nunca floridos. Também no Orquidário do Instituto de Botânica, os indivíduos não floriram até o preparo deste trabalho (código da coleção: P6696, P6697, P6698 e P6699). Aparentemente, todos são indivíduos de B. tyrianthina (Lodd.) Rchb.f., ocorrendo exclusivamente em campo rupestre, com hábito rupícola e morfologia vegetativa similar à deste táxon: pseudobulbos amarelados, bem desenvolvidos, angulados, com folhas elípticas.

\section{Cyrtopodium sp.}

Espécimes estéreis de Cyrtopodium foram encontrados na porção oeste da SOB e mantidos em cultivo no Orquidário do Instituto de Botânica, mas, até o presente momento, não apresentaram floração (código da coleção: P6772, P6773, P6775 e P6825). Nos herbários visitados também foram encontrados dois materiais do gênero, apenas com frutos: V.C. Souza et al. 7950 (ESA) e J.M. Fernandes et al. 667 (VIC). Aparentemente todos os exemplares pertencem à mesma espécie, já que todos apresentam inflorescência curta $(43-53 \mathrm{~cm}$ compr.) e ocorrem em solos arenoso-pedregosos, com frutos entre fevereiro e março. Todavia, diante 
da impossibilidade de identificar precisamente os materiais, optamos por tratá-los nesta seção.

\section{Habenaria sp.}

O material C.C. de Paula et al. 732 (VIC) possui apenas um fragmento do caule do que, possivelmente, é de um espécime de Habenaria. Esta hipótese é reforçada pelo que consta na etiqueta da exsicata, na qual a planta é descrita como terrícola, ocorrendo em campo graminoide, raízes tuberosas, sépalas e pétalas verde-claras e calcar protegido pela bráctea floral, com a flor lembrando uma aranha. Consta, ainda, na exsicata a seguinte frase escrita a lápis: "Infl. p/ desenhar". De qualquer forma, além do fragmento do caule com parte de algumas folhas, nada do que está descrito no rótulo encontra-se na exsicata, de modo que optamos por trazer essas informações e tratar este material nesta seção.

\section{Agradecimentos}

Os autores agradecem à FAPESP, a bolsa de Mestrado concedida ao primeiro autor; ao Prof. Dr. Cláudio Coelho de Paula, o convite ao segundo autor para realização desta flora; ao Instituto Estadual de Florestas de Minas Gerais (IEF-MG), a licença de coleta e todo suporte logístico durante as expedições de campo, em especial ao escritório de Ouro Branco; a Letícia Dornelas Moraes, gestora do Parque Estadual da Serra do Ouro Branco, e Cássio, guia de campo; aos curadores dos herbários visitados, a solicitude e empréstimos concedidos. Os autores também agradecem a João Aguiar Nogueira Batista, a discussão e auxílio na identificação das Habenaria e fotografias cedidas, e a Climbiê Ferreira Hall, o auxílio com os desenhos dos periantos dissecados. O segundo autor agradece ao $\mathrm{CNPq}$, a bolsa de Produtividade em Pesquisa concedida (Proc. 304506/2013-3).

\section{Referências}

Abreu, N.L.; Menini Neto, L. \& Konno, T.U. 2011. Orchidaceae das Serras Negra e do Funil, Rio Preto, Minas Gerais, e similaridade florística entre formações campestres e florestais do Brasil. Acta Botanica Brasilica 25: 58-70.

Alvares, C.A.; Stape, J.L.; Sentelhas, P.C.; Gonçalves, J.L.M. \& Sparovek, G. 2013. Köppen's climate classification map for Brazil. Metereologische Zeitschrift 22: 711-728.

Alves, R.J.V. 1990. The Orchidaceae of Itacolomi State Park in Minas Gerais, Brazil. Acta Botanica Brasilica 4: 65-72.
Alves, R.J.V. \& Kolbek, J. 2009. Summit vascular flora of Serra de São José, Minas Gerais, Brazil. Checklist 5: 35-73.

Azevedo, C.O. \& Van Den Berg, C. 2007. A família Orchidaceae no Parque Municipal de Mucugê, Bahia, Brasil. Hoehnea 34: 1-47.

Azevedo, U.R. 2007. Patrimônio geológico e geoconservação no Quadrilátero Ferrífero, Minas Gerais: potencial para a criação de um geoparque da UNESCO. Tese de Doutorado. Universidade Federal de Ouro Preto, Ouro Preto. 211p.

Barros, F. 1987. Orchidaceae. In: Giulietti, A.M.; Menezes, N.L.; Pirani, J.R.; Meguro, M. \& Wanderley, M.G.L. Flora da Serra do Cipó, Minas Gerais: caracterização e lista de espécies. Boletim de Botânica da Universidade de São Paulo 9: 1-151.

Barros, F. \& Pinheiro, F. 2004. Flora de Grão-Mogol, Minas Gerais: Orchidaceae. Boletim de Botânica da Universidade de São Paulo 22: 361-383.

BFG. 2015. Growing knowledge: an overview of seed plant diversity in Brazil. Rodriguésia 66: 1085-1113.

Bastos, C.A \& Van den Berg, C. 2012. A família Orchidaceae no município de Morro do Chapéu, Bahia, Brasil. Rodriguésia 63: 883-927.

Batista, J.A.N.; Bianchetti, L.B.; Nogueira, R.E.; Pelizzaro, K.F. \& Ferreira, F.E. 2004. The genus Habenaria (Orchidaceae) in the Itacolomi State Park, Minas Gerais, Brazil. Sitientibus série Ciências Biológicas 4: 25-36.

Batista, J.A.N. \& Bianchetti, L.B. 2010. Taxonomy, distribution and new taxa from the Habenaria crucifera (section Nudae, Orchidaceae) aggregate from Brazil and the Guianas. Brittonia 62: 57-79.

Batista, J.A.N.; Bianchetti, L.B.; González-Tamayo, R.; Figueroa, X.M.C. \& Cribb, P.J. 2011a. A synopsis of New World Habenaria (Orchidaceae) I. Harvard Papers in Botany 16: 1-47.

Batista, J.A.N.; Bianchetti, L.B.; González-Tamayo, R.; Figueroa, X.M.C. \& Cribb, P.J. 2011b. A synopsis of New World Habenaria (Orchidaceae) II. Harvard Papers in Botany 16: 233-273.

Campacci, M.A. \& Menini Neto, L. 2005. Uma nova espécie de orquidácea brasileira. Boletim CAOB 60: 123-127.

Campacci, M.A. 2006. Brasilidium. In: Docha-Neto, A.; Baptista, D.H, \& Campacci, M. Novos gêneros (baseados em Oncidium). Coletânea de Orquídeas Brasileiras 3: 77-81.

Chase, M.W.; Cameron, K.M.; Freudenstein, J.V.; Pridgeon, A.M.; Salazar, G.; Van den Berg, C. \& Schuiteman, A. 2015. An updated classification of Orchidaceae. Botanical Journal of the Linnean Society 177: 151-174.

Cogniaux, A. 1893-1896. Orchidaceae. In: Martius, C.F.P.; Eichler, A.G. \& Urban, I. (eds.). Flora brasiliensis. Frid. Fleischer, Lipsiae. Vol. 3, part 4, pp. 1-672. 
Cogniaux, A. 1898-1902. Orchidaceae. In: Martius, C.F.P., Eichler, A.G. \& Urban, I. (eds.). Flora brasiliensis. Frid. Fleischer, Lipsiae. Vol. 3, part 5, pp. 1-664.

Cogniaux, A. 1904-1906. Orchidaceae. In: Martius, C.F.P. \& Eichler, A.G. (eds.). Flora brasiliensis. Frid. Fleischer, Lipsiae. Vol. 3, part. 6, pp. 1-604.

Cribb, P.J. 1999. Classification. In: Pridgeon, A.M.; Cribb, P.J.; Chase, M.W. \& Rasmussen, F.N. (eds.). Genera Orchidacearum. Vol. 1. Oxford University Press, New York. 197p.

Dressler, R.L. 1981. The orchids: natural history and classification. Harvard University Press, Cambridge and London. 317p.

Dressler, R.L. 1993. Phylogeny and classification of the orchid family. Cambridge University Press, Melbourne. 314p.

Dressler, R.L. 2005. How many orchid species? Selbyana 26: $155-158$.

Fraga, C.N.; Meneguzzo, T.E.C. \& Saddi, E.M. 2015. The true identity of Serapias nitida, a species of Buchtienia (Orchidaceae) from Brazilian Atlantic Forest. Taxon 64: 335-361.

Fowlie, J.A. 1976. A revision of the section Crispum of the genus Oncidium. Orchid Digest 40: 1976.

Garay, L. 1980. A generic revision of the Spiranthinae. Botanical Museum Leaflets 28: 277-425.

Giulietti, A.M. \& Pirani, J.R. 1988. Patterns of geographic distribution of some plant species from the Espinhaço Range, Minas Gerais and Bahia, Brazil. In: Vanzolini, P.E. \& Heyer, W.R. (eds.). Proceedings of a Workshop on Neotropical Distribution Patterns. Academia Brasileira de Ciências, Rio de Janeiro. Pp. 39-69.

Govaerts, R.; Bernet, P; Kratochvil, K.; Gerlach, G.; Carr, G.; Alrich, P.; Pridgeon, A.M.; Pfahl, J.; Campacci, M.A.; Holland Baptista, D.; Tigges, H.; Shaw, J.; Cribb, P.; George, A.; Kreuz, K. \& Wood, J. 2015. World Checklist of Orchidaceae. Facilitated by the Royal Botanic Gardens, Kew. Disponível em $<$ http// apps.kew.org/wcsp/>. Acesso em 25 maio 2015.

Harley, R.M. \& Simmons, N.A. 1986. Florula of Mucugê, Chapada Diamantina, Bahia, Brazil. Royal Botanic Gardens, Kew. 238p.

Harley, R.M. 1995. Introducão. In: Stannard, B.L. (ed.) Flora of the Pico das Almas, Chapada Diamantina, Bahia, Brazil. Royal Botanic Gardens, Kew. Pp. 43-76.

Hatschbach, G.; Guarçoni, E.A.E.; Sartori, M.A. \& Ribas, O.S. 2006. Aspectos fisionômicos da vegetação da Serra do Cabral - Minas Gerais - Brasil. Boletim do Museu Botânico Municipal 67: 1-33.

Hoehne, F.C. 1940. In: Hoehne, F.C. (ed.). Flora Brasilica. São Paulo, Secretaria da Agricultura, Indústria e Comércio de São Paulo. Vol. 12, fasc. 1, pp. 1-254.
Hoehne, F.C. 1942. In: Hoehne, F.C. (ed.). Flora Brasilica. São Paulo, Secretaria da Agricultura, Indústria e Comércio de São Paulo. Vol. 12, fasc. 6, pp. 1-128.

Hoehne, F.C. 1945. In: Hoehne, F.C. (ed.). Flora Brasilica. São Paulo, Secretaria da Agricultura, Indústria e Comércio de São Paulo. Vol. 12, fasc. 2, pp. 1-389.

Hoehne, F.C. 1949. Iconografia das Orchidaceas do Brasil. Secretaria da Agricultura, São Paulo. 613p.

Kamino, L.H.Y.; Oliveira-Filho, A.T. \& Stehmann, J.R. 2008. Relações florísticas entre as fitofisionomias florestais da Cadeia do Espinhaço, Brasil. Megadiversidade 4: 39-49.

Leoni, L.S. \& Tinte, V.A. 2004. Flora do Parque Estadual da Serra do Brigadeiro, Minas Gerais, Brasil: caracterização da vegetação e lista preliminar das espécies. Fundação Faculdade de Filosofia, Ciências e Letras de Carangola, Carangola. 91p.

Longhi-Wagner, H.M. \& Araújo, A.C. 2014. Flora fanerogâmica da Serra do Ouro Branco, Minas Gerais: Cyperaceae. Rodriguésia 65: 369-404.

Luer, C.A. 1986. Icones Pleurothallidinarum III: Systematics of Pleurothallis. Monographs in Systematic Botanic from the Missouri Botanical Garden 20: 1-109.

Luer, C.A. 2006. Miscellaneous new taxa in the Pleurothallidinae. In: Luer, C.L. Icones Pleurothallidinarum XXVIII: a reconsideration of Masdevallia; systematics of Specklinia and vegetatively similar taxa. Monographs in Systematic Botanic from the Missouri Botanical Garden 105: 248.

Menini Neto, L.; Barros, F.; Vinhos, F.; Furtado, S.G.; Judice, D.M.; Fernandez, E.P.; Sfair, J.C.; Barros, F.S.M.; Prieto, P.V.; Kutschenko, D.C.; Moraes, M.A.; Zanata, M.R.V. \& Santos Filho, L.A. 2013. In: Martinelli, G. \& Moraes, M.A. (eds.). Livro vermelho da flora do Brasil. Instituto de Pesquisas Jardim Botânico do Rio de Janeiro, Rio de Janeiro. Pp. 749-818.

Melo, M.C. \& Borba, E.L. 2011. Morphological variability in rupicolous species of the Acianthera prolifera complex (Orchidaceae) ocurring in southeastern Brazil. Plant Systematics and Evolution 293: 135-145.

Melo, M.C.; Taucce, P.P.G. \& Borba. E.L. 2011. Reproductive biology and isolation mechanisms in rupicolous species of the Acianthera prolifera complex (Orchidaceae) occurring in southeastern Brazil. Plant Systematics and Evolution 293: 161-176.

Menini Neto, L.; Alves, R.J.V.; Barros, F. \& Forzza, R.C. 2007. Orchidaceae do Parque Estadual de Ibitipoca, MG, Brasil. Acta Botanica Brasilica 21: 687-696.

Mota, R.C. 2006. Orchidaceae na Serra do Caraça, Minas Gerais: levantamento florístico com ênfase no estudo taxonômico da subfamília Epidendroideae. 
Dissertação de Mestrado. Universidade Federal de Minas Gerais, Belo Horizonte. 310p.

Pabst, G.F.J. \& Dungs, F. 1975. Orchidaceae Brasiliensis. Vol. 1. Brucke-Verlag Kurt Schmersow, Hildesheim. 408p.

Pabst, G.F.J. \& Dungs, F. 1977. Orchidaceae Brasiliensis. Vol. 2. Brucke-Verlag Kurt Schmersow, Hildesheim. 418p.

Pansarin, E.R. 2005. Sistemática filogenética e biologia floral de Pogoniinae sul-americanas, e revisão taxonômica e análise de ceras epicuticulares do gênero Cleistes Rich. ex Lindl. (Orchidaceae). Tese de Doutorado. Universidade Estadual de Campinas, Campinas. 195p.

Pansarin, E.R. \& Amaral, M.C.E. 2006. Biologia reprodutiva e polinização de duas espécies de Polystachya Hook. no Sudeste do Brasil: evidência de pseudocleistogamia em Polystachyeae (Orchidaceae). Revista Brasileira de Botânica 29: 423-432.

Paula, C.C; Silva, R.R. \& Oliveira, D.A.S. 2005. A Serra do Ouro Branco. Universidade Federal de Viçosa, Viçosa. 50p.

Pessoa, E.; Maciel, J.R. \& Alves, M. 2015. Campylocentrum brevifolium (Lindl.) E.M. Pessoa \& M.Alves, a neglected and critically endangered orchid from the Atlantic Forest of Brazil. Kew Bulletin 70: 43.

Pirani, J.R.; Giulietti, A.M.; Mello-Silva, R. \& Meguro, M. 1994. Checklist and patterns of geographic distribution of the vegetation of Serra do Ambrósio, Minas Gerais, Brazil. Revista Brasileira de Botânica 17: 133-147.

Pridgeon, A.M.; Cribb, P.J.; Chase, M.C. \& Rasmussen, F.N. 1999. Apostasioideae and Cypripedioideae. Genera Orchidacearum. Vol. 1. Oxford University Press, New York. 230p.

Pridgeon, A.M. \& Chase, M.W. 2001. A phylogenetic reclassification of Pleurothallidinae (Orchidaceae). Lindleyana 16: 235-271.

Pridgeon, A.M.; Cribb, P.J.; Chase, M.C. \& Rasmussen, F.N. 2001. Orchidoideae (Part 1). Genera Orchidacearum. Vol. 2. Oxford University Press, New York. 438p.

Pridgeon, A.M.; Cribb, P.J.; Chase, M.C. \& Rasmussen, F.N. 2003. Orchidoideae (Part 2) and Vanilloideae. Genera Orchidacearum. Vol. 3. Oxford University Press, New York. 378p.

Pridgeon, A.M.; Cribb, P.J.; Chase, M.C. \& Rasmussen, F.N. 2005. Epidendroideae (Part 1). Genera Orchidacearum. Vol. 4. Oxford University Press, New York. 696p.

Pridgeon, A.M.; Cribb, P.J.; Chase, M.C. \& Rasmussen, F.N. 2009. Epidendroideae (Part 2). Genera Orchidacearum. Vol. 5. Oxford University Press, New York. 612p.
Pridgeon, A.M.; Cribb, P.J.; Chase, M.C. \& Rasmussen, F.N. 2014. Epidendroideae (Part 3). Genera Orchidacearum. Vol. 6. Oxford University Press, New York. 576p.

Radford, A.E.; Dickison, W.C.; Massey, J.R. \& Bell, C.R. 1974. Vascular plant systematics. Harper \& Row Pub, New York. 891p.

Rapini, A.; Ribeiro, P.L.; Lambert, S. \& Pirani, J.R. 2008. A flora dos campos rupestres da Cadeia do Espinhaço. Megadiversidade 4: 15-23.

Rizzini, C.T. 1979. Tratado de fitogeografia do Brasil. HUCITEC/EDUSP, São Paulo. 374p.

Rodrigues, J.B. 1877. Genera et Species Orchidearum Novarum. Vol. 1. Typographia Nacional, Rio de Janeiro. 206p.

Rodrigues, J.B. 1882. Genera et Species Orchidearum Novarum. Vol. 2. Typographia Nacional, Rio de Janeiro. 295p.

Santos, M.F. \& Sano, P.T. 2012. Flora fanerogâmica da Serra do Ouro Branco, Minas Gerais: Myrtaceae. Rodriguésia 63: 1065-1083.

Schlechter, R. 1920. Versuch einer systematischen Neuordnung der Spiranthinae. Beihefte zum Botanischen Centralblatt 37: 317-454.

Smidt, E.C. 2007. Filogenia e revisão taxonômica de Bulbophyllum Thouars (Orchidaceae) ocorrentes no Neotrópico. Universidade Estadual de Feira de Santana, Feira de Santana. 346p.

Sprunger, S. (ed.). 1996. João Barbosa Rodrigues - Iconographie des orchidées du Brésil. The illustrations. Vol. 1. Friedrich Reinhardt Verlag, Basle. 540p.

Thiers, B. [continuamente atualizado]. Index Herbariorum: a global directory of public herbaria and associated staff. New York Botanical Garden's Virtual Herbarium. Disponível em $<$ http://sweetgum.nybg.org/ih/>. Acesso em 12 junho 2015.

Toscano de Brito, A.L.V. 1995. Orchidaceae. In: Stannard, B.L. (ed.). Flora of the Pico das Almas: Chapada Diamantina, Bahia, Brazil. Royal Botanic Gardens, Kew. Pp. 725-767.

Toscano de Brito, A.L.V. 1998a. Orchidaceae (Morro do Pai Inácio). In: Guedes, M.L.S. \& Orge, M.D. (eds.). Checklist das espécies vasculares do Morro do Pai Inácio (Palmeiras) e Serra da Chapadinha (Lençóis), Chapada Diamantina, Bahia, Brasil. Universidade Federal da Bahia, Salvador. Pp. 33.

Toscano de Brito, A.L.V. 1998b. Orchidaceae (Serra da Chapadinha). In: Guedes, M.L.S. \& Orge, M.D. (eds.). Checklist das espécies vasculares do Morro do Pai Inácio (Palmeiras) e Serra da Chapadinha (Lençóis), Chapada Diamantina, Bahia, Brasil. Universidade Federal da Bahia, Salvador. Pp. 53-54. 
Toscano de Brito, A.L.V. \& Queiroz, L.P. 2003. Orchidaceae. In: Zappi, D.C.; Lucas, E; Stannard, B.L; Lughadha, E.N.; Pirani, J.R.; Queiroz, L.P.; Atkins, S.; Hind, D.J.N.; Giulietti, A.M.; Harley, R.M. \& Carvalho, A.M. (eds.). Lista das plantas vasculares de Catolés, Chapada Diamantina, Bahia, Brasil. Boletim de Botânica da Universidade de São Paulo. 21: 396-397.

Toscano de Brito, A.L.V. \& Cribb, P. 2005. Orquídeas da Chapada Diamantina. Nova Fronteira, Rio de Janeiro. 399 p.

Tropicos 2015. Tropicos.org. Missouri Botanical Garden. Disponível em <http://www.tropicos.org $>$. Acesso em 25 maio 2015.
UNESCO. 2005. Latin America and the Caribbean: 122 biosphere reserves in 21 countries. Disponível em: $<$ http://www.unesco.org/new/en/natural-sciences/ environment/ecological-sciences/biosphere-reserves/ latin-america-and-the-caribbean/> . Acesso em 12 junho 2015.

Viana, P.L. \& Lombardi, J.A. 2007. Florística e caracterização dos campos rupestres sobre canga na Serra da Calçada, Minas Gerais, Brasil. Rodriguésia 58: 159-177.

Vieira, T.L.; Barros, F. \& Roque, N. 2014. A família Orchidaceae no muncípio de Jacobina, estado da Bahia, Brasil. Hoehnea 41: 469-482. 